\title{
Pacific Northwest Laboratory Annual Report for 1986 to the DOE Office of Energy Research
}

Part 2 Environmental Sciences

September 1987

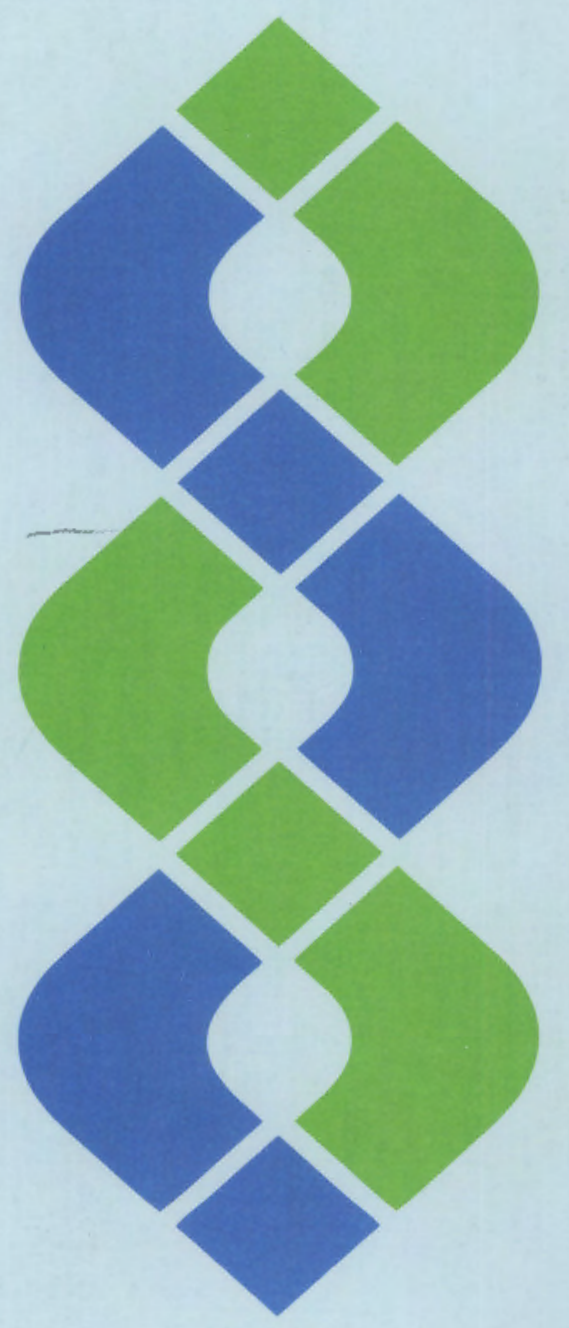

Prepared for the U.S. Department of Energy under Contract DE-AC06-76RLO 1830

Pacific Northwest Laboratory Operated for the U.S. Department of Energy by Battelle Memorial Institute

\section{ํㅏㅅ Baltelle}




\section{DISCLAIMER}

This report was prepared as an account of work sponsored by an agency of the United States Government. Neither the United States Government nor any agency thereof, nor Battelle Memorial Institute, nor any of their employees, makes any warranty, expressed or implied, or assumes any legal liability or responsibility for the accuracy, completeness, or usefulness of any information, apparatus, product, or process disclosed, or represents that its use would not infringe privately owned rights. Reference herein to any specific commercial product, process, or service by trade name, trademark, manufacturer, or otherwise, does not necessarily constitute or imply its endorsement, recommendation, or favoring by the United States Government of any agency thereof, or Battelle Mernorial Institute. The views and opinions of authors expressed herein do not necessarly state or reflect those of the United States Government or any agency thereof, or Battelle Memorial Institute.

\section{PACIFIC NORTHWEST LABORATORY operated by \\ BATTELLE MEMORIAL INSTITUTE for the UNITED STATES DEPARTMENT OF ENERGY under Contract DE-AC06-76RLO 1830}

\begin{tabular}{|c|c|}
\hline \multicolumn{2}{|c|}{ Printed in the United States of America } \\
\hline \multicolumn{2}{|c|}{ Available from } \\
\hline \multirow{3}{*}{\multicolumn{2}{|c|}{$\begin{array}{c}\text { National Technical Information Service } \\
\text { United States Department of Commerce } \\
5285 \text { Port Royal Road } \\
\text { Springfield, Virginia } 22161\end{array}$}} \\
\hline & \\
\hline & \\
\hline \multirow{2}{*}{\multicolumn{2}{|c|}{$\begin{array}{l}\text { NTIS Price Codes } \\
\text { Microfiche A01 }\end{array}$}} \\
\hline & \\
\hline \multicolumn{2}{|c|}{ Printed Copy } \\
\hline & Price \\
\hline Pages & Codes \\
\hline $001-025$ & $\mathrm{~A} 02$ \\
\hline $026-050$ & $\mathrm{A03}$ \\
\hline $051-075$ & $\mathrm{~A} 04$ \\
\hline $076-100$ & A05 \\
\hline $101-125$ & $\mathrm{~A} 06$ \\
\hline $126-150$ & A07 \\
\hline $151-175$ & A08 \\
\hline $176-200$ & A09 \\
\hline $201-225$ & $\mathrm{~A} 010$ \\
\hline $226-250$ & A011 \\
\hline $251-275$ & $\mathrm{~A} 012$ \\
\hline $276-300$ & A013 \\
\hline
\end{tabular}




\section{Pacific Northwest Laboratory Annual Report for 1985 to the DOE Office of Energy Research}

\section{Part 2 Environmental Sciences}

Staff Members

of Pacific Northwest Laboratory

September 1987

Prepared for

the U. S. Department of Energy

under Contract DE-AC06-76RLO 1830

Pacific Northwest Laboratory

Richland, Washington 99352 
. 


\section{PREFACE}

This 1986 annual report from Pacific Northwest Laboratory (PNL) to the Department of Energy (DOE) describes research in environment, health, and safety conducted during fiscal year 1986. The report again consists of five parts, each in a separate volume.

The five parts of the report are oriented to particular segments of our program. Parts 1 to 4 report on research performed for the DOE Office of Health and Environmental Research in the Office of Energy Research. Part 5 reports progress on all research performed for the Assistant Secretary for Environment, Safety and Health. In some instances, the volumes report on research funded by other DOE components or by other governmental entities under interagency agreements. Each part consists of project reports authored by scientists from several PNL research departments, reflecting the multidisciplinary nature of the research effort.

The parts of the 1986 Annual Report are:

Part 1: Biomedical Sciences

Program Manager - J. F. Park

D. L. Felton, Report Coordinator and Editor

Part 2: Environmental Sciences

Program Manager - R. E. Wildung

R. E. Wildung, Report Coordinator

K. A. Borgeson and

S. G. Weiss, Editors

Part 3: Atmospheric Sciences

Program Manager - C. E. Elderkin $\quad$ C. E. Elderkin, Report Coordinator

E. L. Owczarski, Editor

Part 4: Physical Sciences

Program Manager - L. H. Toburen $\quad$ L. H. Toburen, Report Coordinator

P. L. Gurwell, Editor

Part 5: Nuclear and Operational Safety

Program Managers - L. G. Faust

L. G. Faust, Report Coordinator

W. E. Kennedy, Jr. S. K. Ennor, Editor

J. M. Selby

B. L. Steelman

Activities of the scientists whose work is described in this annual report are broader in scope than the articles indicate. PNL staff have responded to numerous requests from DOE during the year for planning, for service on various task groups, and for special assistance.

A major effort was in response to OHER's request for assistance in collecting information on the release of radioactivity from the nuclear power plant accident at Chernobyl. Environmental and chemical scientists participated in collecting and analyzing atmospheric and environmental samples in Sweden, over the Pacific Ocean, along the northwest coast of North America and along the path of the radioactive plume as it passed across the United States.

Credit for this annual report goes to the many scientists who performed the research and wrote the individual project reports, to the program managers who directed the research and coordinated the technical progress reports, to the editors who edited the individual project reports and assembled the five parts, and to Ray Baalman, editor in chief, who directed the total effort. 
Members of the Scientific Advisory Committee established last year are:
Dr. Franklin I. Badgley
Dr. Leo K. Bustad
Dr. Franklin Hutchinson
Dr. Albert W. Johnson
Dr. J. Newell Stannard

University of Washington
Washington State University
Yale University
San Diego State University
University of Rochester
University of California, San Diego

W. J. Bair, Manager

S. Marks, Associate Manager

Environment, Health and Safety

Research Program

Previous reports in this series:

\section{Annual Report for}

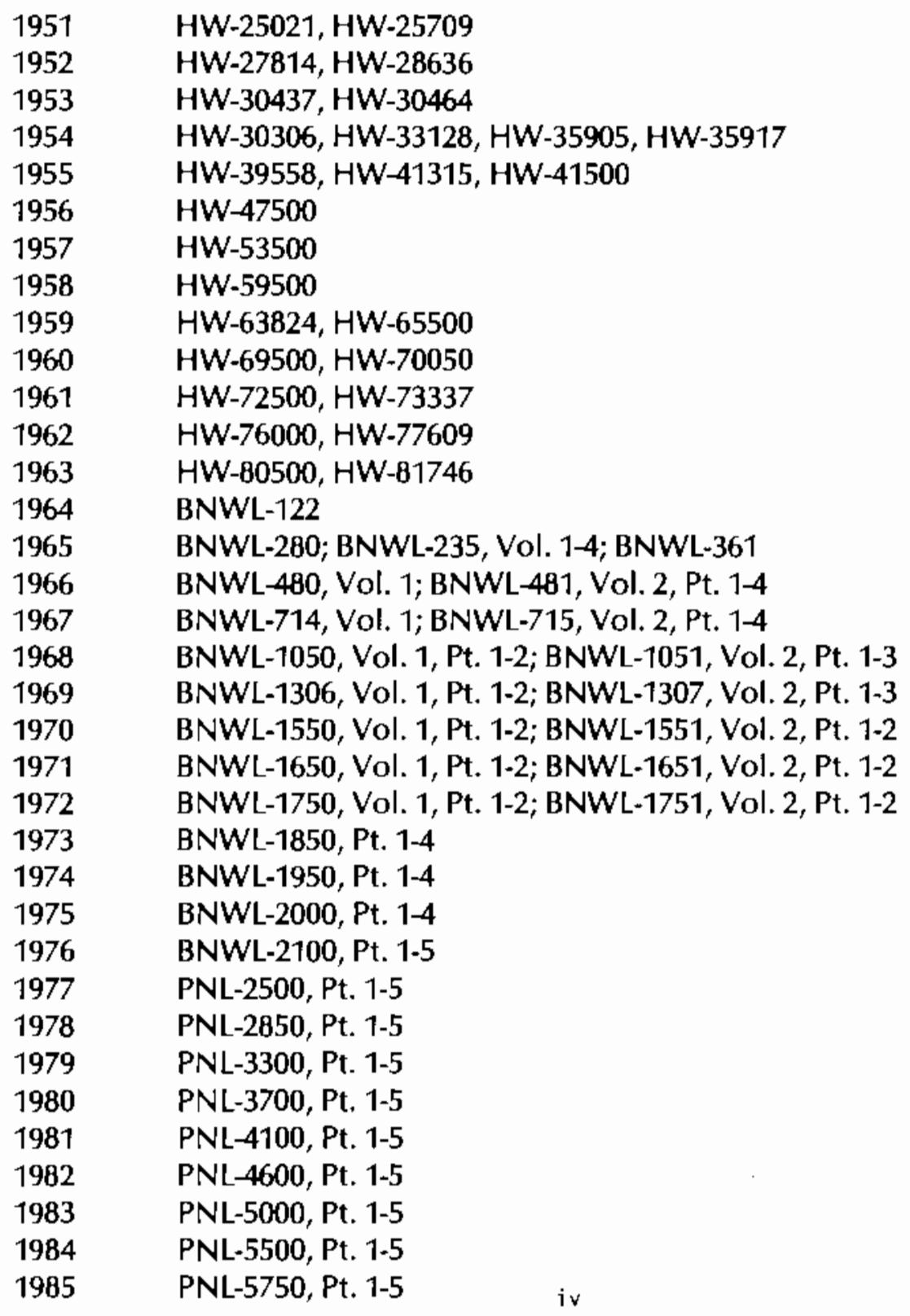

HW-25021, HW-25709

HW-27814, HW-28636

HW-30437, HW-30464

HW-30306, HW-33128, HW-35905, HW-35917

HW-39558, HW-41315, HW-41500

HW-47500

HW-53500

HW-59500

HW-63824, HW-65500

HW-69500, HW-70050

HW-72500, HW-73337

HW-76000, HW-77609

HW-80500, HW-81746

BNWL-122

BNWL-280; BNWL-235, Vol. 1-4; BNWL-361

BNWL-480, Vol. 1; BNWL-481, Vol. 2, Pt. 1-4

BNWL-714, Vol. 1; BNWL-715, Vol. 2, Pt. 1-4

BNWL-1050, Vol. 1, Pt. 1-2; BNWL-1051, Vol. 2, Pt. 1-3

BNWL-1306, Vol. 1, Pt. 1-2; BNWL-1307, Vol. 2, Pt. 1-3

BNWL-1550, Vol. 1, Pt. 1-2; BNWL-1551, Vol. 2, Pt. 1-2

BNWL-1650, Vol. 1, Pt. 1-2; BNWL-1651, Vol. 2, Pt. 1-2

BNWL-1750, Vol. 1, Pt. 1-2; BNWL-1751, Vol. 2, Pt. 1-2

BNWL-1850, Pt. 1-4

BNWL-1950, Pt. 1-4

BNWL-2000, Pt. 1-4

BNWL-2100, Pt. 1-5

PNL-2500, Pt. 1-5

PNL-2850, Pt. 1-5

PNL-3300, Pt. 1-5

PNL-3700, Pt, 1-5

PNL-4100, Pt. 1-5

PNL-4600, Pt. 1-5

PNL-5000, Pt. 1-5

PNL-5500, Pt. 1-5

PNL-5750, Pt. 1-5 


\section{FOREWORD}

This report summarizes progress in environmental sciences research conducted by Pacific Northwest Laboratory (PNL) for the Office of Health and Environmental Research in FY 1986. The past year has been one of transition and achievement. The Laboratory implemented the second phase of a reorganization designed to improve disciplinary alignment and renew its commitment to scientific quality. A cohesive program plan developed to guide the OHER Environmental Sciences Research program has also been implemented to meet refined objectives. Research is directed toward developing a fundamental understanding of the key processes controlling the long-term fate and biological effects of fugitive chemicals and other stresses resulting from energy development.

The program is focused on terrestrial, subsurface, and coastal marine systems, and this research forms the basis, in conjunction with remote sensing, for definition and quantification of processes leading to impacts at the global level. The plan entails building on PNL technical strengths in biogeochemistry, hydrodynamics, molecular biology, and quantitative ecology. These strengths are applied in multidisciplinary programs to probe basic relationships. Unique intermediate-scale experimental systems are employed for examination of arid land watershed dynamics, aerosol behavior and effects, and multidimensional subsurface transport. Advanced field laboratories (National Environmental Research Park and the Marine Research Laboratory) are used in conjunction with remote sensing to validate concepts and models and extrapolate results to the system and global levels. Strong university liaisons now in existence are being markedly expanded to form consortia for efficient use of PNL laboratory and field resources and the specialized technical capabilities in the university community.

This report is organized to reflect the new programmatic structure. Sections are devoted to Detection and Management of Change in Terrestrial Systems, Biogeochemical Phenomena, Subsurface Microbiology and Transport, Marine Sciences, and Theoretical (Quantitative) Ecology. Emphasis has been placed on vertical integration of research, utilizing the basic results of disciplinary research at the chemical, molecular, and cellular levels to aid in understanding observations of these processes at the field and ecosystem levels. This approach has already resulted in significant advances in our understanding of the complex relationships governing the effects of energy development within a global context.

A volume synthesizing the results of 30 years of research at PNL in Terrestrial Ecosystems has been completed and the results used to conceptualize and plan future research. The recently completed Arid Land Watershed Facility has been used to test hypotheses on the relationships between plant processes and water balance and extending, by the use of remote sensing, these results to the regional and global scales. Investigation into the interactions between biological and geochemical processes has demonstrated the importance of key organic acids and peptides in the complexation and transport of elements in plants and root zones, forming the basis for new advances in understanding the role of the rhizosphere in biogeochemical cycles.

The Subsurface Transport Program has played a major national role in the early stages of an exciting new endeavor to investigate the previously unexplored subsurface ecosystem. PNL research has shown that organisms in the deep subsurface possess diverse capabilities 
to degrade organic contaminants and carry plasmids that reflect their stressed environment and that offer new possibilities for aquifer restoration through genetic technology. Concurrently, investigations of mineral surface-water interactions in the subsurface have advanced our understanding of electrostatic and hydrophobic reactions for multiple organic contaminants and the importance of steric effects in sorption processes.

Marine studies directed toward understanding the molecular, biochemical, cellular, and organismic responses to environmental effects have identified initial relationships between certain diseases and environmental stress, which should be amenable to examination of unique gene transcripts controlling the expression of stress-related proteins.

Finally, in the Theoretical (Quantitative) Ecology Program, new statistical approaches have been developed from standard experimental theory, as well as other fields such as geostatistics, providing more precise methods for sampling and experimental design in areas of mobile wildlife populations, hazardous wastes, and subsurface microbiology.

Research in the environmental sciences is in an exciting and challenging new phase, and the PNL research program is now positioned to make major contributions to the resolution of important national environmental problems.

Raymond E. Wildung

Subprogram Manager

Environmental Sciences 


\section{CONTENTS}

PREFACE $\ldots \ldots \ldots \ldots \ldots \ldots \ldots \ldots \ldots \ldots \ldots \ldots \ldots \ldots \ldots \ldots \ldots \ldots \ldots \ldots \ldots \ldots \ldots \ldots$

FOREWORD $\ldots \ldots \ldots \ldots \ldots \ldots \ldots \ldots \ldots \ldots \ldots \ldots \ldots \ldots \ldots \ldots \ldots \ldots \ldots$

Detecting and Managing Change in Terrestrial Ecosystems

Dynamics of Arid Land Ecosystems

The Effect of Natural Disturbance on Vegetation and Soil Moisture in the Shrub-Steppe,

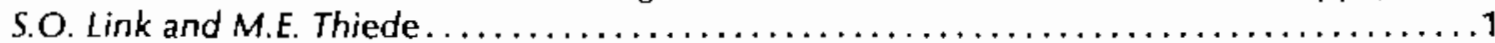

Remote Sensing (Reflex): Measuring Bidirectional Reflectance for Vegetation

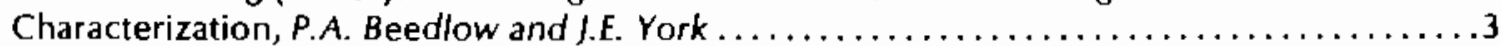

Biotic Transport Processes in Arid Ecosystems, L.L. Cadwell . . . . . . . . . . . . . . . .

Installation of Precision-Weighing Lysimeters for Evapotranspiration Measurements

at Hanford's Arid Land Ecology Reserve, $G, W$. Gee $\ldots \ldots \ldots \ldots \ldots \ldots \ldots \ldots \ldots \ldots$

National Environmental Research Park, W.H. Rickard $\ldots \ldots \ldots \ldots \ldots \ldots \ldots \ldots$

Biogeochemical Phenomena

Soil and Plant Processes Controlling Cation Behavior in Terrestrial Systems,

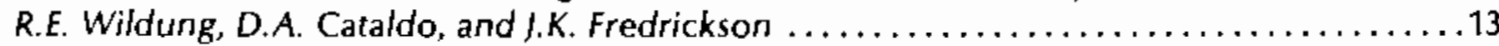

Environmental Behavior of Inorganic Anions, T.R. Garland, D.A. Cataldo,

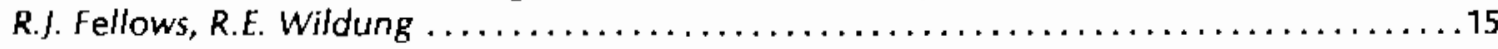

Soil/Plant Behavior of Organic Xenobiotics, D. A. Cataldo, R.J. Fellows, and R.M. Bean .....17

Subsurface Transport

Subsurface Chemistry of Organic Compounds, J.M. Zachara and C.C. Ainsworth . . . . ...21

Subsurface Microbial Phenomena, J.K. Fredrickson and R.J. Hicks . . . . . . . . . . . . . . . 24

Fluid Dynamics in Subsurface Systems, C.S. Simmons, G.P. Streile, J.F. McBride,

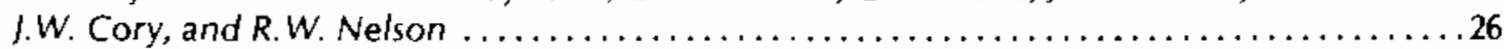

Marine Sciences

Marine Chemistry of Energy-Related Contaminants, E. A. Crecelius and J.S. Young . . . . . 29

Environmental Stress and Disease in Marine Animals, R.A. Elston . . . . . . . . . . . . . 31

Theoretical (Quantitative) Ecology

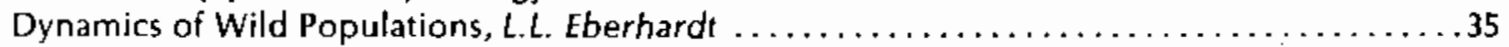

Quantifying Energy-Related Effects on Mobile Species, J.R. Skalski, M.A. Simmons,

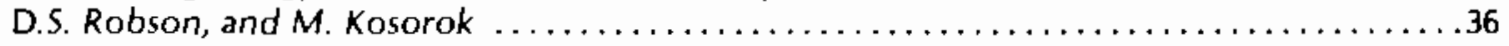

Designs for Environmental Field Studies, J.M. Thomas and L.L. Eberhardt ............38

University Interactions

National Environmental Research Park $\ldots \ldots \ldots \ldots \ldots \ldots \ldots \ldots \ldots \ldots \ldots \ldots \ldots \ldots \ldots \ldots \ldots$

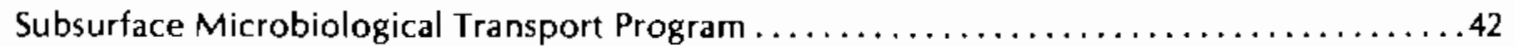

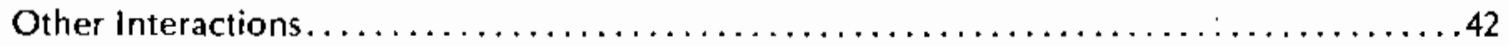

Technology Transfer

Detecting and Managing Change in Terrestrial Ecosystems $\ldots \ldots \ldots \ldots \ldots \ldots \ldots \ldots \ldots$

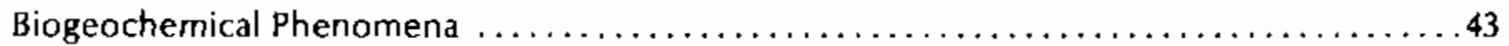




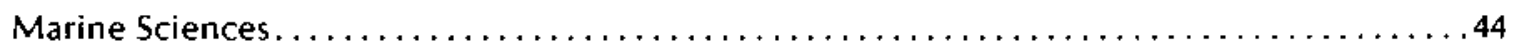

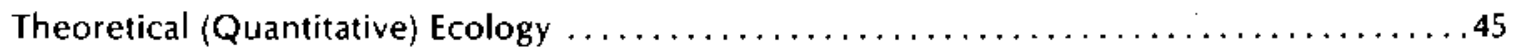

Exploratory Research

Detection of Genetically Engineered Microorganisms, J.K. Fredrickson . . . . . . . . . .44

Remote Aerosol Measurement for Wind Tunnel Tests, M.W. Ligotke . . . . . . . . . . . .47

Remotely Acquired Thermal Data for Energy Exchange in Arid Regions,

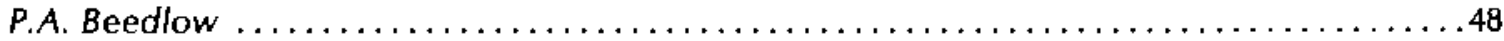

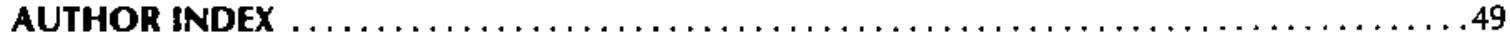

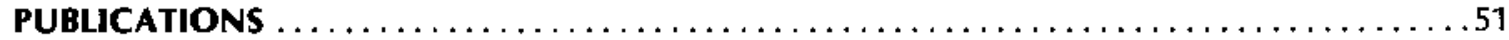

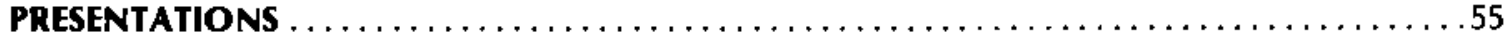

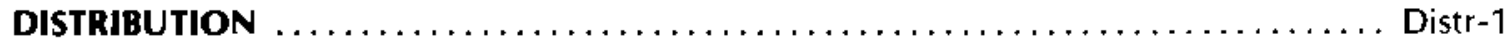


Detecting and
Managing Change in
Terrestrial Ecosystems 


\section{- Detecting and Managing Change in Terrestrial Ecosystems}

Until recently, few techniques existed for detecting long-term synoptic changes of the physical, chemical, and biologic processes occurring in the atmosphere, at the surface of the earth, and below the ground. Instrumentation is now available that can selectively provide these measurements. In addition, numerical models and artificial intelligence programs are being developed to interface between these newly acquired data sets. Such techniques significantly increase our potential for understanding terrestrial systems in ways and over time and space scales not previously possible.

During FY 1986, high priority was placed on initiating new research to provide simultaneous observations of major arid land processes. As part of this effort a Watershed Research Facility was constructed on the Arid Land Ecology Reserve, which is a part of the Hanford National Environmental Research Park (NERP). This facility is comprised of a set of precision-weighing lysimeters to provide information on soil-water dynamics and energy balance parameters; an irrigation system and series of field manipulation plots to study the interrelationships between mineral dynamics, microbial ecology, and plant growth parameters; and a series of microwatersheds and a rainfall simulator for identifying the influence of biota on nearsurface water balance and the resulting transport pararneters. As part of the Remote Fluvial Experiments (REFLEX) program, heat and water balance processes associated with arid land watersheds are being related to remotely acquired data sets in initial investigations to extrapolate our understanding of these processes to the regional and global scales.

The NERP concept provides the long-term protection, continuity, and organizational structure that is imperative for these studies of natural systems; it also provides the necessary institutional structure for faculty and student participation from the broader academic community.

\section{DYNAMICS OF ARID LAND ECOSYSTEMS}

A variety of land disturbances and other stresses are associated with energy development and production activities. Arid lands are highly sensitive to stress and often recover at rates that are slow compared to those of more mesic areas. The research described here is designed to provide new methods for the early detection of energyrelated stress and to evaluate the ultimate impact of reduced productivity or increased transport of chemical contaminants within arid lands.

THE EFFECT OF NATURAL DISTURBANCE ON VEGETATION AND SOIL MOISTURE IN THE SHRUBSTEPPE

S. 0. Link and M. E. Thiede

To predict the effects of disturbance in terrestrial systems, it is necessary to understand the relationship between yearly soilwater extraction patterns and plant activity. Wildfires on the Arid Lands Ecology (ALE) Reserve during 1981 and 1984 have permitted PNL to examine the effect of temporary removal of surface vegetation on these relationships. Since the 1984 wildfire, plant growth has been monitored by sampling research plots for green leaf area and biomass. In addition, litter biomass has been determined to assess rate of biomass turnover.

In 1984, five research sites were selected to study the response of ecosystems to wildfire. The sites are different with respect to fire history, composition of the plant community, and microclimate. The 1984 Burn site is composed of herbaceous plants, of which bunchgrass (Agropyron spicatum) is the major species. The Sage site has not been burned recently and is composed of herbaceous and woody plants, of which sagebrush (Artenisia tridentata) is the major species. The 1981 Burn site is similar in composition to the bunchgrass site. The Upper Snively and Lower Snively sites are abandoned agricultural fields that were last used in the mid-1940s; both sites are now dominated by cheatgrass (Bromus tectorum). The Upper Snively site burned in 1984 and both sites burned in 1981. Upper Snively is at a higher elevation than the Lower Snively site and is wetter.

Leaf area results are presented in Table 1 , which shows comparisons between harvests taken in April and June. Leaf area decreased at all sites between April and June because of increasing water stress and genetically 
TABLE 1. Measurements of Total Green Leaf Area for Five Study Sites (measurements made in April and June 1986)

\begin{tabular}{|c|c|c|}
\hline \multirow[b]{2}{*}{ Sites } & \multicolumn{2}{|c|}{$\begin{array}{c}\text { Mean Leaf Area/ } \\
\text { Ground Area } \\
\left(\mathrm{m}^{2} \text { leaf } / \mathrm{m}^{2} \text { ground) }\right.\end{array}$} \\
\hline & April & June \\
\hline 1984 Burn & 0.22 & 0.19 \\
\hline Sage & 0.48 & 0.36 \\
\hline 1981 Burn & 0.27 & 0.22 \\
\hline Upper Snively & 0.60 & 0.21 \\
\hline Lower Snively & 0.28 & - \\
\hline
\end{tabular}

controlled phenology. The decrease was greatest at the Lower Snively site. Maximal leaf area was found at the Upper Snively site in April when the annual species were at their greatest vigor. Leaf area was similar at the 1981 and 1984 Burn sites, even though these sites were burned at different times. The greater leaf area at the Sage site relative to the 1981 and 1984 Burn sites resulted from the sagebrush contribution.

Biomass patterns (Table 2) were not consistently lower in June than they were in April, perhaps because of increasing leaf density. The biomass patterns at the 1981 and 1984 Burn and Sage sites were identical to the leaf area patterns. When compared to leaf area, the biomass of plants at the Snively sites was relatively less than that for plants at the other sites, suggesting that plants at the Snively sites are less dense.

Litter patterns (Table 3) were not time dependent. Litter biomass was greater at the Snively sites than at the other sites, perhaps because of the high turnover rate of the annual plants and low decomposition rates at the Snively sites. The effect of the 1984 fire on the Upper Snively site is apparent in the lower litter biomass at this site as

TABLE 2. Measurements of Total Green Biomass for Five Study Sites (measurements taken in April and June 1986)

\begin{tabular}{|c|c|c|}
\hline \multirow[b]{2}{*}{ Sites } & \multicolumn{2}{|c|}{ Mean Biomass $\left(\mathrm{g} / \mathrm{m}^{2}\right)$} \\
\hline & April & June \\
\hline 1984 Burn & 58 & 70 \\
\hline Sage & 118 & 100 \\
\hline 1981 Burn & 50 & 58 \\
\hline Upper Snively & 65 & 69 \\
\hline Lower Snively & 40 & - \\
\hline
\end{tabular}

TABLE 3. Measurements of Litter Biomass for Five Study Sites (measurements made in April and June 1986)

\begin{tabular}{|c|c|c|}
\hline \multirow[b]{2}{*}{ Sites } & \multicolumn{2}{|c|}{$\begin{array}{c}\text { Mean Litter } \\
\text { Biomass }\left(\mathrm{g} / \mathrm{m}^{2}\right)\end{array}$} \\
\hline & April & June \\
\hline 1984 Burn & 100 & 280 \\
\hline Sage & 290 & 250 \\
\hline 1981 Burn & 50 & 50 \\
\hline Upper Snively & 730 & 280 \\
\hline Lower Snively & 640 & 710 \\
\hline
\end{tabular}

compared to the Lower Snively site. Senescent bunchgrass may have contributed to the increase of litter biomass at the 1984 Burn site.

The size frequency distribution of sagebrush at the Sage site is presented in Figure 1. Most plants at this site are small. If this site can be assumed to be at steady state, the distribution implies that most of the plants do not survive to attain a large size or that the growth of the small plants is restricted because of competition with neighboring plants for water and nutrients.

Soil moisture storage since the fall of 1984 (the fire occurred in late summer 1984) is shown in Figure 2 for three depths at the

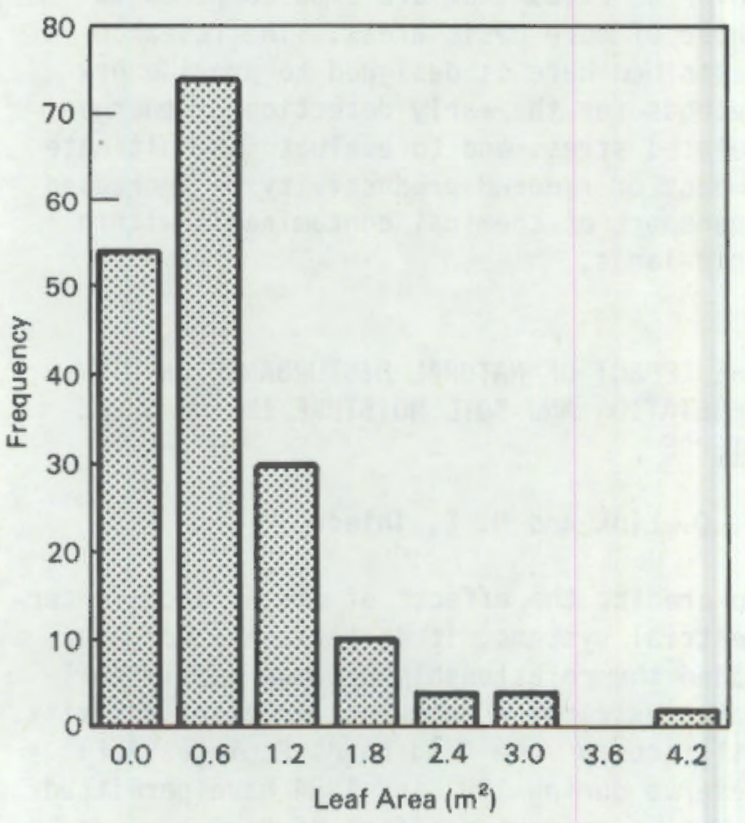

FIGURE 1. Size Frequency Distribution of Sagebrush at the Sage Site. 

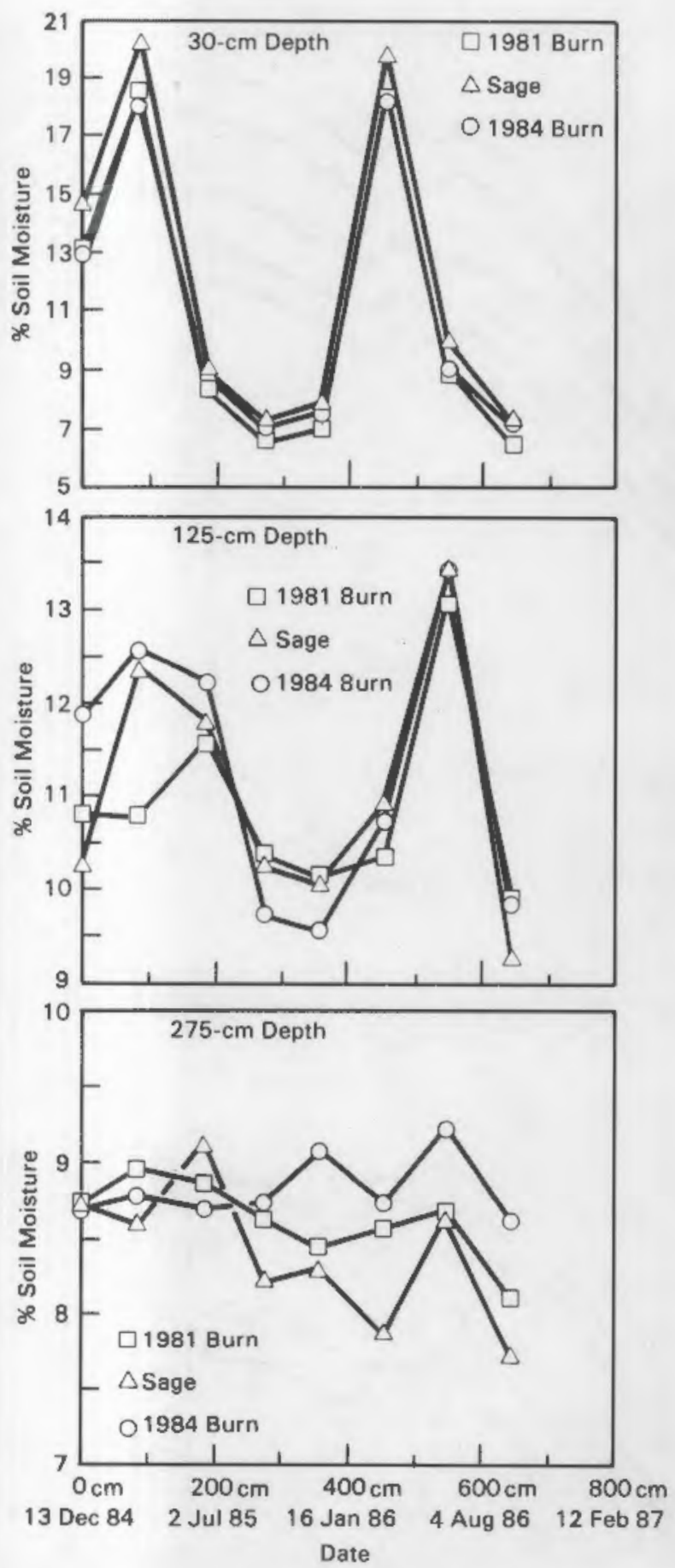

FIGURE 2. Soil Moisture Storage at Three of the Study Sites. Data are shown for $30 \mathrm{~cm}, 125 \mathrm{~cm}$, and $275 \mathrm{~cm}$.

1984 Burn, 1981 Burn, and the Sage sites. At $30 \mathrm{~cm}$, little difference in moisture storage was apparent from the onset of the study. At
$125 \mathrm{~cm}$, soil moisture differences were evident. The 1981 Burn site was distinctly drier during the winter and early summer, but after the first year the differences between the sites disappeared. At $275 \mathrm{~cm}$, moisture differences remain after 2 years. The 1984 Burn site is wettest, and the Sage site is driest. The data suggest that the presence of the deep-rooted sagebrush results in deep water extraction. During FY 1987 we will continue to observe the dynamics of plant and soil water characteristics as they relate to continuing recovery from fire disturbance.

REMOTE SENSING (REFLEX): MEASURING BIDIRECTIONAL REFLECTANCE FOR VEGETATION CHARACTERIZATION

P. A. Beedlow and J. E. York

Satellite, aircraft, and ground measurements of solar spectral reflectance have been routinely used to study land cover. The usefulness of these measurements are being extended at several test areas on the Hanford Site. In most studies that use spectral reflectance to differentiate land cover types, the reflectance is assumed to be Lambertian (i.e., equal in all directions). The reflectance of most land cover types is known to be nonLambertian, but the actual angular dependence is not well known. Measurements of bidirectional reflectance (reflectance as a function of the angle of reflection) may be useful in characterizing landscape units. Bidirectional reflectance may be affected by cover type, plant or soil structure, leaf area, biomass, and/or other environmental factors. Field data gathered from the Hanford Site with a portable spectroradiometer are being used to determine the effects and uses of bidirectional reflectance, particularly to evaluate its usefulness in determining biomass, leaf area, and soil properties for the characterization of landscape units.

Two examples of bidirectional reflectance spectra are presented. Reflectance was measured at five different angles from a sagebrush (Figure 1) and at 11 angles from a field of young oats. For oats (Figure 2), reflectance is higher at directions away from rather than toward the sun at small angles from vertical, but is higher looking toward the sun rather than away from the sun at 


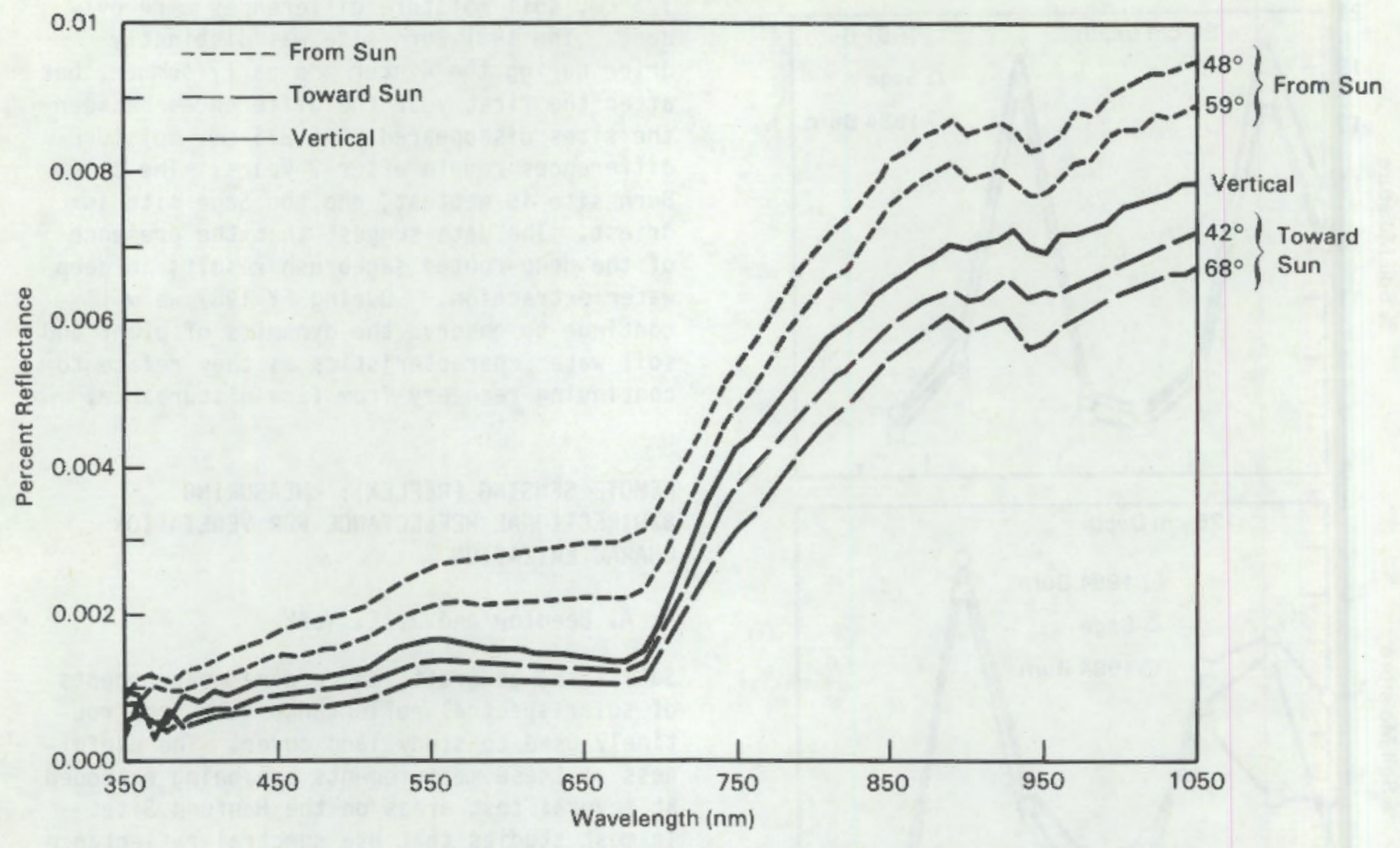

FIGURE 1. Solar Reflectance from a Sagebrush at Various Angles of Reflectance.

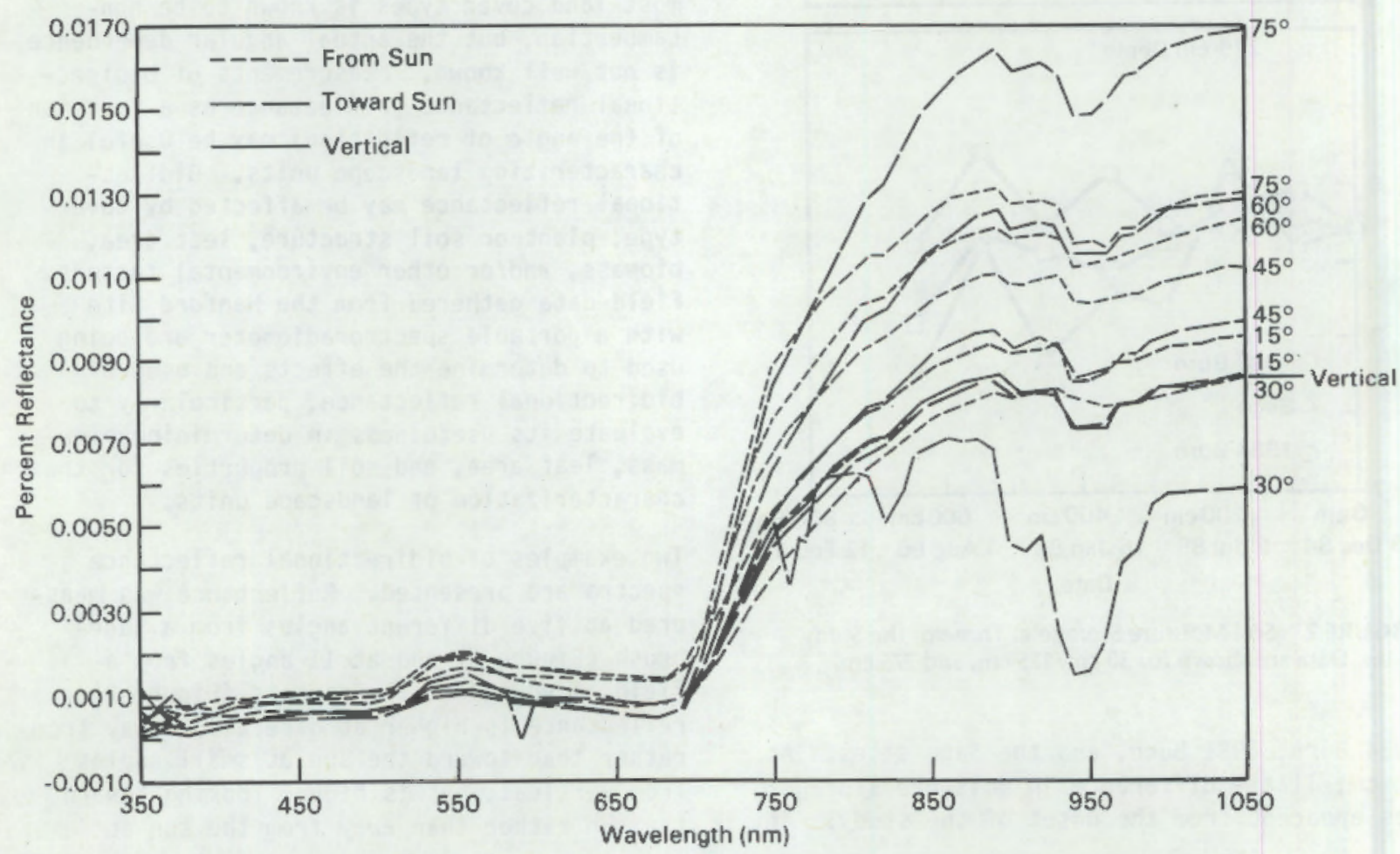

FIGURE 2. Solar Reflectance from a Field of Young Oats at Various Angles of Reflectance. 
large angles from vertical. The angle at which the crossover occurs and the differences in reflectance at given angles from vertical looking toward and away from the sun are likely related to physiological factors affecting the vegetation. This crossover phenomenon is not present in the sagebrush spectra (Figure 1), possibly because a large enough variation in angles was not measured. Measurements of bidirectional reflectance permit discrimination among land cover components not possible with conventional, vertical measurements and are being used to compile a reflectance data set for the Hanford environs. This data set will be used in research to find correlations between bidirectional reflectance and plant physiology. It will also serve as ground truth data for calibrating and interpreting satellite reflectance data.

\section{BIOTIC TRANSPORT PROCESSES IN ARID ECOSYSTEMS}

L. L. Cadwell

Landscapes in arid environments are sculptured, stabilized, and populated in response to the abundance, movement, and use of water. Water that reaches 1 and as precipitation may recharge the groundwater, contribute to surface water supplies, or return to the atmosphere during evapotranspiration. As water moves over and through surface soils it transports a host of environmentally important materials that include dissolved nutrients, organic matter, pollutants, and sediments. For any climate, local plant and animal populations exert a significant influence on surface water hydrology and associated material transport. This influence is particularly evident in arid climates where plants and animals process a significant fraction of the available water.

A research program is being developed at the Arid Land Ecology (ALE) Reserve on the Hanford Site to measure and model the hydrologic cycie response as it relates to plant and animal processes in a natural, semiarid environment. Simulated rainfall is being applied to study plots in the shrub-steppe to view response and measure transport parameters.

Related studies are being conducted at the Idaho National Engineering Laboratory (INEL.) and the Los Alamos Scientific Laboratory
(LASL), and during 1986 working relationships were established between these laboratories and PNL for the purpose of exchanging research approaches and results. The objective is to use current technology to investigate hydrologic and material transport response at a range of arid/semiarid sites that may be impacted by energy development.

The water balance/transport studies will be conducted using rainfall simulation--the technique of applying water to plots in a manner that simulates natural rainfall. A rainfall simulator creates an outdoor laboratory that can provide control over when, where, and how much rainfall is applied to a study plot, and allows data that might require years to collect under natural rainfall conditions to be collected in a very short time. The rotating-boom rainfall simulator acquired for use in this study was constructed for PNL by the U.S. Department of Agricuiture (USDA) Agricultural Research Service. By selecting the nozzle size, water pressure during application, and height of the boom above the plot surface, the impact of natural rainfall is simulated.

The common experimental design involves two vegetative treatments. One treatment consists of naturai vegetative cover and the second treatment includes clipped plots from which higher vegetation has been removed. The study plots were randomly selected from the total population of available sites and are located on uniform slopes that have approximately a $9 \%$ slope. Plots are paired such that one plot of each pair is clipped and the other is unclipped (Figure 1). Treatments are replicated four times and two additional plot pairs serve as natural rainfall controls. Two rainfall applications are being made annually, one prior to the growing season and one after. For each set of experiments the same rainfall simulation sequence is applied. A l-hr run (dry) is made under initially dry soil conditions. This run is followed 24 hr later by a 30 -min run (wet), which is followed $30 \mathrm{~min}$ later by another 30-min run (very wet). The simulator provides an intensity of $2.5 \mathrm{in./hr}$ for all runs.

The major accomplishments during FY 1986 involved planning and coordinating the research approach, acquiring and testing the rainfall simulator, and conducting initial rainfall 

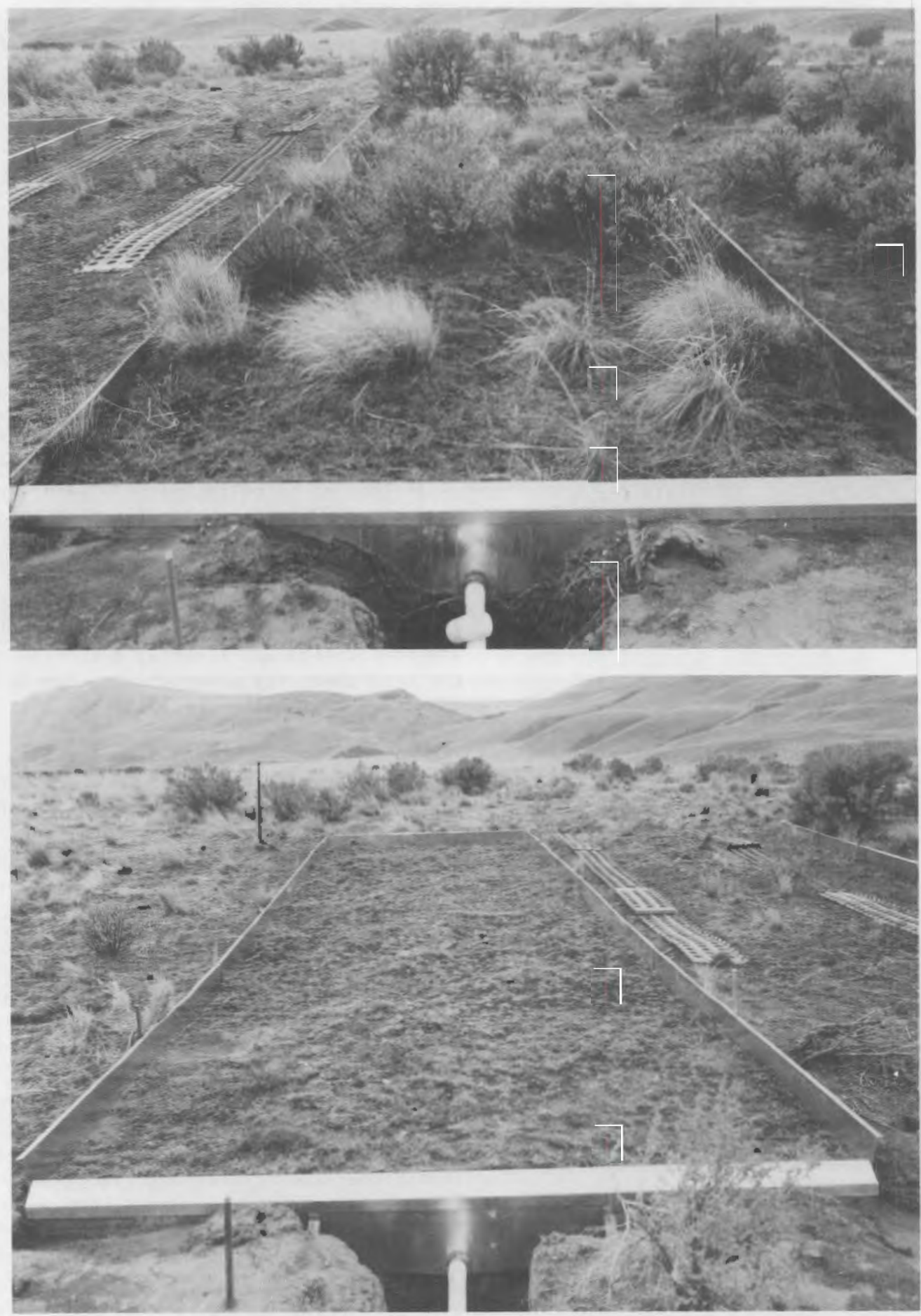

FIGURE 1. Example of Study Plots Used for Water Balance/Transport Studies

simulations. We also designed, characterized, and installed field test plots. The study site selected is located near Bobcat Canyon on the ALE Reserve and is part of the
Watershed Research facility. Related studies are colocated on the reserve to maximize our collective understanding of plant, animal, nutrient, water, and soil-related processes. 
Figures $2 \mathrm{a}$ and $2 \mathrm{~b}$ are hydrographs showing a sequence of three applications of simulated rainfall on a plot pair. The plot pair consists of one plot with native vegetation and one drastically disturbed plot (all vegetation clipped and removed). Both hydrographs show increasing peak runoff rates associated with wetter initial conditions. However, a comparison of runoff between plots (Figure $2 a$ versus Figure $2 b$ ) suggests an anomoly. Other factors being equal, the expected response to vegetation removal is an increase in runoff. However, runoff from each of the three applications on the vegetated plot is greater than from the nonvegetated plots. Examination of these plot surfaces during simulated rainfall suggests that surface characteristics in the shrub-steppe influencing runoff are highly

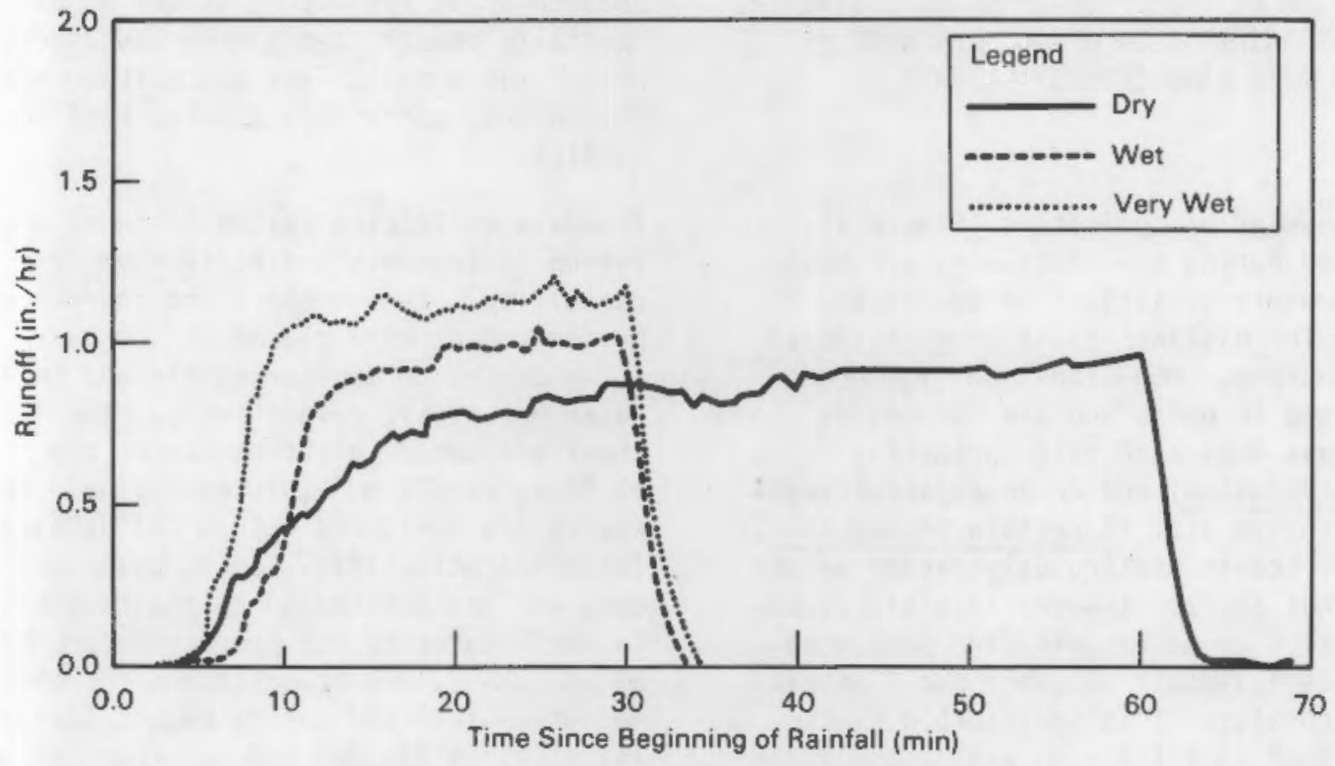

FIGURE 2a. Hydrograph Comparisons for Dry, Wet, and Very Wet Rainfall Applications on Natural Vegetation Plots

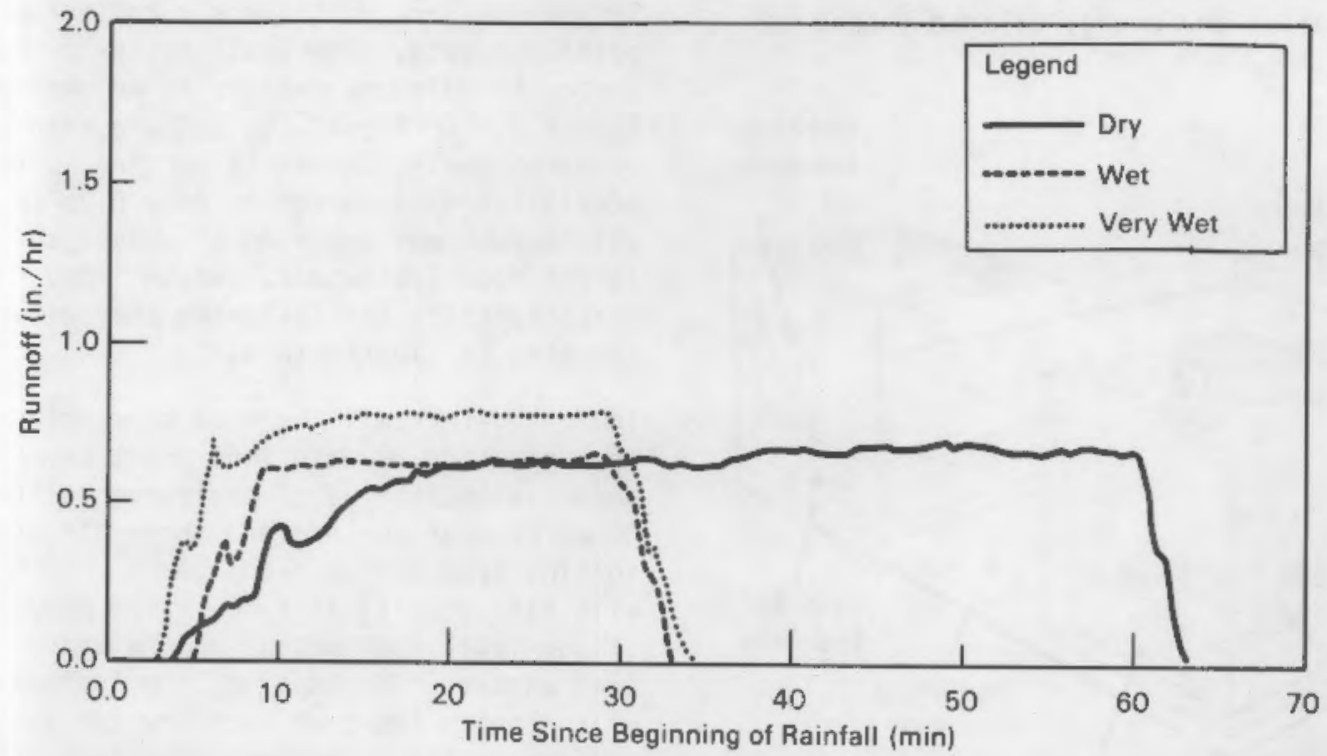

FIGURE 2b. Hydrograph Comparisons for Dry, Wet, and Very Wet Rainfall Applications on Plots with Vegetation Clipped and Removed 
variable, may exhibit distinct spatial patterns, and are likely to be the product of dynamic physical/biological interactions. These preliminary results suggest a need to examine spatial variability on a somewhat smaller scale in order to describe the fundamental processes affecting surface water redistribution in arid landscapes.

INSTALLATION OF PRECISION-WEIGHING LYSIMETERS FOR EVAPOTRANSPIRATION MEASUREMENTS AT HANFORD'S ARID LAND ECOLOGY RESERVE

\section{G. W. Gee}

Precision-weighing lysimeters (Figure 1), constructed during the past year, are being used to measure variations in evapotranspiration for distinct plant communities at the ALE Reserve. Monolith-type lysimeters are arranged in pairs and are located on a bunchgrass-dominated site (primarily Agropyron spicatum) and on an adjacent sagebrush-dominated site (Artemisia tridentata). Electronic scales continuously record weight changes that represent water loss via evapotranspiration or water gain from precipitation. Each lysimeter weighs about 7 metric tons and consists of an undisturbed block (monolith) of soil $1.5 \mathrm{~m}$ on a side and $1.7 \mathrm{~m}$ deep. As part of a comprehensive Watershed Research Facility on ALE, these unique lysimeters will provide information on soil water dynamics and energy balance needed to

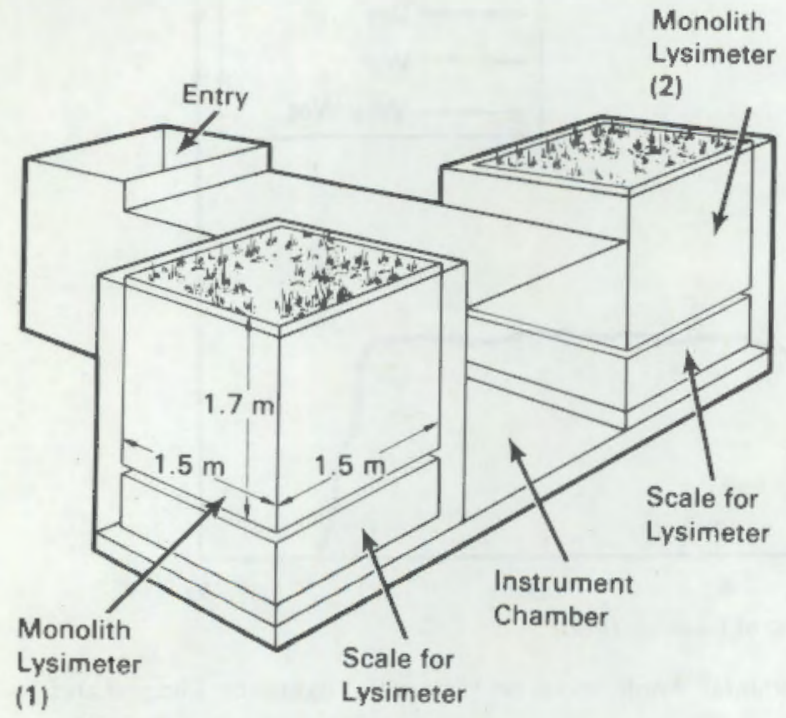

FIGURE 1. Lysimeter Facility at ALE. develop predictive models of the water-driven processes in arid regions.

The monolith soil is a silt loam (Xerollic Camborthid) with a hard, caliche (calcium carbonate) layer at about the $1 \mathrm{~m}$ depth. As the monolith was excavated, an open-ended steel container was dropped over the soil to contain the monolith. Two 20-ton hydraulic jacks attached to a flat steel plate were used to shear the bottom of the monolith. A specially constructed gantry was used to remove the monolith and place it on a soilfilled tray containing a network of ceramic candles.

The data collection system includes monitoring instruments and radiotelemetric capability. Tensiometers and thermocouple phychrometers were placed at the 0.7 - and 1.2-m depths to monitor matric and total water potential, respectively. The lysimeters are set on piatform scales that have a $\pm 0.05-\mathrm{kg}\left( \pm 0.02-\mathrm{mm} \mathrm{H}_{2} 0\right)$ resolution. The scales are monitored with a CR7 datalogger (Campbell Scientific, Logan, Utah) and the data are transmitted $40 \mathrm{~km}$ via radiotelemetry to the laboratory for processing and display on an IBM-PC. Instrumentation for micrometeorological and energy budget data will be installed in FY 1987 and incorporated with the data retrieval system.

Since coming online in mid-summer, the lysimeters have continuously collected water gain/loss data. The sensitivity of this system to moisture changes is demonstrated in Figure 2. On August 29, 1986, a rain event occurred during the early morning. Total precipitation amounted to only $0.25 \mathrm{~cm}$, but this amount was recorded as weight changes in all four lysimeters. Weight loss due to evapotranspiration following the rainy period can also be clearly seen.

The lysimeters will be used to model evapotranspiration of arid land plant communities under various types of environmental stress. of particular concern are those stresses resulting from energy development. Such models will fill a critical role in the management of low-level radioactive and hazardous chemical wastes. In addition, the lysimeters will provide the core facility for developing the capability to measure arid land energy balance from satellite platforms. 


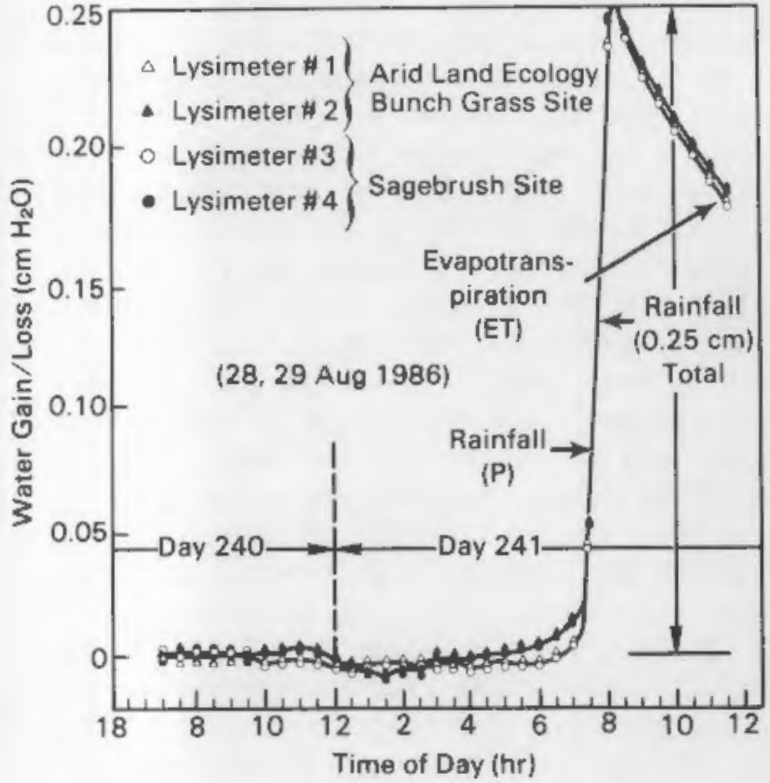

FIGURE 2. Lysimeter Water Gain/Loss $\left(\mathrm{cm} \mathrm{H}_{2} \mathrm{O}\right)$.

NATIONAL. ENVIRONMENTAL RESEARCH PARK

W. H. Rickard

The National Environmental Research Park at Hanford serves as an outdoor laboratory. It is a representative segment of the shrubsteppe ecosystem that occupies the semiarid intermountain region of the northwestern United States, east of the Cascades and generally west of the Rocky Mountains. For 40 years the $1400-\mathrm{km}^{2}$ Hanford Site has been free from the usual kinds of land use widely practiced in the shrub-steppe region (i.e., livestock grazing, cultivation for crops, and urbanization). Its use has been partially industrial with a few scattered industrial buildings. Most of the land plays a passive role as a health and security buffer zone. However, the unusually large area assigned to passive land use makes the land attractive for various kinds of basic ecological research both from the view of scientific abservations and descriptions as well as experimental manipulations and development of ecological monitoring methodology. The isolation and protection provided by the Hanford Site allows the long-tern preservation of "control" areas. In addition, the large land area allows for experimental manipulation in the absence of customary land use interferences.
Industrially Induced Cnemicals in the Park Environment

Various industrial processes result in the release of potentially toxic or cancerinducing chemicals to the surface environment. The biological accumulation of such chemicals is an important consideration in environmental monitoring programs world-wide. Most efforts to monitor the behavior of radionuclides result in information that can be used to estimate potential radiation doses to people. However, wild animals of ten have greater body burdens of radionuclides than do domestic animals or people. From the viewpoint of wildlife management, it is important to know if industrially produced toxic chemicals exist in the environment in quantities yreat enough to be deleterious to the health or reproductive performance of wild animals. It is also important to determine by environmental monitoring if body burdens of toxic materials are increasing or decreasing over time as the result of engineering modifications or improvements in industrial practices.

The amount of radioactive materials released into the Columbia River from various industrial processes on the Hanford Site has been greatly diminished since 1972, the year when all single-pass reactors were shut down. However, the continual operation of the $N$ Reactor results in the release of small amounts of ${ }^{90} \mathrm{Sr}$ into the Columbia River.

The Columbia River as it flows through the Hanford Site has historically been an important nesting area for a local population of Canada geeşe. It has been known for a long time that ${ }^{90} \mathrm{Sr}$ tends to accumulate in the bones of birds and mammals and in the calcareous egg shells of birds. Egg shells remain in goose nests when the goslings leave the nest. These shells can be collected from individual nests and chemically analyzed. Egg shells represent environinental materials that are ingested by parent geese, metabolized into body cells, and released as eggs. If the goose population is self-sustaining, the egg shells can be collected each year for monitoring purposes.

The Snake River is a large tributary of the Columbia River that joins the Columbia River 20 miles $(28 \mathrm{~km})$ downstream from the Hanford Site. This large river also supports a 
self-sustaining nesting population of Canada geese, but it does not have an industrial source of ${ }^{90} \mathrm{Sr}$ as does the Columbia River.

A comparison of the amounts of ${ }^{90} \mathrm{Sr}$ in goose egg shells collected from the Hanford Reach of the Columbia River and the Snake River in the spring of 1986 is shown below. The amounts are expressed as $\mathrm{pCi} / \mathrm{g}$ dry weight.

\begin{tabular}{|c|c|c|c|c|}
\hline Location & $n$ & $\begin{array}{c}\text { Arithmetic } \\
\text { mean }\end{array}$ & $\begin{array}{c}\text { Natural } \log \\
\text { mean }\end{array}$ & median \\
\hline $\begin{array}{l}\text { Hanford } \\
\text { Reach }\end{array}$ & 6 & 1.619 & 0.402 & 1.555 \\
\hline $\begin{array}{l}\text { Snake } \\
\text { River }\end{array}$ & 10 & 0.847 & -0.241 & 0.791 \\
\hline
\end{tabular}

$t=2.94, P=0.01$.

The samples from the Hanford Reach averaged twice as much ${ }^{90} \mathrm{Sr}$ as did samples from the Snake River. The ${ }^{90} \mathrm{Sr}$ measured in the egg shells from the Snake River is believed to be derived from worldwide fallout, while the Columbia River samples represent fallout plus a contribution from the industrial operations conducted on the Hanford Site.

The Columbia River population of Canada geese appears healthy and egg production and hatchability is comparable to other populations that have a similar record of study. However, graduate student research conducted on the Hanford Reach goose population indicates that gosling mortality is much higher here than that observed at other places in the United States. The nigh mortality is attributed to predation, although this has not been verified by actual observation.

Great blue herons living on the Hanford Environmental Park have been investigated as indicators of the availability of heavy metals in their foraging environment. Nesting herons feed mostly on live fish captured in the vicinity of their nest trees. Fish are brought to the nest to feed the young, who spend a month or more in the nest and are fed daily by their parents. The distances that parent birds travel each day to search for fish are still to be determined. The fecal material discharged from nests was collected from four locations in eastern Washington and chemically analyzed for metals. The fecal material was collected from locations along the Columbia River (Hanford Site), Benton County; Yakima River, Yakima County; Potholes Reservoir, Grant County; and Sylvan Lake, Lincoln County. Herons nesting along the Yakima River had greater concentrations of cobalt, lead, and copper in their feces than did the herons nesting at the other locations. Herons nesting along the Yakima and Columbia Rivers also had greater concentrations of metals in their feces than did those nesting near lakes. This suggests that industrial and urban discharges to these large rivers may be responsible for the greater levels of metals in herons foraging on riverine fish, as compared to the concentrations in herons nesting on freshwater lakes where historically there is little or no urban or industrial releases of metals. The use of nesting great blue herons appears to be a practical, nondestructive way to utilize resident wildlife in long-term environmental monitoring programs.

A Small-Scale Field Experiment Involving Two Research Parks

An important purpose of land classification schemes is to extrapolate environmental data obtained in one part of a region to another part with a reasonable degree of confidence. The National Environmental Research Parks, located in southeastern Idaho and on the Hanford Site in Washington, allow the following hypothesis to be tested: in land classified as shrub-steppe, essential trace element concentrations in the leaves of a dominant plant (sagebrush) are much alike even though sample stations are widely spaced geographically. In addition, artificially introduced trace elements added to the surface soil beneath the shrubs behave similarly, as is determined by measuring living leaves in subsequent growing seasons.

The major classification schemes that apply to the National Environmental Parks in Idaho and Washington are summarized below. The two parks differ in their geographic location and altitude. The Hanford Environmental Park is located in southeastern Washington at $1000 \mathrm{ft}$ above mean sea level, and the Idaho Park is located in southeastern Idaho at $4000 \mathrm{ft}$ above mean sea level. 
Classification
Schemes

\begin{tabular}{|c|c|c|}
\hline $\begin{array}{l}\text { Physiographic } \\
\text { province }\end{array}$ & Columbia Plateau & Same \\
\hline Climate & Semiarid & Same \\
\hline Soil group & Sierozem & Same \\
\hline $\begin{array}{l}\text { Vegetation } \\
\text { type }\end{array}$ & Shrub-steppe & Same \\
\hline Land use & Wildlife habitat & Same \\
\hline $\begin{array}{l}\text { Genome of } \\
\text { concern }\end{array}$ & $\frac{\frac{\text { Artemisia }}{\text { tridentata }}}{\text { (Sagebrush) }}$ & Same \\
\hline
\end{tabular}

The analytical results of the experiment are shown in Figure 1. Of the four micronutrients tested (copper, manganese, molybdenum, and zinc) only manganese concentrations show statistical differences between the two sites. Molybdenum added to soil greatly increased the molybdenum concentrations in sagebrush leaves at both sites. Manganese added to the soil increased the manganese concentrations in leaves at the Washington site only, and copper and zinc did not increase the leaf concentrations of these metals at either site. The behavior of manganese is closely related to processes affecting hydrous oxide formation and stability in soil. Explanation of these differences will, therefore, require more detailed mineralogical studies.

Although the research parks are widely separated geographically and differ greatly in a) titude and microclimate, sagebrush is the dominant plant at both parks. The concentration of essential micronutrient elements in sagebrush leaves was not greatly different at the two locations. Three of the four elements added to soil beneath sagebrush shrubs behaved similarly at both sites. Only manganese behaved differently, but the magnitude of the difference was not great.

of considerable interest in terms of the long-term effects of trace element influxes to soil are the differences between added and control systems at both sites. These differences will be monitored in subsequent years to provide insight into the effects of different soil sources of these elements.

\section{FUTURE RESEARCH}

An emerging large-scale view of the earth and its processes is resulting in dramatic new insights regarding the causes and repercussions of environmental changes. Our ability to capitalize on these insights will depend on our success in designing and applying state-of-the-art data acquisition and data management systems to environmental data sets.

The aerial, satellite, and ground-based data acquisition systems that exist today are providing the information needed to address critical questions concerning interactions within an environmental system that result in environmental changes. However, we must simultaneously account for the natural temporal and spatial variability that is inherent within an environmental system. Such variabilities are critical when identifying or interpreting developing trends. Statistical models that now exist are not adequate to meet this need. Some specific areas for future research emphasis include the following:

- development of an ability to measure the aggradation and degradation of natural systems over large areas (i.e., region, continent or global)

- identification of critical processes governing the response and recovery of ecosystems to natural and human-related stresses

- development of techniques to discern natural variability from anthropogenic causes

- development of the capability to integrate large data sets quickly and efficiently for managing both local and large-scale land use patterns.

The research areas outlined above will be possible only if long-term studies focused on understanding environmental processes can continue within protected study areas. The Hanford NERP currently provides this protection. It is critical that this protection continue if we are to achieve the goal of understanding landscape level changes within the environment. 
Site-to-Site Comparison
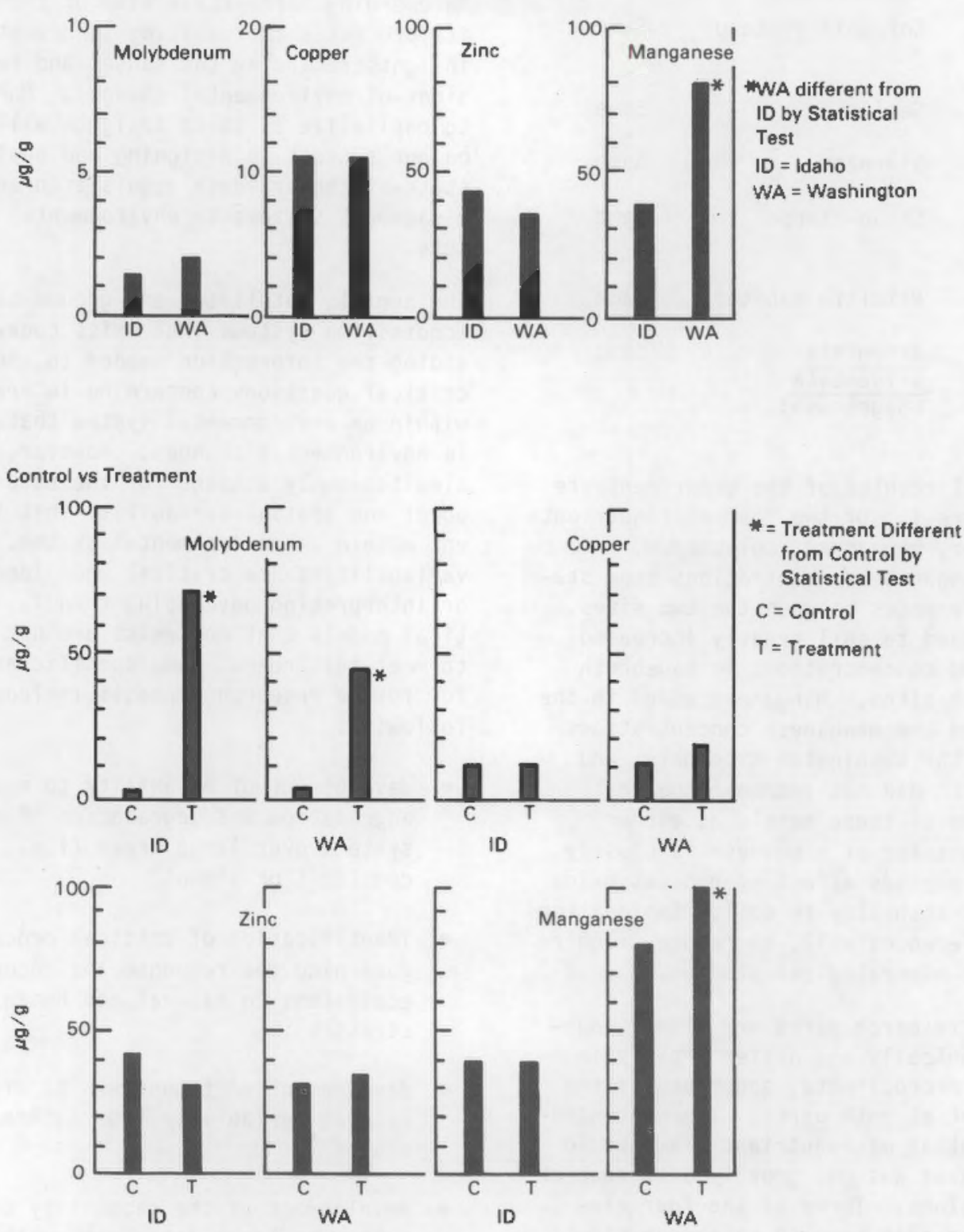

FIGURE 1. Concentrations of Trace Metals in Sagebrush Leaves in Idaho and Washington and the Response of Leaves to Trace Metals Added to Surface Soil Beneath the Shrubs. 


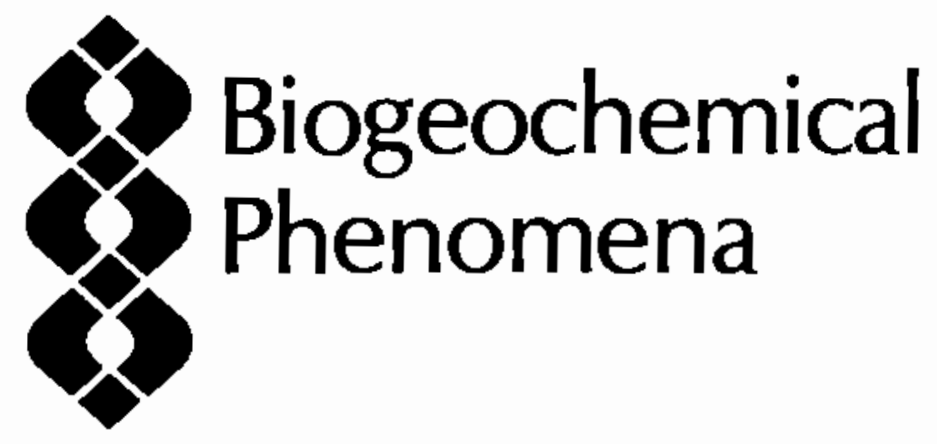




\section{- Biogeochemical Phenomena}

Complex relationships between chemical and biological phenomena markedly affect the cycling, transfer, and form of inorganic and organic constituents in terrestrial and atmospheric systems. These processes often have global as well as human health implications. PNL has pioneered research on metabolic processes that influence the transfer of radionuclides, energy-related metals, and organic compounds in microbial soil-plant-animal systems. These investigations have provided a unique background for probing fundamental biological controls on elemental cycling in these systems.

This program is directed toward development of an understanding of biogeochemical phenomena controlling the behavior of representative classes of inorganic elements and organic compounds important in global cycling and pathways. In addition, basic concepts developed in the laboratory are being validated in controlled field studies. The information is being used to add kinetic and metabolic dimensions to elemental cycling and food ingestion models, which previously lacked long-term predictive capability and the ability to incorporate metabolic products of organic chemicals.

SOIL AND PLANT PROCESSES CONTROLLING CATION BEHAVIOR IN TERRESTRIAL SYSTEMS

R. E. Wildung, D. A. Cataldo, and J. K. Fredrickson

The environmental mobility and kinetics of inorganic pollutant solubilization, particularly for cations, are regulated directly and indirectly by specific biological processes. These processes, which are related to soil microbial, rhizosphere, and plant metabolic functions, alter the thermodynamic equilibria controlling cation speciation and complexation, and therefore alter cation behavior. Thus, an understanding of these biotic processes is essential in predicting the spatial and temporal mobility of elements after the terrestrial ecosystem is stressed physically or chemically. An integrated field and laboratory approach is used to define, assess, and quantify those processes which influence metal speciation in the nearsurface environment.

In 1986, research addressed 1) the role of soil microorganisms as a source of ligands for metal complexation; 2) the mechanisms employed in higher plants to maintain the solubility of cations prone to hydrolysis, including both nutrient and non-nutrient ions; 3) the initiation of rhizosphere studies to define the chemical environment in the near-surface root zone; and 4) an assessment of using the Chernobyl event to establish thermodynamic and kinetic parameters for cation (cesium) interactions with clay minerals and the resulting effects on cation concentration in soil solutions and availability to plants.
Previous investigations tested the original hypothesis of the role of metabolism in influencing cation behavior by identifying soil microbial and plant ligands important in the transport and immobilization of metals. Plants were shown to utilize low molecular weight organic acids, amino acids, and peptides as major metal-complexing ligands. Amino and organic acids are also known to be major components of carbonaceous root secretions. It was hypothesized that rhizosphere microorganisms metabolize these compounds, forming a number of secondary metabolites that also serve as metal-complexing agents. In 1986, efforts were concentrated on characterizing rhizosphere microbial metabolites and root exudates involved in cation complexation.

Three native grasses, bluebunch wheatgrass, thickspike wheatgrass, and sandburg bluegrass, were seeded into Ritzville soil amended with ${ }^{63} \mathrm{Ni}$ as a tracer. Growth containers were designed in such a way that plant roots could intensively exploit the soil and the entire volume could be considered rhizosphere soil. Rhizosphere solutions were collected by centrifugation/filtration and characterized by thin-layer chromatography and thin-layer electrophoresis in conjunction with autoradiography. Nickelcomplexing ligand chromatography patterns were then compared for the three native grass rhizospheres and nonrhizosphere soil.

The distribution of ${ }^{63} \mathrm{Ni}$ in the plant-soil continuum, after the grasses reached maximum rooting density, indicated that trace amounts were present in the leaves, between $0.8 \%$ and 1.7\% was present in root tissue or adsorbed 
on root surfaces, between $0.04 \%$ and $0.09 \%$ was present in soluble forms in the rhizosphere, and the rest remained in soil nonsoluble forms. While similar quantities of ${ }^{63} \mathrm{Ni}$ were present as soluble complexes in the rhizosphere and soil solutions (Figure 1), their chromatographic patterns were quite distinct, indicating that different organic components were responsible for complexation. In addition, fractions complexing ${ }^{63} \mathrm{Ni}$ in the soil alone were absent in the soil rhizosphere solutions, suggesting that the complexes were quite different and that rhizosphere ligands have a greater affinity for cations than do ligands present in the nonrhizosphere soil solutions. Chromatographs for ${ }^{63} \mathrm{Ni}$ complexes were similar for the three native grasses, suggesting a commonality in root exudation patterns and rhizosphere microbial metabolites. Thus, an examination of these complexes should provide general insight into the grass rhizosphere system.

Efforts to further characterize these rhizosphere ligands are continuing, using an artificial plant growth medium in order to more clearly delineate soil organic complexes from those produced exclusively in the rhizosphere. In addition, experiments will be expanded to include characterization of trace element ligands produced during plant litter decomposition.

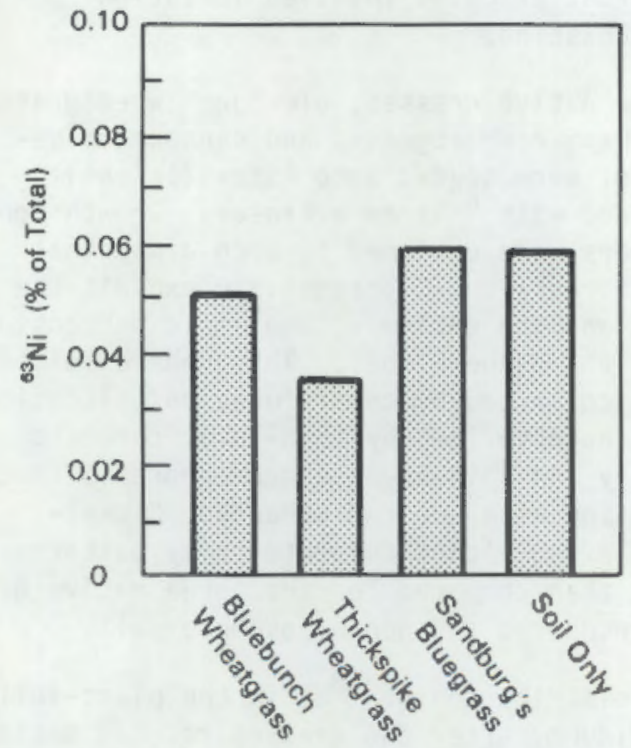

FIGURE 1. Fraction of ${ }^{63} \mathrm{Ni}$ Added to Ritzville Soil and Present as Soluble Complexes in Rhizosphere and Nonrhizosphere Solutions
The role of terrestrial plants in accumulating and modifying the chemical form of cations represents an important aspect of contaminant flow and chemical fate because of the comparatively large biomass contribution of plants and their key position in the food web. Thus, in addition to investigating rhizosphere secretions, research has been directed toward 1) elucidation of the metabolic factors regulating cation absorption by roots and transfer from root to shoot, 2) elucidation of complexation mechanisms for stabilizing cations in xylem transport fluids, 3) analys is of cation forms stored in roots and leaves, and 4 ) analys is of the impact of litter decomposition processes on the seasonal flux and mobility of cations in soils and plants.

Research on plant metabolic processes has been directed toward understanding those endogenous plant processes influencing the quality and quantity of metal complexes in plants. Specifically, this effort involved examining the production of noninduced and metal-induced complexing ligands and elucidating the mechanics of metal complexation by evaluating mode1 plant transport ( $x y$ lem exudate) systems with respect to ligand specificity for essential nutrient ions and pollutant elements.

Results to date indicate that 1) at least two complexation mechanisms dominate for the elements investigated, one for divalent cations and one for polyvalent cations; 2) the mechanism for divalent ions appears to involve small peptides with a specificity for a range of ions; and 3) the concentration of these peptides is increased by the presence of cadmium, cobalt, and nickel.

Detailed analyses of xylem exudates from soybean plants demonstrate that $\mathrm{Fe}^{+3}, \mathrm{Pu}^{+4}$, and $\mathrm{Np}^{+4}$ are complexed and chemically stabilized by simple organic acids while in transport from root to shoot. This mechanism may also be functional for a range of polyvalent cations (including chromium), other trans uranic elements, and the rare earths. The second complexation mechanism employs small peptides having high stability constants and specificity for the divalent cations $\mathrm{Ni}, \mathrm{Cu}$, and $\mathrm{Zn}$. While several peptides have been isolated from squash, snap pea, bushbean, and soybean plants, efforts have concentrated on the peptide responsible for $\mathrm{Ni}$ complexation 
in soybean. Figure 2 shows the peptides found in soybean xylem exudates. Component 92 is a peptide containing aspartate, gluamate, and an unknown 440-nm absorbing acid, with a mole ratio of $3: 1: x$. This peptide is endogenous to xylem exudates, and can bind or complex up to $14 \mu \mathrm{M}$ of either $\mathrm{Ni}, \mathrm{Cu}$, or $Z n$. The affinity of this ligand is $\mathrm{Ni}>\mathrm{Zn}>\mathrm{Cu}$, with $\mathrm{Ni}$ readily displacing $\mathrm{Zn}$ and $\mathrm{Cu}$ on metal amendment of xylem exudates. Preliminary results indicate that some commonality existed in the types of peptides present in soybean, squash, snap pea, and bushbean exudates, thereby suggesting that similar complexation mechanisms for transport fluids may occur.

Investigations of the effects of chronic metal exposure on the transfer of metals from soybean root to shogt were performed for $\mathrm{Ni}^{+2}, \mathrm{Cd}^{+2}$, and $\mathrm{Co}^{+2}$. Approximately 6 days of pre-exposure were required before increased metal concentrations were observed in xylem exudates. Induction causes a fivefold increase in metal transfer from root to shoot for nickel and cadmium, and a tenfold

XE-2, FRA

Nonhydrolyzed

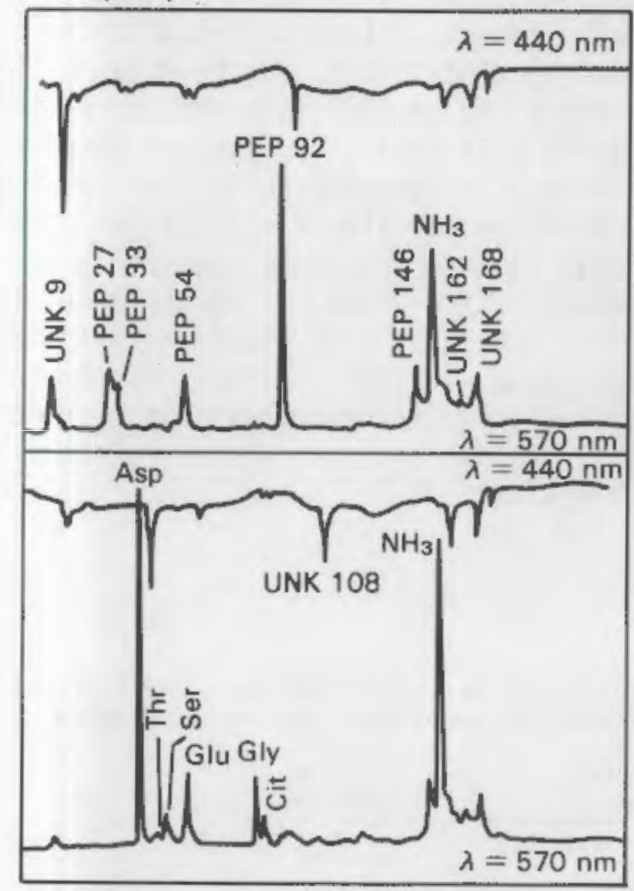

XE-2, FRA

Hydrolyzed

FIGURE 2. Chromatogram Showing the Peptides Derived from Xylem Exudates Containing $16 \mu \mathrm{M} \mathrm{Ni}$. increase for Co. Analysis of individual peptides for control and induced plants showed that the principal transport peptide increased in concentration in response to $\mathrm{Ni}$, whereas other peptides increased in response to $\mathrm{Cd}$ induction.

Microbial and plant systems clearly demonstrate the importance of biological processes on metal form and biological transport. The fact that stable organo-metal complexes are readily formed can eventually influence their mobility and soil transport, once these complexes enter the soil via normal processes that occur within the rhizosphere, or during dieback and decomposition of tissues.

\section{ENVIRONMENTAL BEHAVIOR OF INORGANIC ANIONS}

T. R. Garland, D. A. Cataldo, R. J. Fellows, R. E. Wildung

Recent efforts have addressed two aspects of anion behavior in the soil/plant system. The first involves evaluation of the gaseous component of the terrestrial iodine cycle in soils and plants, while the second is concerned with the metabolic fate and behavior of technetium in plants.

\section{Iodine Cycling}

It has long been known that inorganic radioiodine/radioiodide released from nuclear reactors and fuel reprocessing operations and amended to soils is readily released to the atmosphere in volatile form. Furthermore, field analyses of ${ }^{129}$ I in soils and vegetation adjacent to a fuels reprocessing facility, which was idle for 10 years prior to the study, indicated that there may be a significant gaseous component to the terrestrial iodine cycle. Soil substrates, including a silt-sand, organic forest soil, quartz sand, and a sterilized soil, were amended with radioiodide, and the rates and quality of the volatile components evaluated.

The results indicate that rates of volatilization are approximately $1 \times 10^{-4} \%$ per day at environnental concentrations, release rates are proportional to amended concentration, and while volatile forms are organic in nature they do not appear to be of biological origin. Soils containing plant roots exhibit an increased rate of iodine volatilization, 
$2 \times 10^{-3} \%$ per day, with approximately $30 \%$ of the iodine in an inorganic form. The volatile iodine species released from soil are readily adsorbed to and/or absorbed by plant foliage. Radioiodide absorbed from soils and transported to foliage was also observed to be released in volatile form to the atmosphere. Rates of release average $1 \times 10^{-2} \%$ per day, and consist of $25 \%$ inorganic species and $75 \%$ organic forms. These studies clearly demonstrate that a terrestrial iodine cycle exists. Currently, studies are underway to identify the major volatile organic and inorganic species produced in soils and by plant foliage.

\section{Chemical Fate of Technetium in Plants}

Technetium is believed to readily exist as its oxyanion, pertechnetate, in aerobic systems. As such, it is soil mobile, bioavailable, and thus is peculiar compared to other major contaminants derived from the nuclear fuel cycle. However, evidence exists indicating that $T_{C}$ is insolubilized in soil under certain conditions, and based on animal ingestion studies with the oxyanion form and plant-incorporated Tc forms, Tc is reduced on uptake by plants. Dur ongoing efforts strongly suggest that $T C$ is biologically reduced and chemically incorporated into proteins, using enzyme systems in place for sulfur metabolism.

The evidence for metabolically mediated Tc incorporation include 1) its relatively high chemical toxicity, especially in meristems where synthesis of new protein is essential to tissue survival; 2) the rapid increase in nitrate reductase activity, and increased protein production in the presence of Tc; and 3 ) the association of $T c$ with a wide range of proteins below 20,000 molecular weight, but not the larger proteins, suggesting an inability to form the quartenary structure requiring disulfide linkages. Based on these data, it has been proposed that $T c$ is substituting for sulfur, undergoing enzymatic reduction and incorporation, and thus represents a nonfunctional analog of sulfur.

Time course studies of the chemical fate of technetium, sulfur, and selenium ions in leaves and roots show that the incorporation of all three ions occurs principally within the leaves. Analysis of accumulation patterns in leaves show soluble pertechnetate pools to be low, and chloroplasts to be a major site of accumulation for insoluble Tc. This behavior is consistent with enzymatic reduction of $T_{C}$ and $S$, which is chloroplast based. Since it is well established that the enzyme system responsible for the reduction and incorporation of $S$ and $S e$ into their amino acid analogs are found only in the chloroplast, in vitro incorporation studies were performed with isolated chloroplasts. Results for $S, S e$, and $T c$ are shown in Table 1. In each case, the reaction mixture yielded a cationic component following electrophoresis. These were found to co-chromatograph on ion exchange with cysteine and seleno-cysteine standards. The incorporated $T C$, while as yet not authenticated, did yield a ninhydrin-positive component with a retention time of $155 \mathrm{~min}$. Based on these preliminary results, it appears that. $T_{c}$ is reduced by glutathione reductase, as is the case for $\mathrm{S}$ and $\mathrm{Se}$, and is incorporated into its amino acid analog by cysteine synthase. It should be noted that while the reduction step normally results in a 2- state for $S$ and Se, this valence state has never been observed for $T c$. Thus, if reduction of $T c$ involves the 1-valence, then the amino acid formed would lack the ability to form the classical bridging characteristic of functional complex proteins, which would explain its toxicity.

TABLE 1. Plant Metabolic Mechanisms for Reduction and Incorporation of the Oxyanions of Sulfur and Selenium, and Possible Substitution by Technetium in Enzymatic Pathways Employing Glutathione (GHS) Reductase and Cysteine Synthase.

\begin{tabular}{|c|c|c|c|c|}
\hline $\begin{array}{c}\text { Plant Available } \\
\text { Oxyanion (Valence) }\end{array}$ & $\begin{array}{c}\text { GSH } \\
\text { Reductase }\end{array}$ & $\begin{array}{l}\text { Reduced } \\
\text { Form }\end{array}$ & $\begin{array}{l}\text { Cysteine } \\
\text { Synthase }\end{array}$ & $\begin{array}{l}\text { End } \\
\text { Product }\end{array}$ \\
\hline $\mathrm{SO}_{4}{ }^{2-} / \mathrm{SO}_{3}{ }^{2-}(+6 /+4)$ & $--->$ & $\mathrm{s}^{2-}$ & $--->$ & cysteine \\
\hline $\mathrm{SeO}_{3}^{2-}(+4)$ & $--->$ & $\mathrm{Se}^{2-}$ & $--->$ & $\begin{array}{l}\text { seleno- } \\
\text { cysteine }\end{array}$ \\
\hline $\mathrm{TcO}_{4}{ }^{1}-(+7)$ & $--->$ & $\mathrm{Tc}^{2-/ 1-}$ & $--->$ & Tc-cysteine \\
\hline
\end{tabular}


SOIL/PLANT BEHAVIOR OF ORGANIC XENOBIOTICS

\section{A. Cataldo, R, J. Fellows, R. M. Rean}

Organic pollutants released to the environment as a result of man's activities can result in a range of perceived and/or real environmental and health concerns. However, the myriad of individual compounds of potential interest presents a very real problem in inderstanding the general fate and impacts of organic residues entering the environment. In the past, the selection of compounds for study was based on either their perceived importance, as in the case of PAHs, or because they were present in emissions from specific sources. The large number and types of organic residues entering the environment make this approach less than suitable for predictive purposes. The preferred approach is a systematic evaluation of the comparative behavior of a range of representative organic pollutants. These should include important compound classes varying in physicochemical properties, and within each class, a series of representative compounds with increasing complexity and substitution. This framework provides a systematic data base from which the behavior of a wide range of organic residues can be assessed.

In the present studies, the comparative behavior and chemical fate of organic residues in plants are evaluated in simple soil and hydroponic systems. Organic compounds were selected from the 28 representative species comprising seven compound classes currently being evaluated in DOE/OHER subsurface transport programs. The objectives of these studies are to establish 1) root absorption rates for individual organic residues, 2) plant mobility and distribution patterns, 3) rates of foliar volatilization and reemission to the atmosphere, and 4) the chemical fate of these compounds once accumulated. Four compounds, representing four of the compound classes, have heen studied: phenol, aniline, quinoline, and most recently indole. The wide range in relative behavior and chemical fate observed with these compounds serves to demonstrate the complexities involved in understanding the environmental behavior of xenobiotics.

Experiments using indole labeled with ${ }^{14} \mathrm{C}$ in both soils and hydroponic systems demonstrated that soybeans were able to accumulate significant amounts of label within short periods of time. Twenty-one-day-old plants grown in a $50-\mathrm{ppm} 14 \mathrm{c}$-indole hydroponic solution accumulated over $37 \%$ of the total sup. plied label within $72 \mathrm{hr}$; plants grown from seed in soil amended with 50-ppm $14 c$-injole accumulated over $20 \%$ of the total supplied label after 30 days.

However, when the plants were analyzed for the parent compound indole, little or no material was observed within the roots $(<0.1 \%$ to $0.5 \%$ of initial concentration), and no material was detected in either the stens or leaves. A more detailed analysis of those compounds that contained label derived from indole was therefore conducted. The results of a typical analysis are given in Table 1.

Roots contained approximately $70 \%$ of the total label accumulated by the plants. within the roots, the ${ }^{14} \mathrm{C}$ was predominantly found in the protein and insoluble (cell wall and structural protein) fractions, while the basic (amino acid) fraction of the water/ alcohol extract (solubles) contained a majority of the ${ }^{14} \mathrm{C}$. Amino acid andysis of the basic fraction further revealed that more than $90 \%$ of the label associated with this fraction was recovered in tryptophan.

In stem tissue, approximately half of the ${ }^{14} \mathrm{C}$ was found to be in the insoluble fraction, while $36 \%$ was recovered in the water/alcohol soluble fraction. Following ion exchange separation of the soluble fraction, $90 \%$ of the label was found to be in the amino acids, and again, more than $80 \%$ of the label was recovered in tryptophan. Once accumulated in leaves, the ${ }^{14} \mathrm{C}$ partitioned mainty into the protein and the water/alcohol soluble fractions. The amino acids contained over half of the ${ }^{14} \mathrm{C}$ in the water/alcohol fraction, with greater than $70 \%$ of the amino acids being tryptophan. Acid hydrolysis of protein fractions indicate that the associated $14 \mathrm{C}$ is in tryptophan.

Although indole is an intermediate metabolite in synthetic pathways for several compounds, including the auxins and the amino acid tryptophan, indole does not accumulate in

tissues. Experinental rasults indicate that indole, once absorbed by roots $(96.1 \mathrm{ug}$ indole/g dry wt/hr), is rapidly assimilated and metabolized by the roots of soybeans. This occurs by the tryptophan synthesis 
IABLE 1. Distribution of ${ }^{14} \mathrm{C}$ Derived from Indole Within 21-Day-Old Soybean (Clycine max cv. Williams) Plants Following 72-hr Incubation in a 50-ppm Indole-Hydroponic Solution.

\begin{tabular}{|c|c|c|c|}
\hline Sample/Fraction & Root & $\begin{array}{c}\text { \% Total }{ }^{14} \mathrm{C} \text { Recovered } \\
\text { Plant Segment } \\
\text { Stem } \\
\end{array}$ & Leaves \\
\hline Total Plant & 70.72 & 13.35 & 15.93 \\
\hline $\begin{array}{l}\text { Solubles } \\
\text { Water/Alcohol } \\
\text { Chloroform } \\
\text { Pratein } \\
\text { Starch } \\
\text { Insoluble }\end{array}$ & $\begin{array}{r}13.73 \\
7.14 \\
35.65 \\
5.07 \\
38.42\end{array}$ & $\begin{array}{r}35.58 \\
2.40 \\
4.68 \\
6.31 \\
51.03\end{array}$ & $\begin{array}{r}20.47 \\
2.46 \\
56.20 \\
10.38 \\
10.49\end{array}$ \\
\hline & 100.0 & 100.0 & 100.0 \\
\hline $\begin{array}{l}\text { Water/Alcohol-Ion Exchange } \\
\text { Neutral(a) of soluble fractions } \\
\text { Basic(b) } \\
\text { Acid I(c) } \\
\text { Acid II(d) }\end{array}$ & $\begin{array}{r}14.94 \\
61.91 \\
17.73 \\
5.42 \\
\end{array}$ & $\begin{array}{r}4.25 \\
88.97 \\
4.50 \\
2.28 \\
\end{array}$ & $\begin{array}{r}19.71 \\
62.41 \\
14.99 \\
2.89 \\
\end{array}$ \\
\hline & 100.0 & 100.0 & 100.0 \\
\hline $\begin{array}{l}\text { (a) Sugars } \\
\text { (b) Amino acids } \\
\text { (c) Organic acids } \\
\text { (d) Sugar phosphates }\end{array}$ & & & \\
\hline
\end{tabular}

pathway, with a significant fraction being incorporated into soluble and structural proteins. In addition, excess tryptophan appears to be the major, if not sole, transport form moving from root to shoot. This is supported by the fact that no indole could be isolated or identified in stem or leaf tissues.

Indole, like phenol, appears to be rapidly metabolized by the plant and converted to natural components. However, unlike phenol, aniline, or quinoline, the primary site of indole accumulation within the plant may be in proteins or amino acid-derived compounds.

\section{FUTURE RESFARCH}

The primary goal of this research is to define the influence of soil microbial and plant processes on the behavior of specific representive inorganic elements and organic compounds. The fundamental metabolic approach taken to achieve this goal is now providing the basis for evaluating the concepts developed for describing more general phenomena and defining the soil micrabialplant root environment as an integrated system.

Research to define the role of plant ligands in the transport of polyvalent cations will build on previous results that indicated the importance of both specific peptides as complexing ligands in the plant xylem, and several distinct low molecular weight complexing ligands in the plant rhizosphere.

Concurrently, a specialized model system to examine rhizosphere ligands in the absence of soil will be employed to define rhizosphere leachates from native and agronomic plant species important to the shrub-steppe regions of the world.

Research to define the behavior of anions in soil is currently centered on 1) examination of metabolic processes responsible for technetium reduction and incorporation;

2) initiation of detailed studies to quantitate the gaseous fluxes of nitrogen, sulfur, selenium, iodine, and trace oxyanions from oil and plant rhizospheres; and 
3) initiation of studies on the effects of oxyanions (initially technetium) on soil nitrogen cycling and the relationship to oxyanion mobility in soit.

Field investigations will be focused on establishing a basis for refining and calibrating thermodynamic equilibrium and netabolic transport models for both cation and anion elements.

Thus, the biogeochemical studies have evolved to the point where major contributions to our general understanding of key processes controlling elemental cycling can now be realized. 

Subsurface Transport 


\section{- Subsurface Transport}

Research on the transport and fate of contaminants in the subsurface environment focuses on microbiological, chemical, and hydrologic phenomena controlling the movement and persistence of organic chemicals in the vadose and saturated zones. The intent of the PNL program is to improve numerical predictions of contaminant transport by advancing the scientific understanding of governing phenomena. The research is fundamental, and targets the subsurface behavior of complex organic solute mixtures and miscible and immiscible organic liquids. Microbiological research focuses on the nature of organisms in the deep subsurface (a newly realized, unexplored ecosystem) and their ability to degrade organic contaminants under diverse hydrochemical conditions. Subsurface chemistry studies are probing sorption and other interfacial chemical reactions limiting solute movement. Hydrologic investigations are defining the physics and fluid dynamics of organic liquid/water multiphase mixtures in porous media. Hypothesisdriven experiments are first carried out in the laboratory with selective field sampling to resolve intradisciplinary issues. Subsequently, multidisciplinary experiments are performed at the intermediate scale and in the laboratory to control and carefully manipulate hydrologic and other critical parameters.

\section{SUBSURFACE CHEMISTRY OF ORGANIC COMPOUNDS}

J. M. Zachara and C. C. Ainsworth

Experimental investigations of multispecies solute interactions with subsoil and aquifer materials are being performed and described with chemical equilibrium models to improve predictions of contaminant migration in subsurface environments. Carefully selected organic compounds are used in combination with both mineral/hydrocarbonaceous surfaces varying in charge and hydrophobicity and subsurface materials of diverse properties to probe sorption and surface-catalyzed reactions. In keeping with these objectives, research over the past year has focused on 1) the limits of carbon-referenced sorption on subsurface materials, using a neutral, nitrogen-containing, aromatic compound; 2) the influence of dissolved cosolvent on the sorption of ionizable and neutral $\mathrm{N}$-containing aromatic compounds by subsurface materials and clays; and 3 ) the sorption and surface complexation of $\mathrm{N}$-containing aromatic compounds by amorphous silica. These studies have advanced our understanding of the relative contributions of electrostatic versus hydrophobic interactions and the importance of steric effects in the sorption process.

To investigate the limits of carbon-reference sorption, experiments were performed with a polar $\mathrm{N}$-heterocyclic compound (carbazole, pKa $a-2$ ) on 21 soil and subsurface materials exhibiting a wide range of properties. Carbazole sorption was shown to be highly correlated with the organic carbon content $(O C)$ as shown for other hydrophobic compounds (HOCs). Unlike HOCs, nonlinear carbazole adsorption was observed, yielding a Freundich isotherm described by the exponential term $(N)<1$. Linearizing the isotherms yielded a $K_{o c}$ [sorption constant $\left(K_{f}\right)$ normalized for $0 C]$, which was greater by a factor of 7 than that calculated from the octanol-water partition coefficient $\left(K_{\text {ow }}\right)$. The $K_{o c}$ determined from the nonlinear isotherm constants (normalized to an average value) was close to that calculated from the Kow'

The nonlinear adsorption isotherms were segregated in two distinct groups differing in their Freundlich experimental terms; one group had $N$ values ranging from 0.87 to 0.81 , and the second group ranged from 0.75 to 0.66 . The latter group was dominated by subsoils high in oxides and calcite, while the nonoxidic group contained 2:1 lattice silicates. In both groups, carbazole sorption was highly correlated with $0 C$. Significantly, however, the $K_{o c} c a l c u l a t e d$ for the oxidic group was consistently less than the $K_{\text {oC }}$ calculated from the $K_{o w}$ for carbazole.

Limited data suggest that carbon-referenced sorption deteriorates in subsurface materials when the ratio of percent $O C /$ percent $c l a y$ falls below approximately 0.01 . For hydrophobic compounds, the isotherm-determined $\mathrm{K}_{\mathrm{OC}}$ below a threshold value typically increases to well above that calculated from the $\mathrm{K}_{\text {ow }}$. In contrast, the $K_{O C}$ values determined for carbazole decreased dramatically as the OC/ clay ratio dropped below 0.02 (Figure 1 ). Importantly, the majority of subsurface materials that showed this decrease were from the axidic group. In fact, even when the $0 c / c$ lay ratio was considerably higher than 0.02 , the 


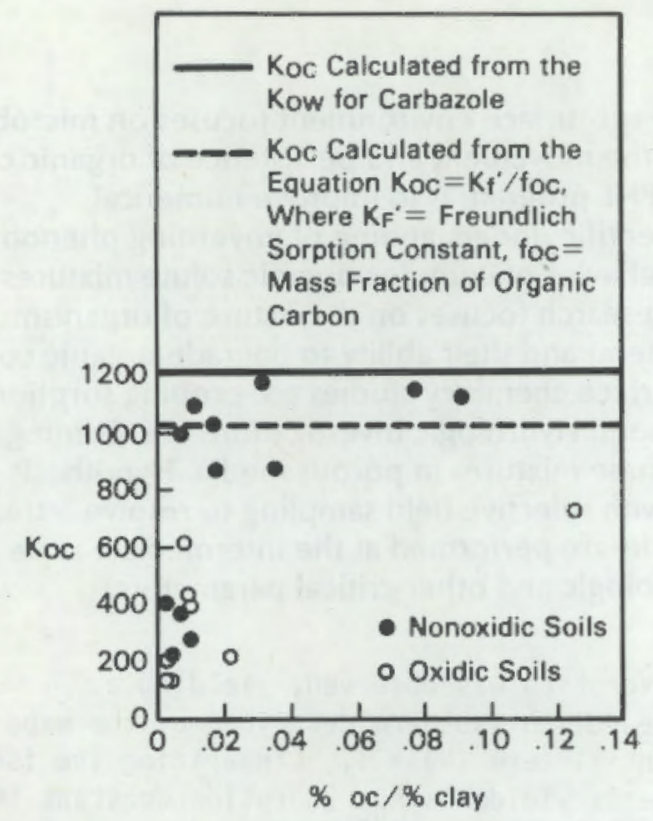

FIGURE 1. The Importance of Organic Carbon as a Sorbent for Carbazole Decreases as the Percent Organic Carbon to Percent Clay Ratio Falls 8elow 0.02 . Organic coatings on mineral surfaces may be a less effective sorbent than particulate organic material.

isotherm $K_{o c}$ values for the oxidic group were considerably less than that of the other group. These results indicate that while partitioning to the $\mathrm{OC}$ phase of soil is probably the driving force in carbazole sorption, sorption is also influenced by subtle properties of the organic carbon fraction that differ between soil groups and geographic environs.

The limit of carbon-referenced sorption was also investigated for carbazole sorption on soils from water-methanol, water-acetone, and water-pyridine mixtures. The selection of the cosolvents was based on their prevalence in waste environments and their physical properties. Carbazole sorption, like that seen with HOCs, is decreased with the addition of cosolvents methanol and acetone (with the latter inducing the greater decrease). The decrease in sorption caused by these two cosolvents is log-linear with an increasing mole fraction. Additionally, there was no apparent difference in the slopes of the loglinear relationships between subsurface materials for acetone, and only very slight differences in the slopes with methanol as the cosolvent. The cosolvent effect for nonionizable solutes may be ascribed to enchanced solvation, which reduces the entropic forces driving sorption.

Carbazole sorption in the presence of the cosolvent pyridine was increased in one soil and only slightly affected in another. Pyridine is ionizable ( $p K a=5.25$ ) and will adsorb to the soil, rendering charged surfaces more hydrophobic. Pyridine will also increase the solubility of carbazole in the bulk solvent phase and decrease the solvophobic forces driving sorption. The presence of pyridine may, therefore, drive sorption of carbazole in opposite directions, depending upon the pyridine concentration in the solvent and the $\mathrm{pH}$ of the subsurface material. Our experiments show that pyridine may induce a wide range in sorption behavior, from enhanced to depressed.

Sorption experiments were also performed with an ionogenic organic compound (quinoline, pKa $=4.93$ ) on subsoils from water-methanol and water-acetone mixtures to identify the magnitude and mechanism of cosolvent effects where compound ionization is significant. As observed for HOCs, cosolvent addition decreases sorption, with acetone inducing the greatest depression. This depression parallels the low dielectric constant of acetone and the high solubility of quinoline in acetone as compared to both methanol and water. More specifically, a log-linear decrease in the sorption coefficient is noted with an increasing mole fraction of solvent. Unlike

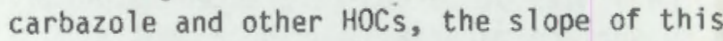
log-linear relationship varies between the different subsoils, reflecting their $\mathrm{pH}$ and the extent of compound ionization.

To probe this apparent "pH-dependent" cosolvent effect, quinoline sorption was measured on a subsurface material, its clay fraction, and montmorillonite in the presence of acetone and methanol over a wide range in $\mathrm{pH}$. In aqueous electrolyte $\left(0.01 \mathrm{M} \mathrm{NaClO}_{4}\right)$, quinoline sorption on all three sorhents was demonstrated to be identical when they were adjusted to equal concentrations on a charge basis, demonstrating the nonspecific electrostatic nature of the sorption process. The presence of a cosolvent reduced the surface affinity of quinoline over the entire $\mathrm{pH}$ range on all three adsorbents. In a cosolvent mixture, sorption still paralleled the ionization fraction as shown in Figure 2 for a subsurface material, indicating continued 

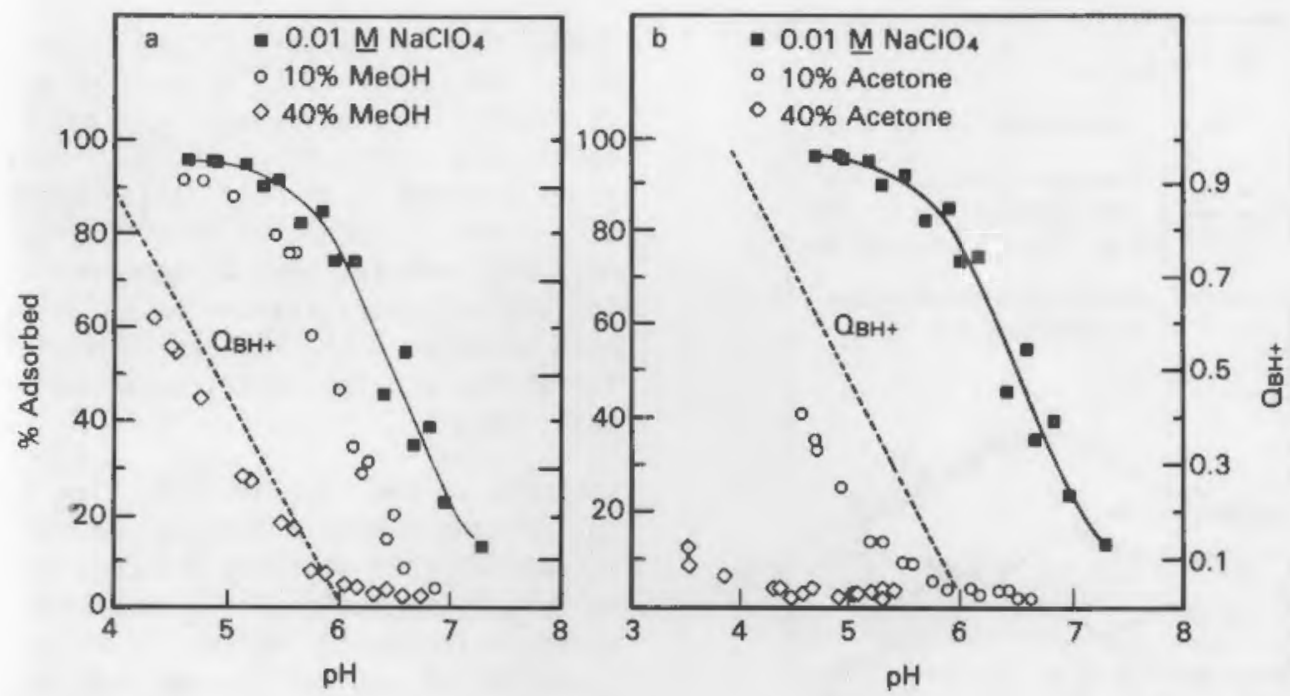

FIGURES 2a and 2b. Miscible Cosolvents (Methanol-Figure 2a and Acetone-Figure 2b) Reduce Quinoline Sorption to Subsurface Materials by Altering the Solvation of the Organic Cation and $\mathrm{Na}^{+}$Competing for Surface Sites.

predominance of ion exchange. These results are consistent with a solute-solvent model where solvation of the organic cation increases and solvation of the inorganic cation decreases in the presence of a cosolvent. The net effect is to reduce hydrophobic stabilization of the organic cation surface complex and enhance desolvation of $\mathrm{Na}^{+}$at the charged surface. These both drive the exchange reaction

$$
\mathrm{NaX}+\mathrm{BH}^{+} \neq \mathrm{BHX}+\mathrm{Na}^{+}
$$

to the left.

Silica $\left(\mathrm{SiO}_{2}\right)$ represents an important protonspecific colloidal surface in the subsurface. It may exist as a mobile colloidal particle or as a coating on stationary solids. The surface of silica is weak acid that ionizes with increasing $\mathrm{pH}$, providing negatively charged surface sites. The sorption of aminonaphthalene and quinoline has been investigated on porous and nonporous $\mathrm{SiO}_{2}$ microparticles as a function of major solution variables $(\mathrm{pH}$, ionic strength, electrolyte ion charge, and temperature) to assess the importance of charge location, pKa, hydrophobic bonding, and steric effects on organic surface complexation. These two-ring $\mathrm{N}$-containing aromatic compounds exhibit dif ferent pKas and solubility as a result of nitrogen placement in the ring. Both ionize to organic cations below their pka.

Both solutes are sorbed by amorphous $\mathrm{SiO}_{2}$, with quinoline exhibiting higher preference for the surface. In direct contrast to layer silicates, where compound ionization controls binding, sorption on $\mathrm{SiO}_{2}(\mathrm{am})$ is mildly $\mathrm{pH}-$ dependent, with maximum sorption noted near the pKa. Enhanced sorption of quinoline over naphthylamine is apparently a steric effect, whereby the charged moiety or stabilizing ring system on the $\mathrm{N}$-heterocycle may approach the surface of $\mathrm{SiO}_{2}$ more closely. The changes in sorption that accompany variations in ionic strength, valence of the electrolyte $i$ ons, and temperature indicate that reactions between both charged and neutral species are responsible for the overall sorption process. A site-binding model, incorporating surface and solution ionization reactions, has been used to simulate the adsorption behavior. The $\mathrm{pH}$-dependent adsorption (Figure 3 ) is well described with three surface reactions on both charged and neutral sites. 


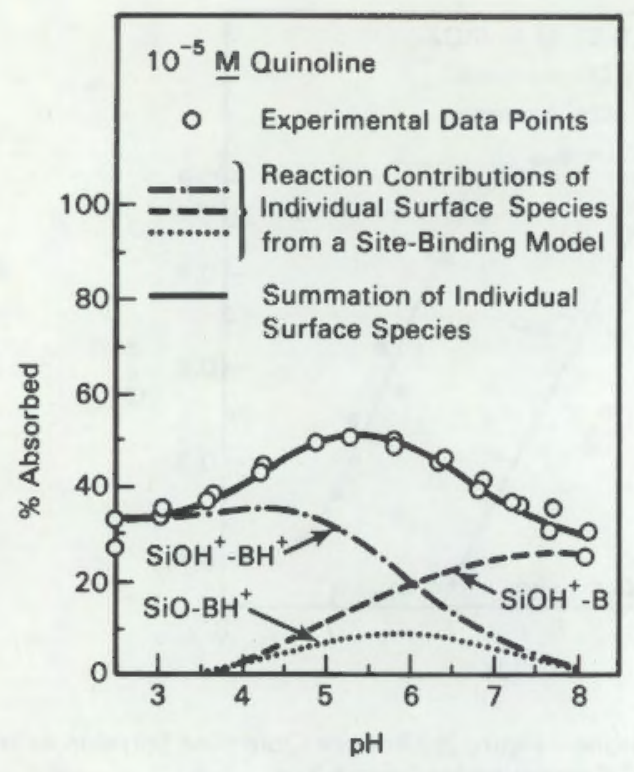

FIGURE 3. Quinoline Sorption on Amorphous Silica Can Be Simulated Using Three Surface Reactions in a SiteBinding Double-Layer Model.

\section{SUBSURFACE MICROBIAL PHENOMENA}

\section{J. K. Fredrickson and R. J. Hicks}

Biological reactions have a major influence on organic contaminant persistence and transport in subsurface environments. In spite of this, knowledge of the identity and functions of microorganisms in the subsurface lags far behind that of the related fields of aquifer fluid dynamics and interfacial chemistry. Therefore, fundamental investigations are being conducted at PNL to probe the microbial diversity and physiological processes governing the fate of aromatic organic compounds in the subsurface. Research is focused on the microbial degradation of $\mathrm{N}$-containing aromatic compounds as influenced by key physicochemical parameters, such as the solubility, concentration, and dipole moment of the organic contaminant; competing organic substrates; sorption reactions; and the oxidative state of the environment. Results of this research are expected to provide an improved understanding of the role of microorganisms in transformation and transport of organic contaminants in the subsurface.

Experimental studies in FY96 focused on characterizing the diversity and activities of microorganisms in deep subsurface cores (to a depth of $300 \mathrm{~m}$ ) obtained from the Savannah River Laboratory (SRL) as part of a cooperative effort between university and national laboratory scientists. At PNL, investigations focused on 1) examination of the aerobic metabolic capabilities of indigenous microbial populations; 2) enumeration, isolation, and characterization of aerobic heterotrophic bacteria; and 3) enumeration, isolation, and characterization of autotrophic bacteria.

Contrary to the commonly held view that deep sediments are highly reduced and anaerobic, microbiological activity and pore-water chemistry were indicative of a relatively oxidized environment. While a diverse array of anaerobic microorganisms and associated activities were present in these layers, populations of aerobic heterotrophs dominated, which caused a more rapid mineralization of organic compounds when samples were derated than when incubated anaerobically. At all depths from 0.1 to 300 in below the surface, pore-water Eh values exceeded $200 \mathrm{mV}$ and sulfide was nondetectable, indicating the waters were not chemically reduced and that anderobic microbial metabolism was not prevalent in most of the strata sampled.

Aerobic heterotrophic bacteria ranged in population density from nondetectable $\left(<10^{2}\right)$ to $10^{7}$ per g dry weight (Figure 1), with the greatest populations occurring in sandy, water-bearing layers and the lowest populations in the clayey, low-pH layers. Colonytype analysis revealed a considerable amount of diversity, which is in contrast to the low diversity previously observed in shallow aquifer syste:ns. A number of the isolates grew under microaerophilic conditions, with many on $\mathrm{N}$-free inedia, indicating $\mathrm{N}_{2}$-fixing capdbilities. Plasinid profiles of aerobic heterotrophic bacteria were determined by gel electrophoresis. The profiles indicate that plasinid-harboring isolates are present in most of the core samples. Approximately $40 \%$ of the isolates examined (>200) carried one or more plasmids, inost of which were larger than 100 kilobases. The relative importance of plasmids in subsurface bacteria is unclear at this time. However, large plasinids in soil and aquatic bacteria code for specific physiological characteristics, such as nitrogen fixation, antibiotic and inetal resistance, and enzymes involved in the biodegradation of a number of aromatic compounds. 


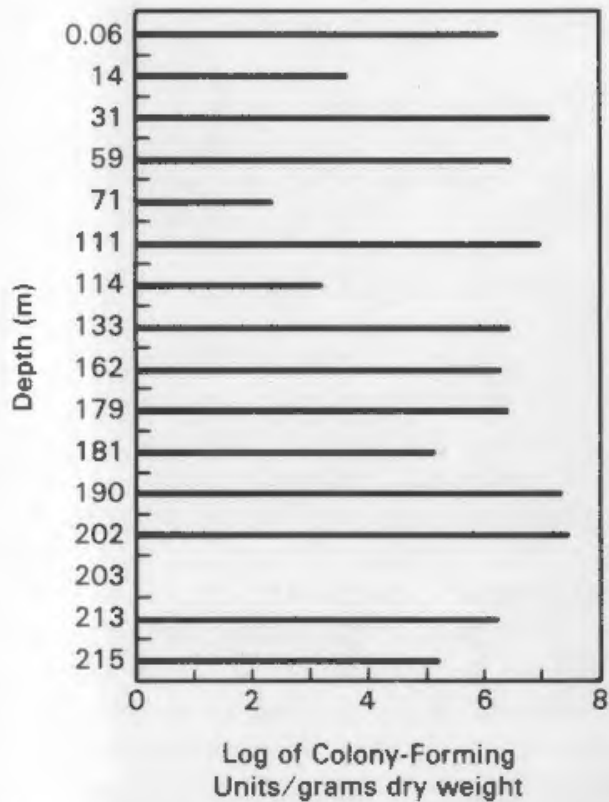

FIGURE 1. Aerobic Heterotrophic Bacteria Were Measured to Depths of $215 \mathrm{~m}$ in Subsurface Samples Taken at the Savannah River Laboratory.

Chemoautotrophic bacteria enumerated in the SRL cores included nitrifiers, sulfur, $\mathrm{H}_{2}$, manganese, methlotrophic, and iron-oxidizing bacteria. While chemoautotrophic microorganisms were detected in many of the core sam- ples, populations were generally sparse. Sulfur-oxidizing bacteria were the most numerous and most frequently encountered group, and their presence was consistent in the corresponding formations from the different cores examined. The density of nitrifying bacteria was, in general, positively correlated to pore-water ammonium and nitrate- $N$ concentrations. Manganese and $\mathrm{H}_{2}$-oxidizing bacteria, as well as methylotrophic bacteria, were observed in a number of core samples, while iron-oxidizing bacteria were observed in only one sample. Identification and isolation of these different physiological groups is continuing, in addition to statistical analysis of their relationship to geochemical parameters such as $\mathrm{pH}$, Eh, organic matter content, and ion species and concentrations. The metabolic capabilities of indigenous microbial populations were investigated by quantifying the aerobic mineralization of three ${ }^{14} \mathrm{C}-1$ abelled organic compounds: acetate, phenol, and 4-methoxybenzoate. These compounds represent a readily metabolizable organic, a model contaminant, and a model humic compound, respectively. Biodegradation of all three compounds was observed at all depths (Figure 2), although the rate and extent of degradation varied with compound structure and subsurface sample. In general,

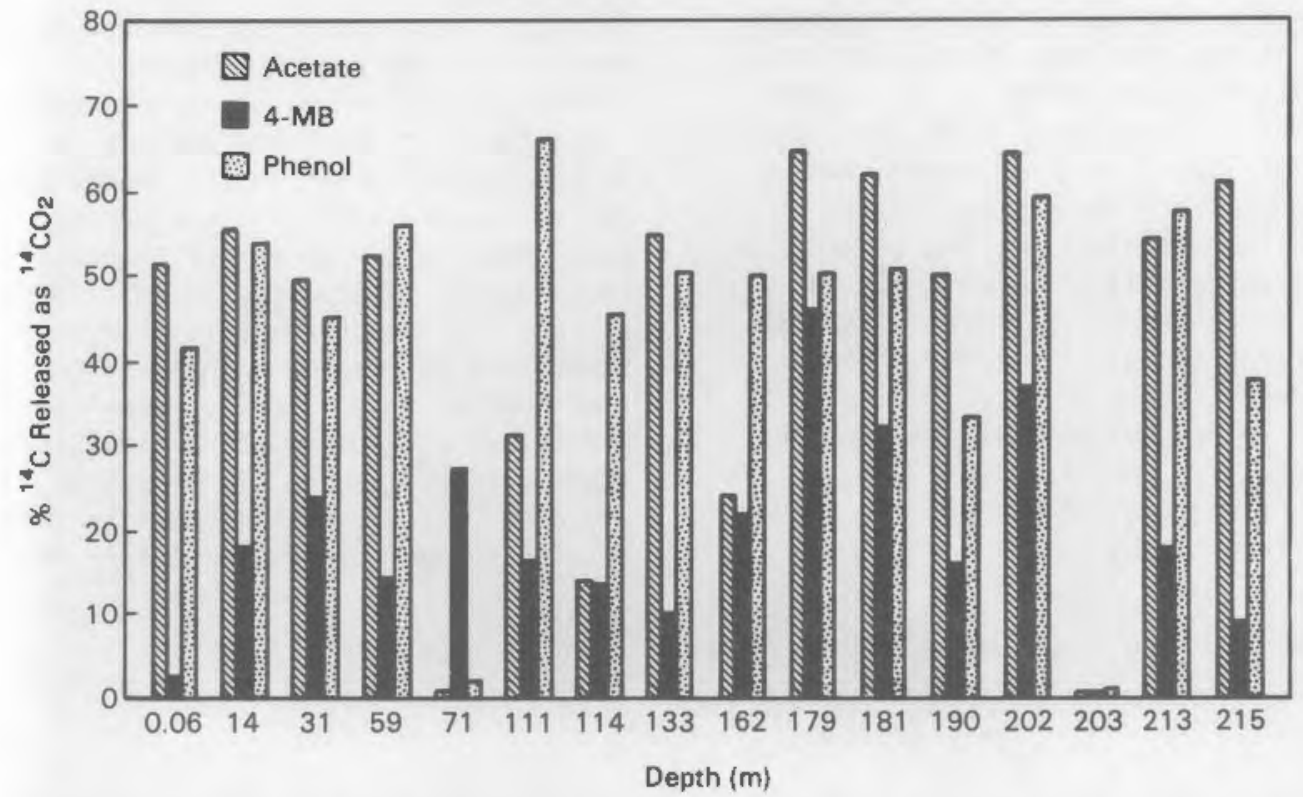

FIGURE 2. Degradation of Acetate, 4-methoxybenzoate (4-MB), and Phenol by Indigenous Aerobic Microbial Populations was Measured to Depths of $215 \mathrm{~m}$, which Includes the Tuscaloosa Aquifer, a Major Supply of Fresh Water for Domestic and Industrial Use in the Southeast. 
biodegradation in the core samples followed the order acetate>phenol>4-methoxybenzoate. These results suggest that subsurface environments (particularly deep environments) have a much higher potential for degradation of contaminants than was previous?y hypothesized.

Four bacterial species, capable of degrading acetate, phenol, and 4-nethoxybenzoate, have been isolated from the subsurface cores. Since metabolic genes for the degradation of many aromatic compounds are often carried on plasmids, initial characterization of these isolates has included examination for the presence of plasmid DNA. Each of the four isolates carries one or more large plasmids, and the plasmids in three of the four isolates are of similar size. The functions encoded by these plasmids are unknown at this time. However, they may be involved in the degradation of organic compounds, particularly the more recalcitrant aromatics. In addition, the presence of plasmids in these organisms has important implications in microbial genetic exchange mechanisms and genetic manipulation strategies. Additional experiments, using DNA:DNA hybridization methods, are planned in an attempt to elucidate the nature and function of subsurface bacterial plasmids.

These results demonstrate for the first time that there is a diverse and active microbial population in the deep subsurface, indicating that the biosphere will have to be extended from what was once believed to be the limit for microbial life (i.e., soils and shallow aquifers) to regions much deeper in the earth's mantle. In addition, the presence of microorganisms capable of degrading a variety of organic compounds and autotrophs capable of transforming inorganic nutrients and metals suggests that with improved understanding of indigenous populations and their ecology, effective in situ techniques for the mitigation of organic contaminants in the deep subsurface may be possible.

\section{FLUID DYNAMICS IN SUBSURFACE SYSTEMS}

Principal Investigator: C. S. Simmans

Associate Investigators: G. P. Streile, J. F. McBride, J. W. Cory, and R. W. Nelson

A sequential series of experiments is being performed to test the validity of fundamental scientific hypotheses that form the theoretical basis for modeling the subsurface movement of immiscible organic liquids. An intermediate-scale experimental facility is being assembled in which the subsurface flow behavior of organic chemicals will be studied. Benchmark experiments that demonstrate phenomena of immiscible multiphase flow will be performed in the facility. The experimental results will be used to support the development of validated computer models capable of predicting migration of organic chemical contaminants in aquifers. Measurements of pressure-saturation and permeability-saturation relationships for threefluid phase flows are being obtained to drive simulations of the benchmark experiments used to test scientific hypotheses. Mathematical methods are also being derived to treat miscible transport when flow occurs in heterogeneous porous media.

A PNL report (Streile and Simmons 1986) was completed that assessed the state of technological development of computer transport models for subsurface migration of organic chemicals. The study found few models adequate for predicting the movement of immiscible organic liquids in the vadose zone, where contamination problems usually originate. Moreover, a number of technical issues that suggest limitations in modeling the subsurface behavior of organic chemicals were identified and examined. The issues indicate that further advancement of modeling capability is not possible without explicit experimental clarification of immiscible flow phenomena. The report identifies areas of multiphase immiscible flow theory where both 
mathematical and experimental progress must be made to advance organic chemical subsurface transport models. We concluded that an experimental facility should be fostered to study the interactive behavior of transport, chemical sorption, and biodegradation processes in national subsurface environmental systems.

A position paper explaining the proposed experiments to be performed in an intermediatescale facility was developed. The paper discusses the scientific hypotheses on which the rultiphase flow theory for immiscible organic fluids is based. Rationalized sequences of both laboratory column and intermediate-scale experiments were described. These experiments systematically test the validity of the fundamental hypotheses, such as Darcy's flow law extended to a simultaneous movement of immiscible fluids (i.e., water, organic liquid, and organic vapor in air) in vadose zones. A collaborative research effort between university computer model developers and PNL researchers is recommended to help develop the next generation of predictive computer models. Design criteria developed in FY 1986 for the facility will be used by university scientists in FY 1987 to model the proposed benchmark experiments. These simulations will provide information needed to adjust dimensions and variables of the intermediate-scale flow cells to test research hypotheses on miscible and immiscible chemical transport. This collaborative research will be initiated by a workshop early in FY 1987.

Under a cooperative contract with Virginia Polytechnic University researchers, the basic flow properties of trichloroethylene (TCE) liquid in a sandy soil were measured. The measurements were made of two-phase fluid combinations of air-water, air-TCE, and water-TCE. The specific soil medium was formulated by PNL as a model sandy soil, and TCE was selected as an example of an organic liquid that is more dense than water but less viscous. The purpose of the experiments was to test the scaling hypothesis, which asserts that triple-phase flow behavior can be analytically deduced from flow parameters measured in two-phase subsystems. Fluid permeability-saturation relationships for all two-phase combinations were also calculated, based on a theoretical capillary conductivity model. Warranting further research is the discovery that the dynamic viscosity of TCE in a relatively inert soil is much greater than the chenical handbook tabulated value. The implication is that permeability scaling may be a more complicated phenomena than presently accounted for by the scaling hypothesis. In FY 1987, PNL researchers will examine other hypotheses about the reactivity of TCE with the presumed inert soil medium.

A technical issue of concern pointed out in the modeling capability assessment report prepared by Streile and Simmons (1986) is the mathematical treatment of porous-flow heterogeneity. Models that predict the migration of immiscible organic chemicals in groundwater must aiso be able to describe the miscible transport of the soluble portion of the contamination. With that objective, two research papers describing a stochastic mathematical extension of classical deterministic miscible transport theory were prepared for journal publication. This work was also presented (Simnons 1986) at the Sixth Annual American Geophysical Union Hydrology Conference in Colorado and at the Gordon conference on modeling flow in permeable media at Andover, New Hampshire, on July 30, 1986.

The mathematical expression of Darcy's flow law, in terms of a scaler flux potential, neglects the local rotational contributions important in heterogeneous media. This research is investigating the rotational components of flow when the porous medium is heterogeneous rather than homogeneous, as is often conveniently assumed. It was found that for a mathematical representation including both nonrotational (scaler flux potential) and rotational (vector flux potential) aspects of flow, the conventional minimum kinetic energy theorem for irrotational flow no longer applies. A technical note prepared for submission to Water Resources Research Journal will highlight these theoretical mathematical findings.

\section{REFERENCES}

Simmons, C. S. 1986. "A Generalization of One-Dimensional Solute Transport: A Stochastic - Convective Flow Conceptualization." In Proceedings of Sixth Annual AGU Front Range Branch Hydrology Days, H. J. MorelSeytoux and J.W. Warner, eds. Fort Collins, Colorado, pp. 139-151. 
Streile, G. P., and C. S. Simmons. 1986. Subsurface Flow and Transport of Organic Chemicals: An Assessment of Current Modeling Capability and Priority Directions for Future Research (1987-1995). PNL-6043, Pacific Northwest Laboratory, Richland, Washington.

\section{FUTURE RESEARCH}

Future subsurface transport research will evaluate the influence of organic surface coatings on contaminant binding, using carefully selected subsurface materials, their clay fractions, and three multi-ring $\mathrm{N}$-containing organic compounds of various hydrophobicities. Forward and backward sorption rates will be evaluated in disaggregated aquifer materials to probe the diffusion of organic contaminants into and out of organic coatings and microparticulate organic material. Investigations will begin to probe the relationship between sorption and microbiologic degradation. Initial experiments will be performed in static systems with representative mineral surfaces and microbial isolates of specific degraders. These studies will progress to aquifer materials and water-saturated columns where physical (diffusion, mass flow), chemical (sorption), and microbiological (degradation) effects are integrated. Collectively this research will advance understanding of contaminant transport in groundwater by carefully elucidating the contributions of different controlling processes.

Other experiments will focus on the degradation of one- and two-ring, N-containing, aromatic compounds (nitrobenzene, aniline, pyridine, quinoline, and aminonaphthalene) under aerobic and anaerobic conditions to obtain relative biodegradation kinetic information. 'In addition, these experiments will create conditions that will aid in the isolation of specific contaminant degraders to be used to probe sorption-biodegradation relationships, and help elucidate the relative importance of co-contaminants and natural substrates in the degradation of these compounds. 
Marine Sciences 


\section{- Marine Sciences}

PNL research in the marine sciences is focused on geochemical cycles and the molecular, biochemical, cellular, and organismic responses of marine animals to the combined effects of environmental stress and infectious diseases. Studies utilize newer PNL capabilities in probing for specific gene transcripts (which may encode for stress-response proteins) in conjunction with long-established expertise in marine chemistry. This combined capability is being applied in investigations that both probe the interactions of geochemical and biological processes, and establish the genetic basis for globally distributed diseases that affect the ability of marine mussels to physiologically transport and tolerate metal contaminants.

MARINE CHEMISTRY OF ENERGY-RELATED CONTAMINANTS

\section{E. A. Crecelius and J. S. Young}

In this and previous studies, PNL has quantified the concentrations and sources of soluble and particulate metals in Puget Sound waters. This information serves as the foundation for other studies that will identify the geochemical processes controlling the concentrations and biological availability of metals to aquatic organisms. Results of the research will be used to determine the upper limits of contaminant exposure that organisms and ecosystems can safely tolerate. This information can be used in monitoring such activities as ocean dumping, harbor dredging, and industrial discharges.

\section{Bioavailability of Copper to Mussels Exposed} to Contaminated Suspended Sediment

PNL studies have shown that marine organisms bioaccumulate dissolved copper, and that the presence of dissolved organic matter reduces the bioavailability of copper by complexing the copper onto sediment particles. In marine waters near industrial and urban centers, the concentration of particulate copper in the form of suspended sediment can be greater than that of dissolved copper. The objective of these experiments was to compare the bioavailability of dissolved copper with copper adsorbed onto suspended sediment. Mussels (Mytilus edulis) were exposed for a month to flowing, raw seawater in six aquaria. To two of these aquaria, sediment containing an ambient copper concentration of $20 \mu \mathrm{g} / \mathrm{g}$ dry weight was continually added to maintain a suspended load of approximately $4 \mathrm{mg} / \mathrm{L}$. The dissolved and particulate copper concentrations were 0.27 and $0.026 \mu \mathrm{g} / \mathrm{L}$, respectively. To the second pair of aquaria, sediment that had been amended to contain $600 \mu \mathrm{g} / \mathrm{g}$ copper was continually added to maintain a suspended load of approximately $4 \mathrm{mg} / \mathrm{L}$. The dissolved and particulate copper concentrations were 1.4 and $1.6 \mu \mathrm{g} / \mathrm{L}$, respectively. To the third pair of aquaria, dissolved copper was continually added, resulting in dissolved and particulate concentrations of 3.1 and $0.15 \mu \mathrm{g} / \mathrm{L}$, respectively. After a month of exposure, 20 mussels from each aquarium were dissected, and the gills and other soft tissue were analyzed for copper. The concentrations of copper in the gills were as follows: $10.4 \mu \mathrm{g} / \mathrm{g}$ dry wt for mussels exposed to ambient copper, $31 \mu \mathrm{g} / \mathrm{g}$ for mussels exposed to copper-amended sediment, and $208 \mu \mathrm{g} / \mathrm{g}$ for mussels exposed to dissolved copper. These results indicate the relatively low bioavailability of sedimentbound copper compared to dissolved copper.

\section{Silver in Marine Mussels}

Roesijadi et al. (1984) found that the gills of mussels living in or transplanted to metal-contaminated waters near Tacoma, Washington, accumulated up to 65 times more silver than the gills of mussels from a pristine environment. In addition, recent results of NOAA Status and Trends (Mussel Watch), a program which analyzes pollutants in mussels from clean and impacted marine waters from around the United States, have revealed increased tissue levels of silver in mussels from urban areas. The gills of bivalves serve as an uptake site for some metals; the metals are eventually transported to the kidney, sequestered in small granules, and excreted with the urine. The purpose of this investigation was to see if silver, which can be highly toxic, behaves in a similar manner.

For this experiment, mussels (Mytilus edulis) were exposed to a continuous flow of $5 \mu \mathrm{g} / \mathrm{L}$ silver in seawater for 2 weeks. They were then dissected and selected tissues were prepared for analysis of silver concentration by flameless atomic absorption spectrophotometry 
(AA) and X-ray microanalysis (XM). Samples for $A A$ analysis were freeze dried, weighed, and digested in nitric acid. Samples for XM were fixed in phosphate-buffered glutaraldehyde containing $\mathrm{Na}_{2} \mathrm{~S}$ and $\mathrm{NaCl}$. They were embedded in Spurr's resin without postfixation, sectioned at $90 \mathrm{~nm}$, and mounted unstained on beryllium grids. They were examined by scanning transmission electron microscopy (STEM) on a JEOL 1200 EX analytical electron microscope equipped with an $X$-ray detector and a Tracor Northern 5500 multichannel analyzer.

The mean silver concentrations of 10 mussels examined by $A A$ were $2.17 \mu \mathrm{g} / \mathrm{g}(\mathrm{SD}=1.69)$ in the gills and $0.72 \mu \mathrm{g} / \mathrm{g}(\mathrm{SO}=0.80)$ in the remaining tissues. Gills and kidney were examined by XM. Silver was found as sparse electron-dense particles in the gill epithelium and in some kidney granules. The only metal found in most of the granules was zinc, which normally accumulates in the kidneys. The granules that contained only silver or silver mixed with zinc were morphologically different from the zinc granules (Figures 1 and 2). This preliminary experiment suggests that one of the processes used by mussels to handle silver is to store it in kidney granules.

\section{REFERENCE}

Roesijadi, G., J. S. Young, A. S. Drum and J. M. Gurtisen. 1984. "Behavior of Trace Metals in Mytilus edulis During a Reciprocal Transplant Field Experiment." Mar. Eco. Prog. Series 18: 155-170.

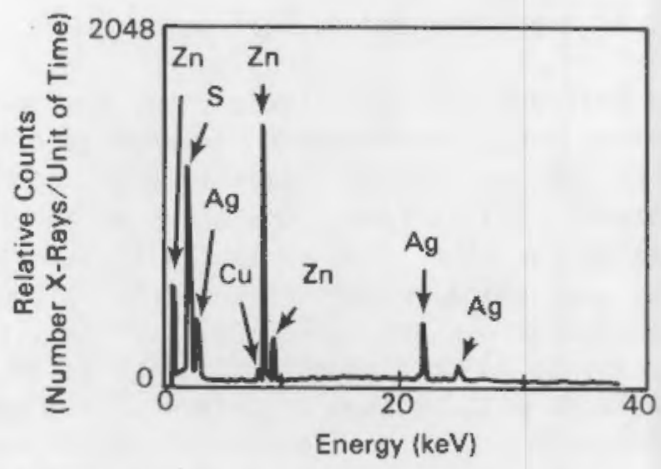

FIGURE 2. X-Ray Microanalysis Spectrum of the Larger Aggregated Dark Bodies in the Left Half of Figure 1. Sulfur was a component of the fixative; copper is found in trace amounts in tissues.

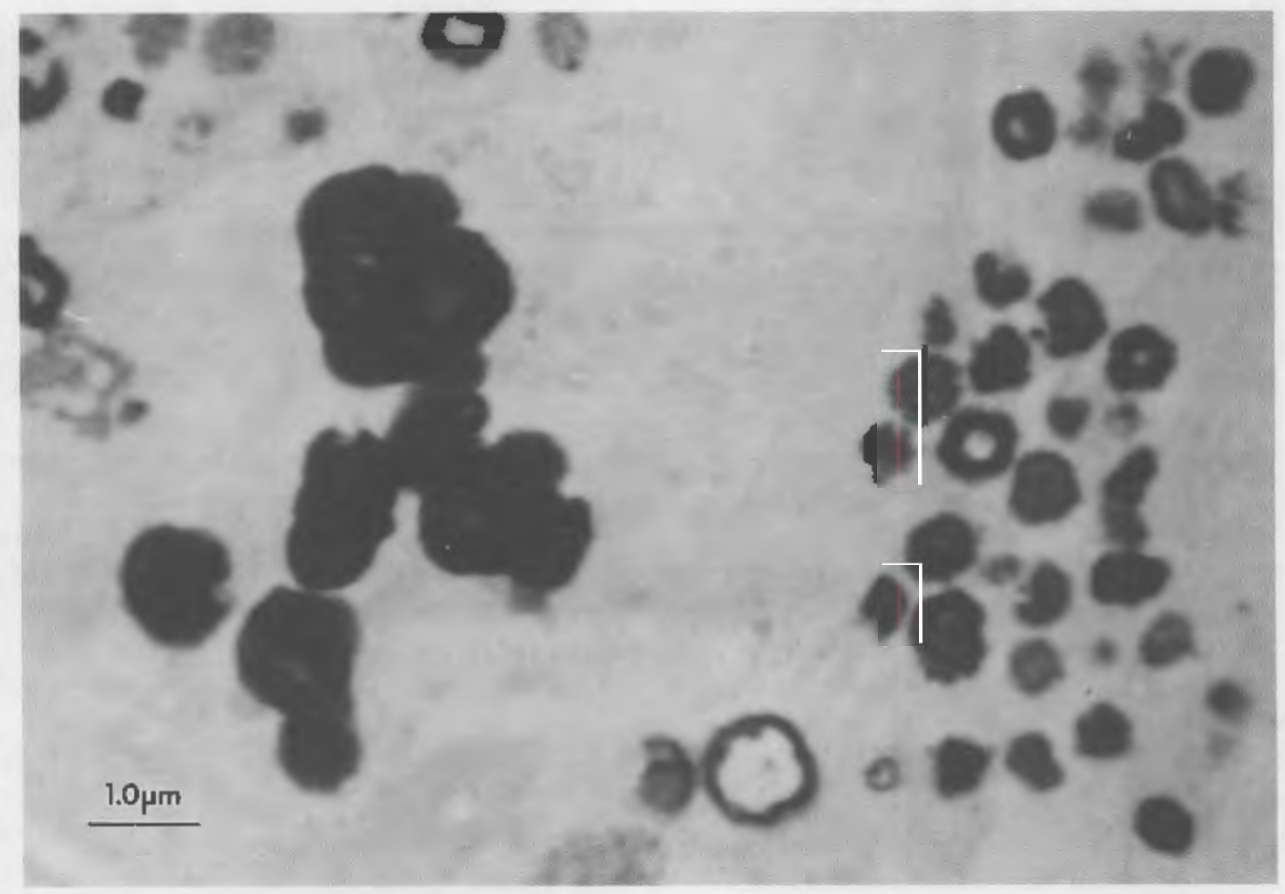

FIGURE 1. Scanning Transmission Electron Microscopy Photograph of Mytilus edulis Kidney Granules. The larger granules in the left half contain both silver and zinc; the smaller granules on the right contain only zinc. 
ENVIRONMENTAL STRESS AND DISEASE IN MARINE ANIMALS

R. A. Elston

The objectives of this research are to identify specific infectious disease phenomena in marine animals, and to characterize the molecular, biochemical, and cellular bases for the diseases and their modulation. In addition, the program addresses the effects of environmental stresses on the immune systems of marine animals. It has been necessary to identify and select a number of naturally occurring candidate diseases that are suitable for more detailed study. Consequently, the research for the past year has focused on identifying which infectious diseases are most suitable for the molecular and biochemical studies now beginning.

In Vitro Characterization of Cadmium Effects on Salmon Disease

This continuing study investigated the effects of cadmium on the ability of an obligate intracellular pathogen of salmon to infect salmon cells in vitro. Research described earlier defined the toxicity threshold of the tissue culture cells for cadmium and accomplished the intracellular isolation of a unique pathogen (Rosette Agent) of the salmon. Once these methods were standardized, the interactive effects of cadmium and the pathogen on the tissue culture cells were investigated. Preliminary results suggest that the addition of $10 \mu \mathrm{m}$ cadmium to the cell culture medium increases the infectivity rate of the pathogen. These studies were terminated, however, in favor of the use of other invertebrate models of disease and environmental stress, which are reported below and are more promising for the proposed studies on molecular and biochemical mechanisms of disease.

Proliferative Disease in the Bay Mussel and Its Effects on Metal Accumulation

Pacific Northwest Laboratory discovered this disease in Washington State and documented that local populations contain the highest incidence that has been recorded of proliferative disease, a blood cell disorder. The occurrence of the disorder in up to $46 \%$ of the individuals in natural populations is associated with high levels of mortality in these populations. This mollusk disease has been selected as a principal focus for further studies.

In 1986 in vitro methods were developed to remove affected tissue from a mussel and maintain the tissue in a cell culture for up to 6 weeks. Using histological and blood cell diagnostic techniques, the natural prevalence of the disease was documented and it was determined that during certain seasons of the year the disease completely eliminates reproductive development in the mussels. Currently, monoclonal antibodies to normal and affected cell populations are being developed; these monoclonal antibodies will be used to probe for cell surface proteins that are specifically induced in the stressed or diseased state. In addition, blood cell collection and diagnosis methods are being used to collect the tissue used in examining for novel gene transcripts that could code for stress-induced proteins. Expression of these transcripts will be compared with the monocional antibody probes developed for cell surface proteins.

Experiments were also conducted to characterize the consequences of the blood cell disease on the ability of mussels to transport metals through their blood stream and accumulate these metals in their tissues. The results of these experiments are currently being analyzed.

Fatal Immunodeficiency in the Flat Oyster

This year PNL identified in local waters an oyster disease identical to a disease that has decimated the same species of oyster in Europe. PNL scientists also identified a local stock of oysters with a resistance factor of about $75 \%$ to the disease, a fatal deficiency of the immune system. In order to evaluate this disease as a candidate for further studies, transmission criteria for the disease in the laboratory were established and highly susceptible, disease-free stocks of oysters were identified. These studies have provided a base for the use of this disease model in molecular and biochemical studies, but further information on defining the resistance phenomenon in individual oysters is needed. A graduate student (M.S.) project at the laboratory was begun to facilitate further studies. 


\section{Specific Proteases from Marine Myxobacteria}

In another project involving a graduate student, marine myxobacteria that have specific proteolytic activity for oyster ligament proteins were identified, isolated, and characterized. These bacteria were identified in oyster hinge ligaments where they cause liquefaction of the ligament, which kills the oysters. Isolation of the bacteria led to in vitro studies, which showed that the bacteria have a highly specific proteolytic activity for the ligament protein; this proteolytic activity is not found in other bacteria. In addition, research found that these bacteria could use the oyster ligament as a sole source of organic carbon and nitrogen for their proliferation (Figure 1). Thus, these myxobacteria contain the genetic information for enzymes that may have a variety of research and industrial applications.

\section{Oyster Fatal Inflammatory Bacteremia}

This year another study involving a collaborative graduate research project on fatal inflammatory bacteremia of oysters was begun. The prevalence of this disease increases from near zero in undisturbed environments to almost $30 \%$ in "stressful" environments, characterized by relatively low levels of seawater exchange, high temperatures, and high levels of primary productivity. The disease may be responsible for the oyster mortality rates of $30 \%$ or higher that are annually observed. Studies completed this year have tentatively identified the causative bacterium as an actinomycete and may have isolated the organism. Continuing work is aimed toward verifying the isolate, characterizing it biochemically and molecularly, and studying the disease pathogenesis.

\section{FUTURE RESEARCH}

Future research in marine sciences will focus on the behavior of metals, examination of how environmental stress modulates disease in marine animals, and the underlying molecular, biochemical, and cellular basis for this modulation. In addition, the consequences of disease and stress will be examined at the organismic level. For example, continuing studies on the mussel blood cell disease will elaborate unique gene transcripts present in the disease condition and the expression and function of resultant stress-related proteins at the cellular level. The studies will also examine how the differential expression of stress protein affects cellular function, such as the polymerization of actin and myosin filaments. These studies will also be expanded to examine both the diseases' consequences at the organismic level and stress, which may induce or enhance the diseases. Thus, the laboratory's traditional strengths in marine chemistry will be used to evaluate

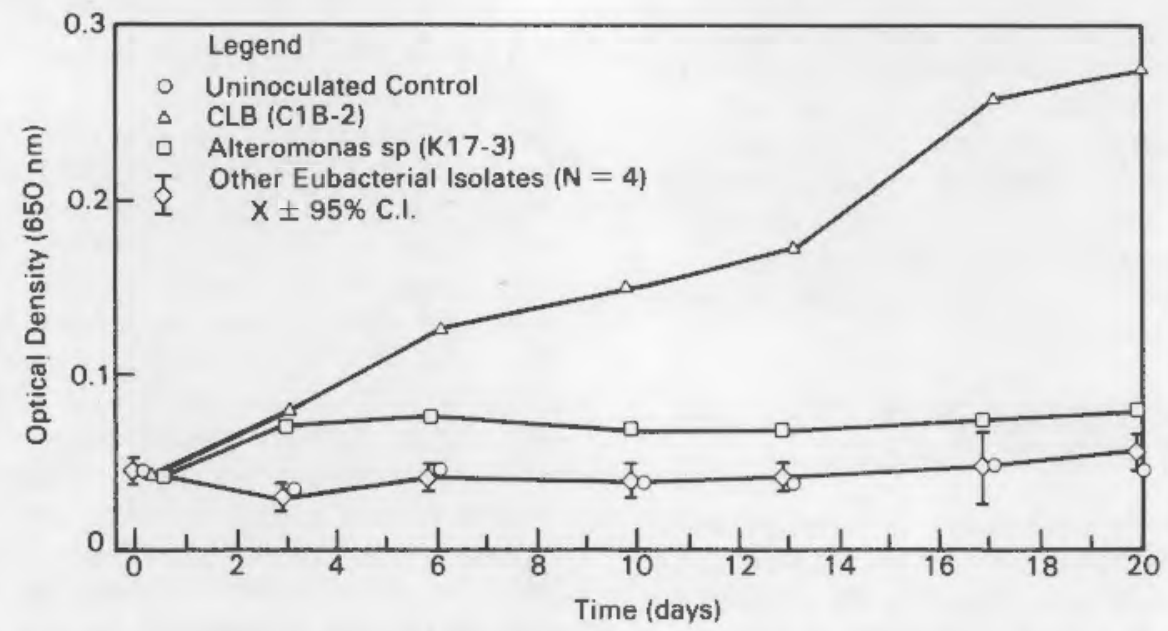

FIGURE 1. Growth of Marine Myxobacterium (CLB) Using Oyster Ligament as a Sole Source of Organic Nitrogen and Carbon, in Comparison with the Growth of a Variety of Typical Marine Bacteria Which Cannot Enzymatically Degrade the Ligament. 
the effect of stress-induced disease on the physiological transport and degradation of environmental pollutants.

To make maximum use of knowledge developed on the existing programs, PNL will build on the current interdisciplinary approach by adding staff in the fields of molecular biology, physiology, chemistry, and genetics. Specialized equipment is needed for isolation of DNA/RNA, synthesis of genes, and application of recombinant DNA techniques. The combined additional support would markedly accelerate progress in the protection, management, and pharnaceutical use of valuable marine species. 


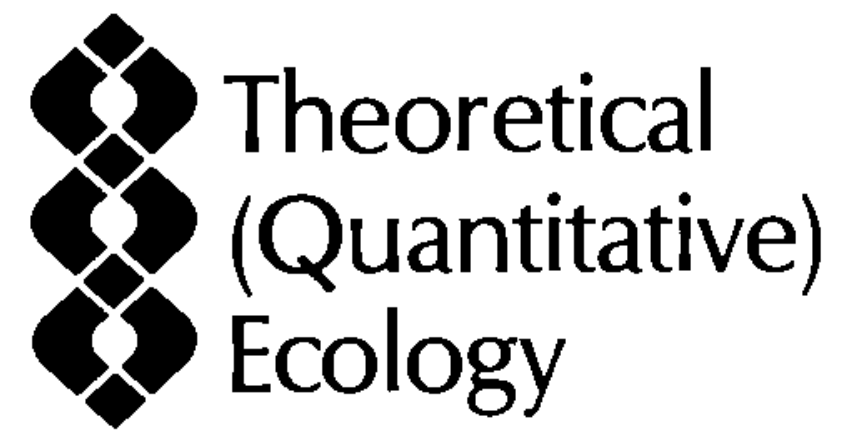




\section{- Theoretical (Quantitative) Ecology}

Field studies in ecology are often limited by the lack of suitable designs for sampling contaminants and populations in time and space. Particularly difficult areas of recent concern are in subsurface microbiology, global change, and hazardous wastes. This program is partially directed toward adapting concepts from other fields, such as geostatistics, to meet these needs. This entails mathematical advances as well as hypothesis testing with data developed in field studies. Similarly, standard experimental designs, demographic theory, and methods of statistical estimation are generally not applicable for estimating the influence of natural and man-induced stresses on wildlife and fish populations. Such needs are particularly manifest at the large DOE sites in the West.

Several major new statistical approaches have been developed with the program for understanding how populations react to environmental change. Examples of these approaches are:

- replacing the general, restrictive assumptions previously required in modeling survival curves with assumptions that are specific to a population

- using comparative population dynamics to simplify the equations used and data required in modeling net maternity

- adapting methodologies to design ecosystem studies that optimize data-gathering methods.

\section{DYNAMICS OF WILD POPULATIONS}

L. L. Eberhardt

For a number of years, this research has been concerned with large manmal population dynamics, in particular population regulation, a major unresolved issue in ecology. Population regulation problems will probably not be resolved simply by mechanistic appraisals of ecological system components. Furthermore, opportunities for understanding population regulation are weakened with each new human impact. Most of the work has to be done through cooperative studies with management agencies and takes many years to complete. Thus, to address immediate problems, this research has focused on the top of the trophic levels, using field data to understand the forces regulating large animal populations.

In the current year, work continued on the Yellowstone grizzly bear, a species classified as "threatened" under the Endangered Species Act and impacted by energy development. The research includes estimates of abundance and certain essential population parameters, such as reproductive and survival rates. Various kinds of models have been used in an effort to assess the available data. One such model is based on a simpledifference equation, and was developed to assess data on population trends and mortality. Some inconsistencies in the trend data were demonstrated, which may be useful in devising research and management strategies (Eberhardt, Knight, and Blanchard 1986).

Various facets of the grizzly bear study can best be developed by using data from other populations of large bears; therefore, PNL scientists have been in contact with investigators in Alaska and Canada. For instance, work on polar bears demonstrates some intriguing differences in reproductive patterns anong these populations, which we believe may be largely caused by a temporary shortage of the bears' principal food supply, ringed seals. This data may shed light on how the grizzly bear food supply in Yellowstone, compared to the food supply in Alaska and Canada, causes differences in reproductive patterns between grizzlies in Yellowstone and elsewhere. However, one of the major difficulties in assessing how data, such as changes in food supply, affect population regulation is the lack of suitable survival estimates. To resolve this, we have been working on methods for using age structure data to evaluate survivorship, and we expect to continue these investigations in more detail. The problem is to replace the restrictive assumptions (stationarity of population trend and constant annual recruitment) currently required in estimating survival with assumptions that can be approximated for each population modeled.

In general, solution of the survivorship problem requires additional information on 
population trends. Therefore, investigations are continuing into ways of incorporating age structure and population trend data into a common framework, which will probably involve iterative computer-based evaluations of simple population dynamics models with a chisquare criterion.

New concepts were developed which allowed a great simplification of models of the "net maternity curve" (a product of reproductive rates and survivorship) so that the population dynamics of several species can now be compared. While such curves are useful for theoretical purposes and with large data sets, they severely limit efforts to incorporate population trend data, age structure, and reproductive and survival rates in practical models of actual populations. A possible solution is to truncate the net maternity curve and thus replace a rather complicated equation with a much simpler version. An example (Figure 1) uses data on the northern fur seals of the Pribilof Islands. Figure 1 shows how a complex equation containing six unknowns [Equation 8 as given in Eberhardt (1985)] can, under appropriate conditions, be replaced by:

$$
y=f 1_{a} s^{x-a}
$$

where $y=$ net maternity, $f=$ annual reproductive rate, $1_{a}=$ survival to age at first reproduction, $s=$ annual adult survival, $x=$ age, and $a=$ age at first reproduction.

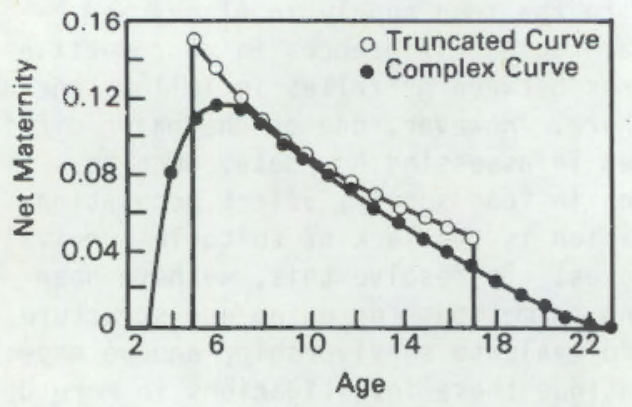

FIGURE 1. Complex Net Maternity Curve for the Pribilof Fur Seals, Compared with an Approximation Produced by Truncating the More Complex Curve.

\section{REFERENCES}

Eberhardt, L. L. 1985. "Assessing the Dynamics of Wild Populations." J. Wildl. Manage. 49(4): 997-1012.

Eberhardt, L. L., R. R. Knight, and B. M. Blanchard. 1986. "Monitoring Grizzly Bear Population Trends." J. Wildl. Manage. 50(4):613-618.

\section{QUANTIFYING ENERGY-RELATED EFFECTS ON MOBILE SPECIES}

J. R. Skalski, M. A. Simmons, D. S. Robson, * and M. Kosorok**

Temporal and spatial variability is common to all natural systems. The elusive and secretive nature of mobile species makes the detection of these changes all the more difficult because direct observations and measurements are not feasible. Hence, population studies incorporate all the design and analysis problems of other environmental investigations, plus the paraneter estimation difficulties encountered in dealing with wild populations. In addition, advances in sampling sessile components of the environment (i.e., plants, soil, air, and water) cannot always be directly transferred to the study of mobile species. However, the statistical methods for mobile species often provide a general framework for the broader class of environmental analyses.

Research during the past year has focused on issues specific to wild populations, as well as environmental investigations in general. Research on design optimality for tagrecapture studies was extended to the design of studies that use indices to estimate abundance. In turn, these index studies are analogous to the design of soil or plant ecology investigations. Survival analysis of clinical data was also extended to the more general case of analyzing lifetime data for free-ranging populations. In both index and survival analysis, the statistical framework

*Biometrics Unit, Cornell University, Ithaca, New York.

**Department of Statistics, Brigham Young

University, Provo, Utah. 
includes as special cases an analysis of more traditional biological or ecological data.

Design Optimality

The magnitude of environmental noise and the high costs of investigating mobile species almost ensures that unless a study is designed efficiently it will not be effective. As such, a major goal has been the publication of a Wildlife Monograph that details the statistical and programmatic approaches to optimizing the design of wildlife investigations. This methodology indicates, for instance, that the optimal size of study plots and intensity of sampling effort change with the overall objectives of the investigation. For instance, the optimal study plot size in a comparative census of animal abundance between habitats is twice as large as the optimal plot size for a single-plot demographic study of equal precision. The incorporation of such findings can make the difference between a successful and an unsuccessful field experiment.

An investigation of the statistical basis of wildife index studies indicates an analogy to the design of multiple-plot agricultural studies with subsampling. The variance structure of this field design is nonparametric in form and has broad applicability to environmental sampling whenever subsampling is employed. Optimality procedures were developed and computer programmed for this field design, which can be used not only in the study of mobile species but also in plant ecology studies and physical/chemical characterization of the environment. Intil now, the optimization of tests of effects had been considered an unsolved statistical problem (Scheffe 1959).

Survival Analysis

Among the most important demographic parameters in the regulation of wild populations is the survival rate(s). In classical survival analyses, the objective is to relate the probability of survival against possible mortality factors by following individual case histories through time. In wildlife investigations, individual case histories are typically unavailable and inferences concerning survival and causality must be based solely on records of surviving individuals. For instance, survival rates of migratory waterfowl are estimated from the recovery rates of banded individuals surviving to a given sampling period, while the fate of the nonrecovered birds remains a mystery. A formal theory for relating environmental conditions to the estimated survival rates of waterfow 1 does not exist and, consequently, the inferences concerning population regulation are both subjective and speculative. Similar interests exist with other wild populations and how their fates may be influenced by man's activities, such as energy production. It is for these reasons improvements in survival analysis are important.

We are researching ways of incorporating the theory of survival analys is with current methods of estimating the survival rates of wild populations. Again, using the example of migratory waterfowl for illustration, covariates could be incorporated in the band recovery analysis to determine the possible influences of environmental factors, hunting regulations, or other human activities on the annual survival of the species. One model being investigated is the exponential regres sion model, where survival (s) to time $t$, given a particular set of covariates $(x)$ [for example $S(t) \mid x)]$, is expressed as

$$
s(t \mid \underset{\sim}{x})=s_{0}(t)^{e^{-x \beta}}
$$

Here, the conditional survival rate, given $\underset{\sim}{x}$, is simply a function of baseline survival $\left[S_{0}(t)\right]$ raised to the power $e^{-x}$. Equation (1) is also known as the proportional hazards model in risk assessment. This survival model (1) can be readily incorporated into tag-recapture procedures to provide estimates of the regression coefficients (ß). Similarly, Tikelihood ratio tests can be constructed to test the significance of particular explanatory variables such as air emission data, climatic factors, disease incidence, or changes in resource use on the observed survival rates of wild species. Equation (1) is a special case of the more general class of survivorship given by the Weibull regression model

$$
s(t \mid x)=e^{-\left(x^{\beta} t\right)^{\delta}}
$$

(where $\delta=$ the shape parameter), which has been shown to fit a wide range of survivorship curves (Figure 1) of human and animal populations. Results of this basic research will increase the sensitivity of ecological 


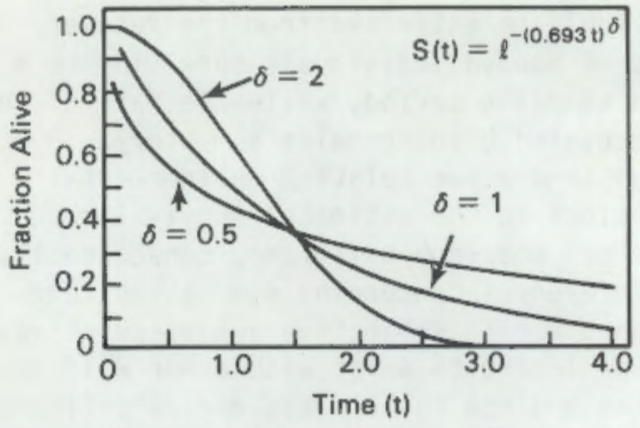

FIGURE 1. Alternative Shapes of Survivorship Curves Based on a Weibull Regression Model and a Change in the Value of $\delta$. For $\delta=1$, the survivorship curve is an exponential decay model with a half-life of $S(t=1)=0.5$.

studies in detecting natural and humaninduced perturbations in mobile species before such effects are reflected by large decreases in population levels.

\section{REFERENCE}

Scheffe, H. 1959. The Analysis of Variance. Wiley, New York, $477 \mathrm{pp}$.

\section{DESIGNS FOR ENVIRONMENTAL FIELD STUDIES}

\section{J. M. Thomas and L. L. Eberhardt}

A shortcoming of current field studies in ecology and environmental science is that some study objectives cannot be evaluated experimentally. Suitable designs for several classes of sampling have been developed in fields other than ecology, and are thus largely unknown to ecologists and environmental scientists. Hence, one emphasis has been on adapting methodology developed in other fields, such as geostatistics and industrial research. This ranges from further development of the "superpopulation" concept as a way to provide a framework for analytical sampling (in community and ecosystem studies) to computer searches for optimal sampling times and distances, used in kinetic models that describe the movement of trace materials (heavy metals, radionuclides, pesticides, and other environmental contaminants).

The prospects for conducting true, ecological experiments (without pseudoreplication) are not good without major methodological innovations. Thus, some of this research was focused on areas where existing data and circumstances might allow statistical hypothesis testing. A high potential for true replication was found to be available, using data from long-term studies or surveys conducted on state game management units. Thus, it is possible to statistically test hypotheses about populations, thereby settling questions rather than just endlessly discussing the data. This research shows that the simplest surplus-yield models may be used as the basis for the null hypotheses of formal statistical tests of density-dependent population regulation. One caution is that the more interesting hypotheses, such as the interaction of resources with population regulation, cannot yet be tested with these surplus-yield models. Current quantitative research also indicates that much of the needed work lies in the realm of the biologist, who can help statisticians avoid errors caused by failure to account for field conditions, and who can also provide life histories for individual species.

In an attempt to provide a quantitative basis for the use of indices in ecological surveys, a study was conducted of the accuracy obtained when indices were estimated via double sampling. Double sampling (related to ratio estimation) is a statistical technique often mentioned in survey sampling texts. However, the technology has been largely ignored in the environmental sciences and the assumptions have not been tested for circumstances peculiar to these areas.

A paper was prepared that describes the initial effort to assess the prospects for calibrating indices by using either ratio estimation or double sampling. Seventeen sets of data were assessed in checking that the approximations imposed by the need to utilize the ratio of two random variables are valid for ecological work. Moreover, since measurement errors are often a serious factor in environmental studies, as opposed to human demographic research, simulations were used to check the effect of measurement errors on estimates of animal population means and variances. Double-sampling methodology was demonstrated to be a cost-effective way to calibrate indices of population size.

Theoretical ecology scientists also participated with other staff in the planning of the 
"DOE Arid and Semi-Arid Lands Research Program." As a result of that study and research on sampling for pattern, two collaborative field projects were initiated. In the first joint study, soil samples were obtained near the dripline of replicate sagebrush plants. Several forms of nitrogen, as well as measures of $\mathrm{pH}$, Eh, moisture, and organic carbon, were recorded as a function of depth and compass direction. This information will be used in an ongoing multilaboratory study designed to determine the response of arid ecosystems to water and nitrogen amendments. Results of surface (0 to $2.5 \mathrm{~cm}$ ) soil tests indicate a strong directional component for organic carbon, nitrate, and ammonia (Figure 1) concentrations. These results are consistent with movement of surface litter (the primary initial source of carbon and nitrogen) via wind (there were no significant directional differences for other parameters, including moisture), and indicate that measurements obtained during the multilaboratory experiment may need to be adjusted to allow for directional differences. In addition, the coefficients of variation were found to be less than $5 \%$ for Eh and $\mathrm{pH}$, between $20 \%$ and $30 \%$ for organic carbon and nitrate, $39 \%$ for ammonium ion, and $70 \%$ for nitrate. Comparable data will soon be available for the 2.5to $5.0-\mathrm{cm}$ soil horizon. Clearly, sample sizes needed to detect treatment differences will be parameter-dependent.
In another collaborative experiment (designed by Or. John Skalski), the spatial distribution of plant cover and soil particle size over the ALE Reserve was statistically modeled. The study required a special geometric sampling design as well as measurements on plots of various sizes. The major objective in deriving empirical relationships for important spatial-variance phenomenon is to use these data to suggest field designs for future hydrologic and plant ecology studies. A second goal is to develop analytic solutions that describe the spatial variance phenomenon. Such fundamental statistical models could be used at other sites.

\section{FUTURE RESEARCH}

Future research in these projects will focus on:

- developing new, highly innovative sampling approaches to allow precise estimates of contaminant inventories, patterns of dispersal, and evaluation of the success of remedial measures

- devising new quantitative methods to explain population dynamics based on age structure data from populations undergoing change, and

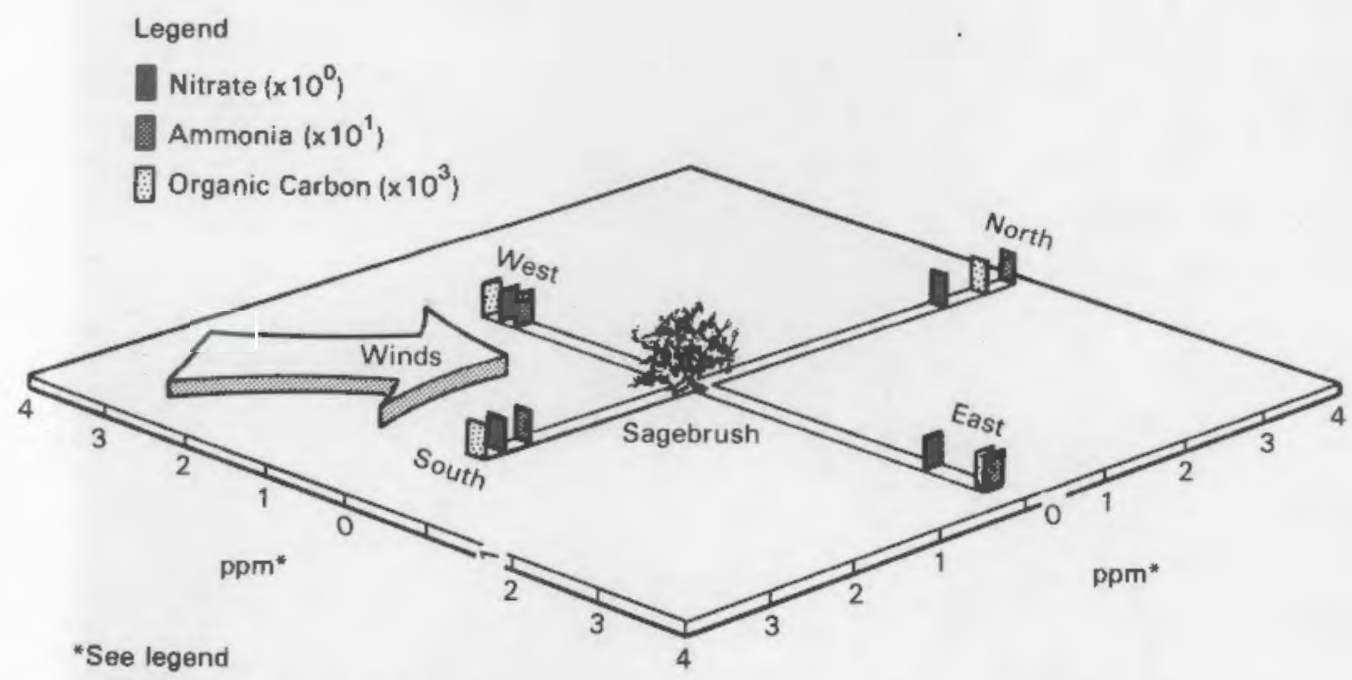

FIGURE 1. Organic Carbon, Ammonia and Nitrate Concentration ( $\rho \rho m)$ in $0-$ to $2.5-\mathrm{cm}$ Soil Cores as a Function of Direction Around Sagebrush ( $n=6$ ). 
- continued specialized investigations of improving study designs and survival analyses for mobile species.
The basic research currently under way, as well as that projected for the near term, will lay the foundation for attaining these longer-term goals. 


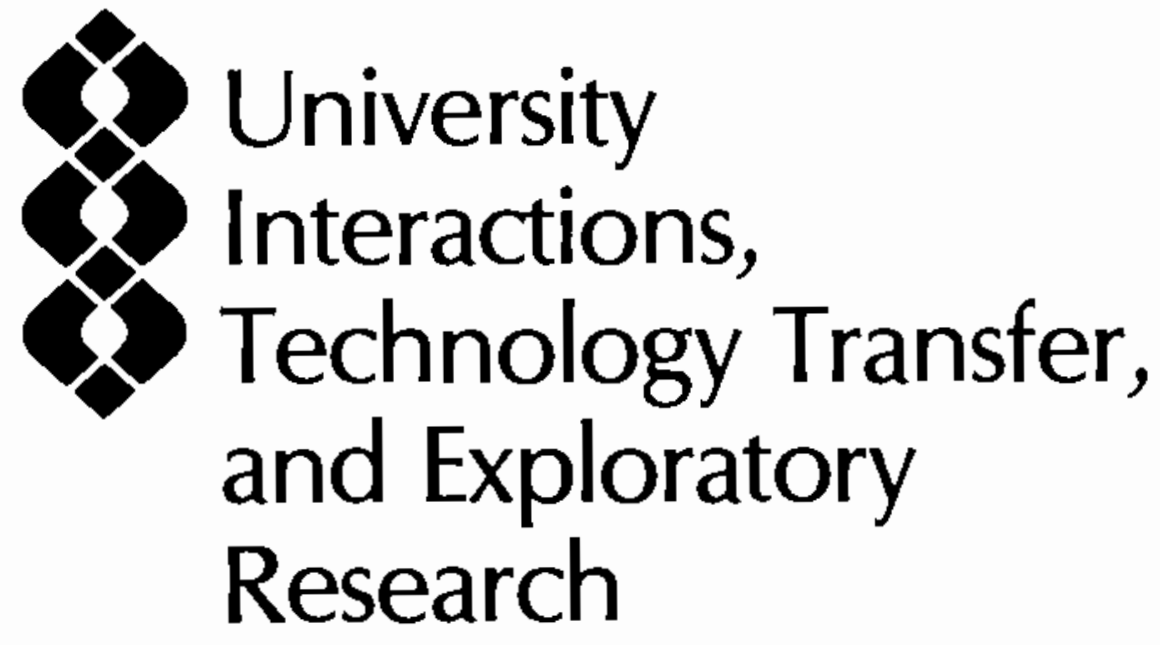




\section{- University Interactions}

PNL scientists recently formulated a proposal to form a Laboratory Science Education Center under the auspices of the Department of Energy. The Education Center is aimed at making the scientific resources of the laboratory more available to students and faculty from the university and pre-university communities. The Environmental Sciences programs have for many years served as a model for these types of interactions, with active university collaboration on every project. However, new emphasis is being placed on expanding the participation of educational institutions in research planning and implementation, and use of unique PNL facilities. The latter represent a major resource and include advanced biogeochemical laboratories, the National Environmental Research Park at Hanford, the Marine Research Laboratory at Sequim, the Aerosol Research Center, the Arid Land Watershed Facility, and the new Intermediate-Scale Subsurface Transport Facility.

The PNL university program is administered through the PNL Office of External Affairs on a cooperative basis with the Northwest Organization for Colleges and Universities for Science (NORCUS) in the Tri-Cities Universities Center (TUC).

During FY 1986, overall laboratory support to the universities was significantly increased. This included direct support via subcontracts and indirect support to NORCUS for stipends to allow student and faculty participation at PNL. In addition, several new collaborative relationships were developed under a Collaborative Agreement between PNL and Washington State University (WSU). The new agreement includes provisions for the appointment of selected university faculty as PNL Affiliate Staff Scientists (PASS), with full privileges of access to and use of PNL facilities. Joint planning is also under way for the development of a physical facility to house and better integrate these cooperative activities with other ongoing educational activities of both PNL and TUC. Under the new PNL/WSU Collaborative Agreement, Dr. David Bezdicek, Professor of Soil Science at WSU, was awarded a PASS appointment in the Environmental Sciences.

Twenty university faculty members, 2 postdoctoral scientists, and 30 graduate students working on dissertations participated in PNL's ongoing projects in FY 1986. Their work covered a wide range of topics in earth and environmental sciences, including geo* chemistry, geohydrology, biotechnology, remote sensing, soil physics, meteorology, ecology, wildlife biology, and atmospheric chemistry. In FY 1986 these university collaborative studies resulted in eight research papers published and two dissertations filed. In addition, four research papers are pending with publishers, and two new dissertation studies commenced in FY 1986. Citations are in the Publications and Presentations Section.

In addition to university faculty and graduate students, the Center also provided opportunities for "hands-on" experience to 36 student trainees (third and fourth year college). The Environmental Sciences Department also hosted 34 visiting scientists during FY 1986 as part of the research and review of OHER programs.

\section{NATIONAL ENVIRONMENTAL RESEARCH PARK}

The National Environmental Research Park (NERP) provides a mechanisin for university environmental scientists and their students to interact with PNL scientists and to ut $i$ lize PNL facilities and NERP lands for their research. Student research at the Pacific Northwest Laboratory has primarily focused on the ecological sciences and has provided information critical to the long-term use of large areas of undeveloped land on the Hanford site.

Currently, 19 dissertation studies on ecological topics are $i$ n progress, providing opportunities for students to combine realworld experience in environmental sciences with their formal training. Examples of this research include studies of elk, coyote, Canada goose, and bald eagle populations. Student research also includes population studies of the response of two plant species (Lupinus sulfureus and L. leucophyllus) in relation to long-term vegetative recovery following wildfire.

Although the current NERP program is quite active in regard to faculty and graduate stident participation and sponsorship of 
dissertation studies in the ecological sciences, future plans call for expansion of both the scientific scope and types of activities to be undertaken. This expansion should significantly broaden the NERP scientific program into new topical areas and should significantly increase recognition of Hanford NERP activities and facilities within the scientific community. Topical areas scheduled for increased emphasis are within the Atmospheric Sciences, Geosciences, and Environmental Sciences.

Available for student use at PNL are state. of-the-art research equipment, logistics support, and mentoring. Students are encouraged to publish the results of their studies in peer-reviewed scientific journals.

\section{SUBSURFACE MICROBIOLOGICAL TRANSPORT PROGRAM}

The PNL Subsurface Transport Program continues to have strong ties with the university community, with university scientists functioning both as technical advisors and collaborators. Technical advisors to the program review research plans for laboratory and intermediate-scale experiments and suggest alternative and possibly more fruitful approaches where necessary. Several university research groups possessing unique expertise are collaborators on the PNL program as subcontractors to strengthen fundamental research in specific scientific areas germane to subsurface transport. Collaborative research is also under way with other university scientists who are funded separately by the DOE/OHER Subsurface Transport Program. Major new interactions occurred in FY 1986 through the consortia of laboratory and uni. versity scientists participating on the first joint subsurface microbiological sampling effects at Savannah River Laboratory. Joint research with the university sector will expand as the PNL program extends experimenta? efforts into multiphase transport and microbial phenomena and progresses from basic scientific research in the laboratory to largerscale experiments in the intermediate-scale facility and the field. Currentiy, the collaborative relationships exist with the following universities: Purdue University, Princeton University, University of Florida, California Institute of Technology, Stanford University, University of Notre Dame, Auburn University, University of Virginia, University of Oklahoma, Cornell University, Massachusetts Institute of Technology, Pennsylvania State University, and University of Illinois.

\section{OTHER INTERACTIONS}

Pacific Northwest Laboratory staff members hold affiliate or adjunct apoointments at a number of universities, and contribute to the universities' educational programs directly and through the Tri-Cities University Center in Richland, Washington. Approximately twothirds of the TUC teaching staff are scientists and engineers from PNL, including 14 senior staff members from the Earth and Environmental Sciences Center. 


\section{- Technology Transfer}

Research for non-DOE federal agencies and for industry offers the opportunity to both develop new technology in the environmental sciences, and apply existing talent in solving practical problems. Contract arrangements between DOE and Battelle Memorial Institute provide unique avenues at PNL for problem solving and technology transfer.

A brief synopsis of representative examples of technology transfer are outlined below by major program area.

\section{DETECTING AND MANAGING CHANGE IN TERRESTRIAL ECOSYSTEMS}

For the Departinent of Defense (Army), two major studies are continuing on the characterization of army smoke aerosols and smoke effects on vegetation, using the advanced instrumentation available in the PNL wind tunnel facility. Nonintrusive particle characterization by the new laser optical technique is being successfully applied to several smokes, and the facility has now been modified to bring under control the extremeiy wide range of environmental conditions needed to determine the effects on vegetation of these complex, polydisperse aerosols. Recently, studies were initiated at the Yakina Firing Center to develop a means for the rapid assessment of envirommental damage associated with Army training activities. This research is based on proven sampling techniques deveioped at Hanford, coupled with advanced computer analysis and remote sensing techniques available at PNL. Additional work for the Department of Defense includes the development of bioassessment techniques to evaluate the relative biotoxicity and sources of chemicals at open-burning/open-detonation sites. Advanced statistical approaches developed on DOE programs are being utilized to define the distribution of pollutants over large areas of firing ranges.

\section{BIOGEOCHEMICAL PHENOMENA}

Pacific Northwest Laboratory has been conducting a long-term study for the Electric Power Research Institute (EPRI) on chenical reactions that occur in coal combustion waste materials, soil, and the groundwater aquifer, and that control the dissenination of inorganic contaminants. The work focuses on measuring precipitation and adsorption reactions that immobilize chemical constituents in wastes and the subsurface.
Thermodynamic and kinetic descriptors of these phenomena are being developed at the mechanistic level for inclusion in reactionbased transport codes. The work will eventually provide EPRI and nember at ilities with rigorous scientific data and models to forecast contaminant movernent and devise effective disposal and mitigation strategies where needed.

For NRC, efforts are under way to develop sampling strategies and models for prediction of biological transport of radionuclides from low-level waste disposal sites. This witl allow validation of models developed in part by OHER. In other studies for NRC, a project to be completed in FY 1987 is examining the effect of excretory products from tree roots in mobilizing soil-dispersed radioactivity, extending capabilities initially developed by OHER to define radionuclide complexation by extracellular soil microbial metabolites.

For the EPA-Corvallis Environmental Research Laboratory, three new projects have been initiated. The first is directed toward development of a "microcosm" test system for evaluating the transport, fate, and effects of genetically engineered microorganisms (GEM). The second project is designed to evaluate the relative importance of the routes of pesticide exposures to wildlife. The third project is evaluating hydrogeochem. ical models used to estimate the effects of acid rain on watersheds. The $P N L$ wind tunnel has been modified to address this concern. In other work for EPA, the PNL environmental staff will continue to aid in planning exercises on acid rain and global change research, and will be providing technical guidance for ocean dumping of low-level radioactive wastes, identification of screening models for dose assessment, and technical guidance for Superfund activities in Region $x$. 


\section{MARINE SCIENCES}

Information from the Marine Chemistry program on sedimentation rates and the distribution, sources, and fate of contaminants in Puget Sound is being used by NOAA, EPA, and local regulatory agencies to plan cleanup strategies for the Puget Sound region.

Work on a DOE-sponsored program on the effects of environmental stress and disease on marine organisms has yielded results with practical significance for the regional, and possibly worldwide, shellfish industry. This program required that we characterize a 10cally occurring disease of the flat oyster. The disease is caused by an obligate intracellular pathogen of immune cells, and thus causes a fatal immunodeficiency in the oyster. It was first discovered that this disease is bonamiasis, which has nearly eliminated production of the flat oyster in France and the Netherlands and has spread to England, Ireland, Denmark, and Spain, with devastating effects on the shellfish industry in Europe. It was also determined that the disease spread to Europe from a North American source. Perhaps most significantly, a locat stock of oysters has been identified which seems to have acquired a substantial degree of resistance to the disease. Needless to emphasize, these discoveries have been of great interest to the governmental agencies concerned with shellfish diseases and the local industry, both of wich have a keen interest in the eradication and management of this disease in Pacific Northwest waters. The Washington Department of Fisheries requested technical advice on eradication or management of the disease in Washington and on methods to evaluate various oyster stocks for the presence of the disease. The discovery of a strain resistance to the disease may have worldwide significance to the culture of the flat oyster.

In work for the Army Corps of Engineers, studies will continue on the effects of dredging at several locations in Puget Sound, including effects on the behavioral responses of crabs. Research will also be undertaken to identify the hydrochemical causes of fish toxicity observed in new Snake River hat.cheries.

Field studies were conducted of the coast of California for the Pacific Outer Continental
Shelf Jffice of the Minerals Management Service to examine how sound emissions from geophysical survey operations might affect the commercial fishery for rackfish. Both in situ behavioral experiments and experimental fishing were done to discern the effects of air-gun sounds on rockfish behavior and fishing success. The statistical design of the experimental fishing used concepts and techniques developed in the DOE-sponsored research on assessing impacts on populations of mobile species.

Studies are under way for the Alaska Office of NOAA $/ O A D$ on the effects of petroleum contamination on the spawning migrations of Pacific salmon. In the first year of work, laboratory studies have shown that salmon can detect petroleum hydrocarbons at low concentrations. Additional laboratory work and/or field tracking experiments are planned for $F y$ 1987.

A series of studies are under way for the Seattle District of the U.S. Army Corps of Engineers on the environmental impacts of the Grays Harbor Navigation Improvement Project. Other work for the Grays Harbor Project has included reporting on the ocean surveys conducted by MRL to select ocean disposal sites, a series of studies to assess potential impacts to the Dungeness crab, and the deve1opment of plans for management and monitoring of the ocean disposal sites off Grays Harbor, Washington.

Studies for the National Cancer Institute are under way to determine if early embryonic exposure of fish to organic environmental contaminants results in the subsequent appearance of cancer in the fish. Other studies are utilizing marine invertebrates as models for the development of cancer in humans and are addressing fundamental biological mechanisms at the molecular and biochemical level.

Studies have been conducted to evaluate the importance of the sea-surface microlayer as a site for emryogenesis of valued marine species, and to determine the current levels and biological effects of sea-surface contamination in Puget Sound. The sampling and analysis methods developed under this project may provide a model for evaluating seasurface contamination in other areas. 
The MRL also ajjed in designing a field survey of juvenile lingcod in the Grays Harbor estuary. The statistical design and analysis benefitted from concepts developed in the DOE-sponsored research on populations of mobile species.

\section{THEORETICAL (QUANTITATIVE) ECOLOGY}

The publication of a PNL wildife monograph by the Wildiffe Society will make available to the public a myriad of statistical approaches to optimizing wildi ife investigations. Based on this research, environmental impact studies can be designed so that the probability of success will be known in advance.
Basic research on vertebrate population dymamics has resulted in techniques and models that allow use of limited data for decisions concerning both endangered species and normal management activities.

The U.S. Army has recentiy begun to use DOEsponsored research results on survey designs to define the potential environmental hazards caused by open burning and detonation at their ammution plants.

Fundamental ideas on compositing samples, developed under the OHER quantitative ecology program, are being used by other Hanford con* tractors in an attempt to provide more costeffective worker radiation exposure surveillance. 



\section{- Exploratory Research}

PNL is committed to major investments of discretionary resources on basic science programs. Direct investments were made in the Environmental Sciences as well as in those areas that strongly support efforts in environmental sciences, including advanced analytical technology, molecular biology, geologi$\mathrm{cal}$ modeling, hazardous chemical/mixed wastes, and advanced computational methods. The investments should have long-term impact on the scientific depth and quality of research throughout the laboratory.

Expioratory research investments in the Environmental Sciences for FY86 reflected, in part, the new directions and goals of these programs.

DETECTIUN OF GENETICALLY ENGINEERED
MICROORGANISMS

3. K. Fredrickson

Recombinant DNA technology holds many promises, but there is also concern over the release of any genetically engineered microorganisms (GEMs) into the environment, whether deliberate or accidental. Risk assessment requires careful monitoring of GEMs once released. Research at PNL has established capabilities for detecting GEMs and determining their fate and potential hazards to the ecosystem. To achieve this, model GEMs were constructed by inserting transposable genes into soil bacteria for use as identifiers. A rapid most-probable-number procedure, used in conjunction with DNA hybridization, was able to detect the mode? GEMs in several soil types at a sensitivity equal to or greater than presently available methods. Our procedure could detect selected genetically modified bacteria at densities of less than 10 per $g$ ( 1 cell in $10 \%$ ), although for less-easily cultured bacteria the sensitivity was diminished. This technology has been used directly in research funded by the EPA; with further refinement it will be a candidate for technology transfer. Future research will include refining methods of DNA hybridization to increase the sensitivity and specificity of environmental detection of GEMs. In addition, PNL scientists have made presentations to private companies and the U.S. Army to discuss the potential of this technology for such uses as monitoring agricultural applications and verifying the Biological Warfare Treaty. This technology might also be used for developing in situ toxic waste biodecontanination processes. For instance, the present capabilities could help in determining the survival and effectiveness of bacteria genetically engineered to degrade environmental pollutants.

REMOTE AEROSOL MEASUREMENT FOR WIND TUNNEL TESTS

M. W. Ligotke

Environmental wind tunnels can provide opportunities to investigate the interactions of gaseous and particulate pollutants in simulated natural conditions. Formation, transport, fate, and effects of air-suspended particles are studied by scientists at PNL to provide new understanding of the ways man influences his environment. Of controlling importance in these investigations is the need to accurately measure the concentration, particle size, and chemical composition of the airborne contaminants studied in wind tunnel tests. Previously used methods of obtaining these data required that physical probes be placed within the test canopy. This method often led to inaccurate measurements, caused by limitations of the probes in collecting suspended particles, or from disturbance of the air flow by the probes thellselves. One method of avoiding these problems, a remote laser particle analyzer, was modified and demonstrated in the wind tunnel of the PNL Aerosol Research Facility.

An existing laser particle spectra analyzer (LPSA) was set up to propagate a helium-neon laser beam through the transparent walls of the PNL wind tunnel and to receive the light scattered from particles passing through a specific portion of the laser beam. The LPSA was positioned on a three-dimensional track to allow rapid focusing of the system's

"viewing volume" at most locations within the 
20-ft-long wind tunnel test section. The particle-scattered pulses of light were converted to an electrical signal via a photovoltaic processor and then analyzed to provide information on particle size and concentration.

The LPSA was shown to be practical for providing information on air-suspended particle characteristics in plant canopies, above soils, and close to other environmental surfaces. In addition, the system may provide information quickly and accurately on the resuspension of particles from surfaces, such as mill tailings and storage piles. Future work will measure a wider range of particle sizes and the addition of computer contro? for faster and more accurate focusing.

REHOTELY ACQUIREO THERMAL DATA FOR ENERGY EXCHANGE IN ARID REGIONS

P. A. Beedlow

The objectives of this exploratory research are to determine how data from the Landsat 5 satellite can aid our understanding of the energy exchange processes affecting the heat and water balance of arid ecosystems, and to develop techniques to measure those processes over large regions. The data collected in FY 1986 will address these objectives more specifically by 1) producing a calibrated and verified map of soil and canopy temperatures for Hanford (such a map is key to calculating energy budget parameters), and 2) developing and validating a model to predict latent heat flux from soil and canopy temperature data (this model is necessary for calculating energy budget components from sateliite data).
During FY 1986, our research brought together an interdisciplinary team of scientists from the geophysics (G. E. Wukelic and J. E. York), Hydrology (G. W. Gee and R. L. Skaggs), and Terrestrial Sciences (S. 0. Link) sections of PNL, and D. F. Gibbons of Fort Lewis College, Durango, Colorado. This team has identified areas of joint research that are not only key to this effort, but that also contribute to the development of their respective disciplines.

I.andsat 5 scenes of Hanford were acquired for single days in October 1985, and May, June, and July 1986. Rawinsondes were flown, and ground truth data (soil and canopy temperature, reflectance, and soil moisture) were gathered for reference points within the Hanford landscape on each of the overflight days. Micrometeorological stations were established to collect complete energy budget data at reference points for the Landsat 5 overflight days. Prelininary analyses indicate that temperature resolution on the order of $0.6^{\circ} \mathrm{C}$ is attainable for water bodies when the thermal data are corrected for local atmospheric effects (the resolution potential of Landsat 5 is $0.5^{\circ} \mathrm{C}$ ).

Research proposed for FY 1987 will focus on establishing the relationships between satellite data and basic parameters of the energy budget for arid landscapes. Beyond FY 1987, research will address other key landscape processes, possibly including a new research program to develop methods using satellite data for measuring evapotranspiration from arid landscapes. 


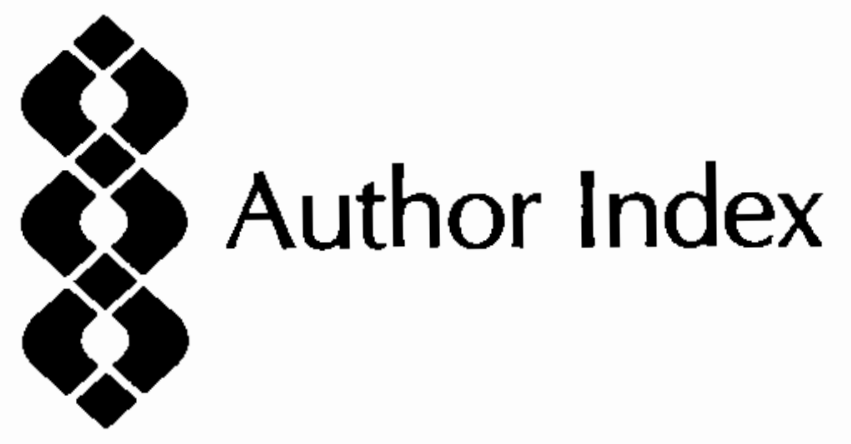




\section{AUTHOR INDEX}

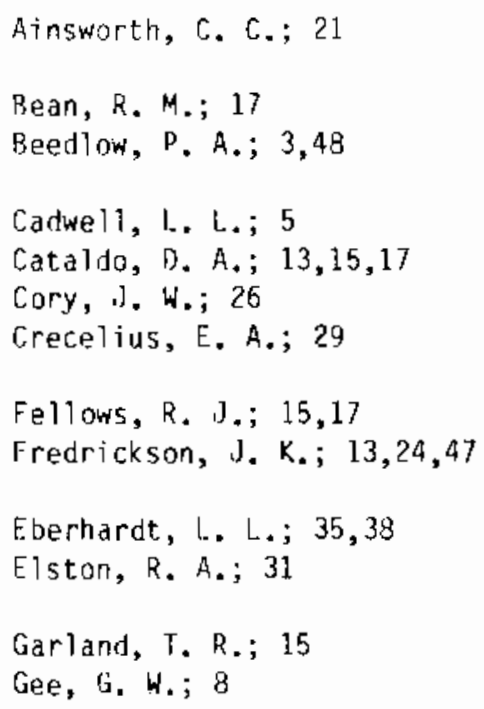

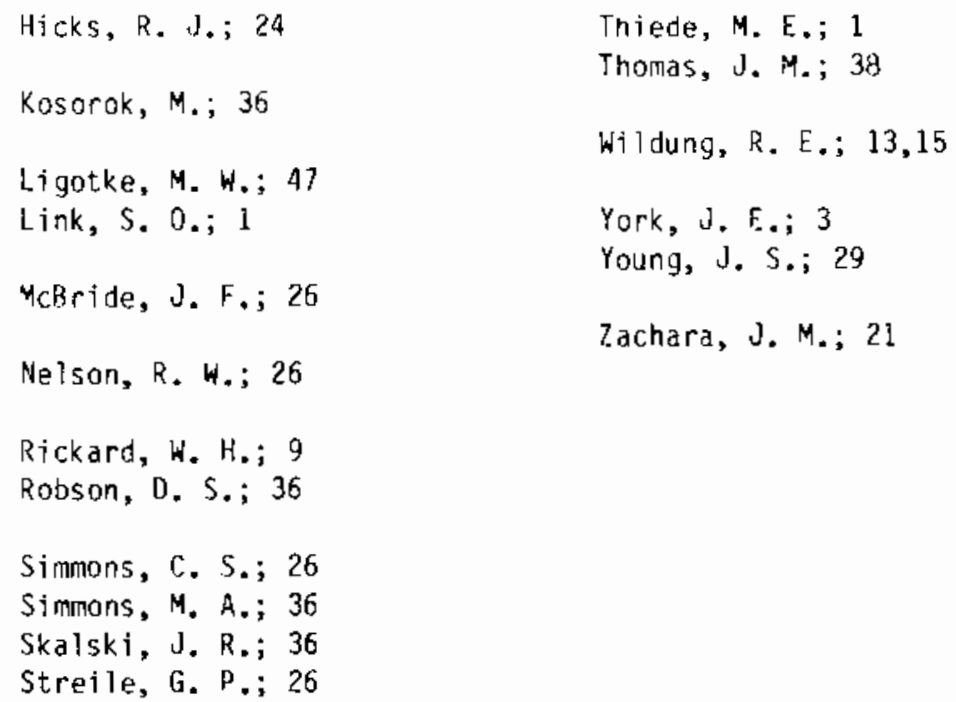





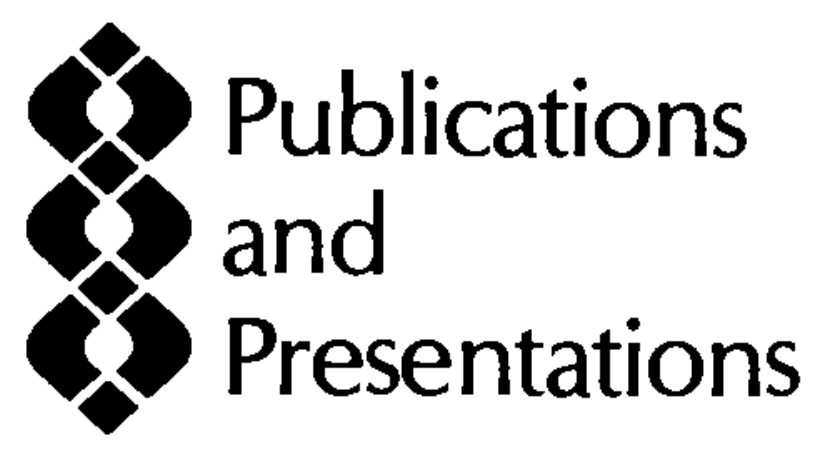




\section{PUBLICATIONS}

\section{Arid Land Sciences}

Becker, C. D., D. A. Neitzel and D. W.

Carlile. 1986. "Survival Data for Dewatered Rainbow Trout (Salmo gairdneri Rich.) Eggs and Alevins." J. Appl. Ichthyol. 3:102-110.

Beedlow, P. A., D. S. Daly and M. E. Thiede. 1986. "A New Device for Measuring Fluctuations in Piant Stem Diameter: Implications for Monitoring Plant Responses." Environ. Monitor. Assess. 6:277-282.

Books, G. G. 1985. "Avian Interactions with Mid-Columbia River Water Level Fluctuations." Northwest Sci. 59:304-312.

Crabtree, R. L., F. G. Burton, T. R. Garland, D. A. Cataldo and W. H. Rickard. 1985. "Carnivore Studies: A New Individual Marking System." In Proceedings of the Fourth International Theriological Congress, Edmonton, Alberta, Canada.

Eberhardt, L. E., and L. L. CadweTT. 1985. "Radio-Telemetry as an Aid to Environmental Contaminant EvaTuation of Mobile Wildlife Species." Environ. Monitor. Assess. $5: 283-289$.

Gee, G. W., and M. D. Campbell. 1986, "Installation of Monolith Lysimeters at an Arid Site." In Abstracts, Annual Meeting of the Soil Science Society of America (in press).

Knight, R. L., and R. E. Fitzner. 1985. "Human Disturbance and Nest-Site Selection in Black-Billed Magpies." J.Field Ornithol. $56: 155-157$.

Link, S. O., and M. M. Caldwell, 1985. "Whole-Plant Photosynthesis and Transpiration of Bunchgrasses and Sagebrush when in Competition." In Proceedings of 38th Annual Meeting of the Society for Range Management (Abstract).

Link, S. 0., M. M. Caldwell and J. R. Richards. 1986. "Seasonal Whole Plant Gas Exchange Dynamics of Artemisia tridentata, Agropyron spicatum, and Agropyron desertorum." In Proceedings of IV International Congress of Ecology (Abstract).
McCorquodale, S. M. 1985. The Ecology of E1k (Cervus elaphus) in the Shrub-steppe of Washington. M.S. Thesis, University of Washington (W. H. Rickard onsite advisor).

McCorquodale, S. M. 1985. "Archeological Evidence of Elk in the Columbia Basin." Northwest Sci. 59:192-197.

McCorquodale, S. M. 1986. "Elk Habitat Use Patterns in the Shrub-Steppe of Washington." J. Wildl. Manage, 50:664-569.

McShane, M. C., and R. H. Sauer. 1985. "Comparison of Experimental Fall Burning and Clipping on Bluebunch Wheatgrass." Northwest Sci. 59:313-318.

Rickard, W. H., and D. G. Watson. 1985. "Four Decades of Environmental Change and Their Influence upon Native Wildlife and Fish in the Mid-sijumbia River, Washington, U.S.A." Environ. Conserv. 12:241-248.

Rogers, L. E., and J. M. Lee. 1985. "Ecological Effects of Extremely Low Frequency Electric and Magnetic Fields." In Assessments and Viewpoints on the Biological and Human Health Effects of Extremely Low Frequency (ELF) Electric Fields, ed. D, R. Boem, pp. 267-294. American Institute of Biological Sciences, Washington, D.C.

Van Voris, P., P. A. Beediow, S. 0. Link, D. A. Cataldo, L. E. Rogers and G. E. Wukelic. 1986. "Remote Detection of Ecological Stress from Satellite, Aircraft, and Integrated Hand-held Radiometers." In Abstracts, Society of Envirommental Toxicology and Chemistry (SETAC) Annual Meeting (in press).

Biogeochemical Phenomena in Indirect Exposure Pathways

Bean, R. M., D. D. Dauble, B. L. Thomas, R. W. Hanf and E. K. Chess. 1985. "Factors Affecting Bioabsorption, Metabolism, and Storage of Organic Compounds by Aquatic Biota." In Heaith and Environmental Research on Complex Organic "ixtures, eds. R. H. Tray, E. K. Chess, P. J. Yellinger, R. G. Riley and D. L. Springer, 24tin Hanford Life Sciences Symposium, Octoher 21-24, 1985, Richland, Washington. National Technical Information Service, Springfield, Virginia (in press). 
Bean, R. M., D. D. Dauble, B. L. Thomas, R. W. Hanf, Jr. and E. K. Chess, 1985. "Uptake and Biotransformation of Quinoline by Rainbow Trout." J. Aquat. Toxicol. 7:221-239.

Cataldo, D. A., R. M. Bean and R. J. Fellows. 1986. "Uptake and Fate of Xenobiotics in Plants." In Proceedings of the 2nd Annual DOE Contractor Meeting: Health and Environmental Effects of Complex Chemical Mixtures. CONF-8606161, U.S. D0E/OER, Washington, D.C., National Technical Information Service, Springfield, Virginia.

Cataldo, D. A., R. M. Bean and R. J. Fellows. 1985. "Uptake and Fate of Phenol, Aniline, and Quinoline in Terrestrial Plants." In Health and Environmental Research on Complex Organic Mixtures, eds. R. H. Gray, E. K. Chess, P. J. MeTlinger, R. R. Riley and D. L. Springer, 24th Hanford Life Sciences Symposium, October 21-24, 1985, Richland, Washington. National Technical Information Service, Springfield, Virginia (in press).

Cataldo, D. A., T. R. Garland and R. E. Wildung. 1986. "Neptunium Behavior in Plants: Absorption, Distribution, and Fate." In Proceedings of Sixth Workshop on Environmental Research for Actinide Elements, ed. J. Pinder. National Technical Information Service, Springfield, Virginia (in press).

Cataldo, D. A., T. R. Garland and R. E. Wildung. 1986. "Plant Root Absorption and Metabolic Fate of Technetium in Plants." In Technetium Behavior in the Environment, eds. G. Desmet and C. Myttenaere, pp. 265-280. Elsevier Applied Science Publishers, London.

Cataldo, D. A., T. R. Garland and R. E. Hildung. 1986. "Speciation of Trace Elements in Plants and Bioavajlability to Anima1s: An Overview." J. Environ. Qual. (accepted).

Cataldo, D. A., K. M. McFadden, T. R. Garland and R. E. Wildung. 1986. "Radionuclide Complexation in Xylem Exudates of Plants." In

Speciation of Fission and Activation Products in the Environment, eds. R. A. Butman and J. R. Cooper, pp. 398-408. Elsevier Applied Science Publishers, London.

Cowan, C. E., E. A. Jenne and R. R. Kinnison. 1986. "Methodology for Determining the Rela- tionship Between Toxicity and the Aqueous Speciation of a Metal." In Proceedings of the Aquatic Toxicology and Environmental Fate 9th Symposium, American Society for Testing and Materials, Philadelphia, Pennsylvania (in press).

Dauble, D. D., R. M. Bean and D. W. Carlile. 1986. "Uptake, Distribution, and Elimination of Dietary Quinoline by Rainbow Trout (Salmo gairdneri)." Comp. Biochem. Physiol. (in press).

Dauble, D. D., R. H. Gray, A. J. Scott and B. L. Thomas. 1985. "Relationship Between Solubility and Toxicity of Cool Liquefaction Materiais to the Freshwater Crustacean, Daphnia magna." In Health and Envi ronmental Research on Complex 0rganic Mixtures, eds. R. H. Gray, E. K. Chess, P. J. Mellinger, R. G. Riley and D. L. Springer, 24th Hanford Life Sciences Symposium, 0ctober 21-24, 1985, Richland, Washington. National Technical Information Service, Springfield, Virginia (in press).

Dauble, D. 0., 0. C. Klopfer, D. W. Carlile and R. W. Hanf, Jr. 1985. "Usefulness of the Lipid Index for Bioaccumulation Studies with Daphnia magna." In Aquatic Toxicology and Hazard Assessment: Eighth Symposium. ASTM STP 891, eds. R. C. Palmer and D. J. Hansen, pp. 350-358. American Society for Testing and Materials, Philadelphia, Pennsylvania.

Dauble, 0. 0., R. H. Gray, J, R. Skalski, E. W. Lusty and M. A. Simmons. 1985. "Avoidance of a Water-Soluble Fraction of a Coal Liquid by Fathead Minnow (Pimephales promelas)." Trans. Am. Fish. Soc. $114: 754-760$.

Dauble, D. D., D. H. Carlfle and R. W. Hanf, Jr. 1986. "Bioaccumulation of Fossil Fuel Components During Single-Compound and Complex-Mixture Exposures of Daphnia magna." Quil. Environ. Contam. Toxicol. 37:125-132.

Garland, T. R., D. A. Cataldo, X. M. McFadden and R. E. Wildung. 1986. "Factors Affecting Absorption, Transport, and Form of Plutonium in Plants." In Proceedings of Sixth Workshop on Environmental Research for Actinide Elements, ed. J. Pinder. National Technical Information Service, Springfield, Virginia (in press). 
Poston, T. M., and D. C. Klopfer. 1986. A Literature Review of the Concentration Ratios of Selected Radionuclides in Freshwater and Marine Fish. PNL-5484, Pacific Northwest Lahoratory, Richland, Washington.

Thomas, J. M., L. L. Cadwell, D. A. Cataldo and T. R. Tarland. 1986. "Distribution of Orally Administered and Chronically Fed Tc-95m in Japanese Quail Tissues and Eggs." In Technetium Behavior in the Environment, eds. . . Desmet and C. Myttenaere, pp. 349-357. Elsevier Applied Science Publishers, London.

Wildung, R. E., D. A. Cataldo and T. R. Garland, 1986. "VoTatilization of Iodine from Soils and Plants." In Speciation of Fission and Activation Products in the Environment, eds. R. A. Bulman and J. R. Cooper, pp. 243-249. Elsevier Applied Science Publisters, London.

Wildung, R. E., T. R. Garland, K. M. McFadden and C. E. Cowan. 1986. "Technetium Sorption in Surface SoiTs." In Technetium Behavior in the Environment, eds. G. Desmet and C. Myttenaere, pp. 115-129. Elsevier Applied Science Publishers, London.

Subsurface Transport

Ainsworth, C. C., J. M. Zachara and R. L. Schmidt. 1986. "Quinoline Sorption on Na-Montmorillonite: Contributions of the Protonated and Neutral Species." Clays Clay Miner. (in press).

Simmons, C. S. 1986. "A Generalization of One-Dimensional SoTute Transport: A Stochastic-Convective Flow Conceptualization." In Proceedings of the Sixth Annual AGU Front Range Branch Hydrology Days, eds. H. J. Morel-Seytoux and J. W. Warner, pp. 131-151. Colorado State University, Fort Collins, Colorado.

Streile, G. P., and C. S. Simmons. 1986. Subsurface Flow and Transport of Organic Chemicals: An Assessment of Current Modeling Capability and Priority Directions for Future Research (1987-1995). PNL-6043, Pacific Northwest Laboratory, Richland, Washington.

Westall, J.C. 1986. "Chemical and Electrostatic Models for Reactions at the 0xide Solution Interface." In Geochemical Processes at Mineral Surfaces, eds. J. A. Davis and $\mathrm{X}$. Hayes. American Chemical Society Symposium Series (in press).

Zachara, J. M. 1985. Design of Field Scale Experiments on Subsurface Transport of Organic chemicals. DOE/LR-0230, IJ.S. Department of Energy, office of Energy Research, Washington, D..

Zachara, J. M., C. C. Ainsworth, C. F. Cowan and B. L. Thomas. 1986. "Sorption of Binary Mixtures of Nitrogen Heterocyclic Compounds on Subsurface Materials." Environ. Sci. Technol. (in press).

Zachara, J. M., and B. I.. Thomas. 1985. "Competitive Adsorution of Aromatic Nitrogen Bases on Subsurface Materials." In Health and Environmental Research on Complex Organic Mixtures, eds. R. H. Gray, E. K. Chess, P. J.Mellinger, R. G. Riley and D. L. Springer, 24th Hanford Life Sciences Symposium, October 21-24, 1985, Richland, Wastington. National Technical Information Service, Springfield, Virginia (in press).

Zachara, J. M., C. C. Ainsworth, L. J. Felice and C. T. Resch. 1986. "Quinoline Behavior in Subsurface Materials: Role of $\mathrm{pH}$ and Sorption of the Organic Cation." Environ. Sci. Technol-20:620-627.

Marine Sciences

Elston, R. A., 1. Harrell and M. T. Wilkinson. 1986. "Isolation and In Vitro characteristics of Chinook Salmon (jncorhynchus tshawytscha) Rosette Agent." Aquaculture 56:1-26.

Feely, R. A., G. J. Massoth, F. T. Baker, J. F. Genaron, A. J. Paulsen and F.. A. Crecelius. 1986. "Seasonal and Vertical Variations in the Elemental Composition of Suspended and Settling Particulate Matter in Puget Sound, Washington." Estuarine Coastal Shelf Sci, 22:215-230.

Lavelle, J. W., (2. J. Massoth and E. A. Crecelius. 1986. "Accumulation Rates of Recent Sediments in Puget Sound, Washington." Marine Geology 72:59-70.

Roesijadi, C. 1986. "Mercury-3inding Proteins from the Marine Mussel, Mytilus edulis." Environ. Health Perspect. 6S:45 48 . 
Roesijadi, G., J. S. Young, E. A. Crecelius and L. E. Thomas. 1985. "Distribution of Trace Metals in the Hydrothermal Vent Clam, Calyptogena magnifica." Biol. Soc. Wash. Bu11. 6:311-324.

Theoretical (Quantitative) Ecology

Eberhardt, L. L. 1985. "Assessing the Dynamics of Wild Populations." J.Wildl. Manage. 49:997-1012.

Fberhardt, I.. E. 1986. Brood Ecology of Canada Geese in Southcentral Washington. Ph.D. Dissertation, Oregon State University, Corvalits, Oregon.

Eberhardt, L. E., I. J. Ball and R. G. Anthony, 1986. "Method for Live-Capturing Adult Canada Geese on Their Nests." Research Information Bulletin No. 86-33, U.S. Fish and Wildlife Service.

Eberhardt, L. L. 1986. "Population Projections from Simple Models." J. Appl. Ecol. (in press).

Eberhardt, L. L., R. R. Knight and B. M. Blanchard. 1986. "Monitoring Grizzly Bear Population Trends." J. Wildl. Manage. $50(4): 613-618$.
Eberhardt, L. I.., and M. A. Simmons. 1986. "Calibrating Indices of Population Abundance Using Double Sampling." J. Wildl. Manage. (in press).

Knight, R. R., and L. L. Fberhardt. 1985. "Population Dynamics of Yellowstone Grizzly Bears." Ecology 66:323-334.

Knight, R. R., B. M. Blanchard and L. L. Eberhardt. 1986. "Population Sinks and Mortality Patterns for Yellowstone Grizzlies." J. Wildl. Manage. (in press). Knight, R. R., and L. L. Eberhardt. 1986. "Prospects for Yellowstone Grizzlies." In Proceedings of the 7 th International Conference for Bear Research and Management (in press).

Ska15ki, J. R. 1985. Use of Capture Data to Quantify Change and Test for Effects on the Abundance of Wild Populations. Ph.D. Dissertation, Cornell University, Ithaca, New York (L. L. Fberhardt onsite advisor).

Skalski, J. R. 1985. "Construction of Cost Functions for Tag-Recapture Research." Wildl. Soc. Bull. 13:273-283. 


\section{PRESENTATIONS}

\section{Arid Land Sciences}

Cushing, C. E. 1986. "Cold Desert Stream Ecology: New Insights or Just Another Point on the Graph." Presented at the Plenary Meeting of the North American Benthological Society, May 21, 1986, Lawrence, Kansas.

Fitzner, R. E. 1986. "Birds as Indicators of Industrial Pollutants." Presented at the Northwest Scientific Association Symposium, March 26, 1986, Cheney, Washington.

Link, S. 0. 1986. "Whole-plant Gas Exchange Dynamics of Artemisia tridentata, Agropyron spicatum, and Agropyron desertorum." Presented at a Seminar sponsored by the Department of Botony, Washington State University, April 14, 1986, Pullman, washington.

Link, S. 0., M. M. Caldwell and J. H. Richards. 1986. "Seasonal Whole-Plant Gas Exchange Dynamics of Artemisia tridentata, Agropyron spicatum and Agropyron desertorum." Presented at the Ecological Society of America Meeting, August 10-16, 1986, Syracuse, New York.

Petron, S. E. 1986. "The Chemical Restraint of Wild and Feral Animals." Presented to the Yakima County Humane Society, March 25, 1986, Yakima, Washington.

Rogers, L. F., and L. L.. Cadwell. 1986. "Insects and Chemical Pollutants." Presented at the Northwest Scientific Association Symposium, March 26, 1986, Cheney, washington.

Biogeochemical Phenomena in Indirect Exposure Patnways

Bean, R. M., D. D. Dauble, B. L. Thomas, R. W. Hanf and E. K. Chess. 1985. "Factors Affecting Bioabsorption, Metabolism, and Storage of Organic Compounds by Aquatic Biota." Presented at the 24th Hanford Life Sciences Symposium, October 22-24, 1985, Richland, Washington.

Cataldo, D. A. 1985. "Speciation of Toxic Trace Flements in Plants and Bioavailability to Animals." Presented at the Anerican Society of Agronomy Annual Meeting, December $1-6,1985$, Chicago, Illinois.
Cataldo, D. A., and R. M. Bean. 1986. "Uptake and Fate of Phenol, Aniline and Quinoline in Terrestrial Plants." Presented at the 24th Hanford Life Sciences Symposium, October 20-24, 1985, Richland, Washington.

Cataldo, D. A., R. M. Bean and R. J. Fellows. 1986. "Uptake and Fate of Xemobiotics in Plants." Presented at the 24th Hanford Life Sciences Symposium, October 20-24, 1985, Richland, Washington.

Cataldo, D. A., and T. R. Garland. 1986. "Chemical Fate and Metabolic Changes Induced by $T c$ in Soybean Plants: Involvement with Sulfur-Based Processes." Presented at the Behavior of Technetium in Terrestrial and Aquatic Environs: Workshop on Research Status and Needs, May 5, 1986, Seattie, Washington.

Dauble, D. D., R. M. Bean, L. R. Curtis and R. W. Hanf. 1986. "Disposition and Clearance of Dietary 14-C Quinoline by Rainbow Trout (Salmo gairdneri)." Presented at the 16th Annual American Fisheries Society Annual Meeting, September 14-18, 1986, Providence, Rhode Is land.

\section{Subsurface Iransport}

Fredrickson, J. K., and R. J. Hicks. 1986. "Chemolithotroph Act $\uparrow$ vity and Aerobic Mineralization Potential in Deep Subsurface Environments." Presented at the 2nd Investigators' Meeting - DOE/SRL Subsurface Microbiology Program, Septenber 22-23, 1986, Washington, D.C.

Garland, T. R., K. M. MCFadden and R. E. wildung. 1986. "Pore Water Chemistry of Subsurface Core Segments from Savannah River Laboratory, South Carolina." Presented at the 2nd Investigators' Meeting - DOE/SRL Subsurface Microbiology Program, September 2223, 1986, Washington, D.C.

Simmons, C. S. 1986. "Using Concepts of Stochastic-Convective Flow to Model Solute Transport." Presented at the Wordon Research Conferences Modeling Flow in Permeable Media, July 30, 1986, Andover, llew Hampshire. 
Zachara, J. M., C. C. Ainsworth and B. L. Thomas. 1985. "Sorption of Binary Mixtures of N-Heteracycles on Subsurface Materials." Presented at the 24th Hanford Life Sciences Symposium, October 20-24, 1985, Richland, Washington.

Marine Sciences

Dungan, C. F., and R. A. Eiston. 1986. "Destruction of Bivalve Mollusc Hinge Ligament by Cytophaga-like Bacteria: Association with Mortality in Hatchery-Reared Juvenile Pacific Oysters, Crassostrea gigas." Presented at the 78th Annual National Shellfisheries Association Meeting, June 23, 1986 , Seattle, washington.

Elston, R. A. 1986. "Bonamia ostrea Disease of the European Flat Oyster (Ostrea edulis) in North America: Occurrence, Environmental Effects and Host Range." Presented at the 78 th Annual National Shellfisheries Association Meeting, June 23, 1986, Seattle, Washington.

Elston, R. A. 1986. "Evaluating Disease Risks in Shellfish Movements--A Technical Perspective." Presented at the World Mariculture Society Meeting, Janury 22, 1986 , Reno, Nevada.

Elston, R. A. 1986. "Molluscan Health Management in Aquaculture." Presented at the Mol luscan Diseases Workshop, September 12, 1986, Vigo, Spain.

Elston, R. A., and M. L. Kent. 1986. "A Parasitic Amoeba Causing Significant Mortatities in Cultured Geoduck (Panope generosa) Larvae." Presented at the World Mariculture Society Meeting, January 22, 1986, Reno, Nevada.

Theoretical (Quantitative) Ecology

Bromenshenk, J. J., J. L. Gudat is, J. M. Thomas, M. A. Simmons, and J. C. Simpson. 1986. "Useful Methods for Monjtoring with Bees: Minihives and Kriging." Presented at the 18th Annual Air Pollution Warkshop, April 14-18, 1986, Chicago, Illionis.
Eberhardt, L. F. 1986, "Movements and Behavioral Activities of Great Basin Canada Goose Broods." Presented at the Northwest Section Wildife Society Meeting, March 20, 1986, Coos Bay, Oregon.

Knight, R. R., and L. L. Eberhardt. 1986. "Prospects for Yellowstone Grizzlies." Presented at the 7th International Association for Bear Research and Management Conference, February 2, 1986, Williamsburg, Virginia.

Skalski, J, R. 1986. "Statistical Sampling Strategies." Presented at a Technology Transfer Seminar on Hazardous Waste Manage. ment: Emerging Technologies, July 29 and 30 , 1986, Seattie, Washington.

Skalski, J. R. 1986. "Use of Paired-Plot Designs in Mark-Recapture Investigations." Presented at the Joint National Meetings of the American Statistical Association and Biometrics Society, August 18-21, 1986, Chicago, Illinois.

Thomas, J. M. 1986. "Large- and Small-Scale Studies of Variability at the Hanford Site." Presented at the DOE Intercontractor Meeting, March 11, 1986, Mercury, Nevada.

\section{Exploratory Research}

Cowan, C. E. and E. A. Jenne. 1985. Methodology for Determining the Bioavailable Species of a Metal." Presented at the Society of Environmental Toxicology and Chemistry Sixth Annual Meeting, November 10-13, 1985, St. Louis, Missouri.

Cowan, C. E. 1986. "Metal Speciation: An Approach to Predicting Toxicity of Metals in Different Waters." Presented at the 16th Annual American Fisheries Society Meeting, September 14-18, 1986, Providence, Rhode Is iand. 


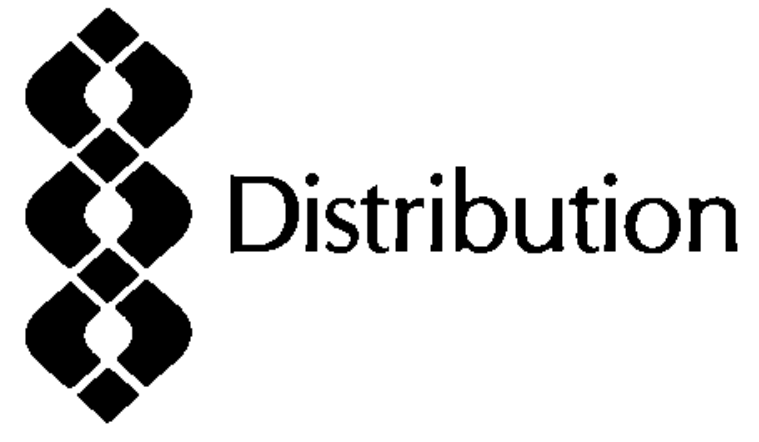




\section{DISTRJBUTION}

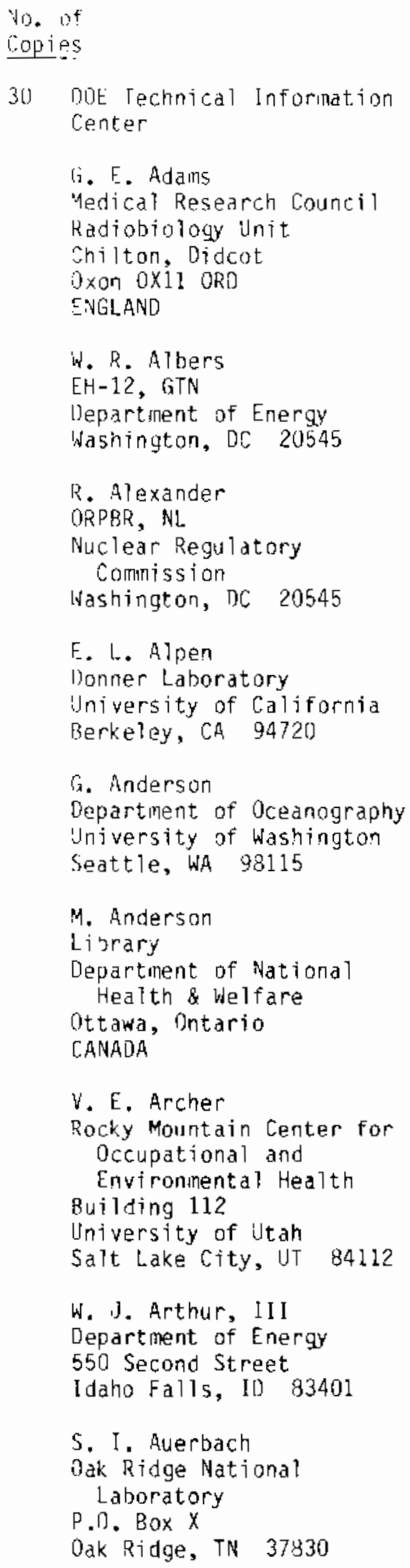

No. of

Copies

D. C. Auman

Institut fur Physikalische Chemie

Ser Iniversital Bonn

Abt. Nuklearchemie

Wegelerstrabe 12

5300 Bonn 1

FEUERAL REPUBLIC OF

GERMANY

J. A. Auxier

IT/ Radiological Services Laboratory

Box 549

Dak Ridge, TN 37831

F. Badgley

1374941 st Street, N.E.

Seattle, WA 98125

D. L. Balkwill

Biological Sciences

313 Conradi Building

Tallahassee, FL 32306

R. M. Baltzo

Radiological Safety

Division

University of washington

Seattle, WA 98105

R. W. Barber

EH-131, GTN

Department of Energy

washington, DC 20545

A. D. Barker

Battelle, Columbus

Laboratories

$505 \mathrm{King}$ Averue

Columbus, OH 43201

J. R. Barker

Office of Environmental

Audit and Compliance

Departinent of Energy

Washington, DC 20545

N. F, Barr

ER-73, GTN

Departinent of Energy

Washington, DC 20545

J. K. Basson

Raad Op Atomic

Atoornkrag Energy Board

Privaatsk $\times 256$

Pretoria 0001

REPIJRLIC OF SOIJTH AFRICA
No. of

Cojies
J. F. Baublitz Department of Energy

office of Nuclear Energy $N E-20$

Gerinantown, MD 20545

0. 3aungartner

Environimental Protection Agency

NERC

$2005.4 .35 t h$

Corvallis, oR 97330

T. Beastey

Argonne Nationa?

Laboratory

9700 South Cass Avenue

Argonne, IL 60439

J. R. Beall

ER-72, GTV

Departiment of Energy

Washington, DC 20545

E. W. Bean

Rocky Flats Area Office

A Thuquerque Dperations Office

Department of Energy

P.0. $30 \times 928$

Golden, co 80401

A. M. Beau, Librarian Conmissariat a l'Energie At ormi que

Departement de Pratection Sanitaire

BP 6, F-92260

Fonteney-Aux-Roses

FRANCE

G. Bengtsson

Statens

Stralskyddsinstitut

Box 60204

S-10401 Stockholin

SWEDEN

M. H. Bhattacharyya

BIM Div., B1dy. 202

Argonne National

Laboratory

9700 South Cass Avenue

Aryonne, IL 60439 
No. of

Copies

\author{
A. Bianco \\ C.N.E.N. \\ Laboratorio Fisica \\ Sanitaria \\ V. Mazzini \\ 40138 Bologna \\ ITALY \\ W. R. Bibb \\ Energy Prograns and \\ Support Division \\ Departinent of Energy \\ P.0. Box B \\ Oak Ridge, TN 38731 \\ J. H. Birely \\ Los Alamos National \\ Laboratory \\ P.0. Box 1663 \\ Los Alamos, NM 87545
}

R. P. Blaunstein

EH-132, GTN

llepartment of Energy

Washington, DC 20545

S. Bolton

U.5. Department of Commerce

National Oceanic \&

Atmospheric

Administration

HG Hoover Building,

$\mathrm{Rm}$. 5222

LAX 1

Wasnington, DC 20230

C. H. Borgstrom

F.H-151, FORS

Department of Energy

Wastington, DC 20585

L. C. Brazley, Jr.

NE-22, GTN

Departinent of Energy

Washington, DC 20545

A. Brink

SASOL-One Limited

P.O. Box I

Sasolburg 9570

REPUBLIC OF SOUTH AFRICA

W. Broecker

Lamont Geological

Observatory

Columbia university

Palisades, NY 10964 ito. of

Copies

G. W. Brown, Jr.

School of Fisheries

University of Washington

Seattle, WA 98195

P. Buhl

FE-34, GTN

Department of Energy

Washington, DC 20545

0. Buhler

Department of Agricultural

Chemistry

Oregon State University

Corvallis, OR 97331

R. J. Bull

Associate Professor of

Pharmacology/Toxicology

College of Pharinacy

Pullman, WA 99164-6510

D. Bunch

Departinent of Energy

NE-40, GTN

Washington, DC 20545

G. Burley

Enviromental Protection Agency

Washington, DC 20460

W. W. Burr

Oak Rídge Associated Universities

P.0. Box E

Oak Ridge, TN 37830

L. Bustad

College of Veterinary

Medicine

Washington State

University

Pullman, WA 99163

J. T. Callahan

Ecosystems Studies Program

National Science

Foundation

Washington, DC 20545

Cao Shu-yuan

Laboratory of Radiation Medicine

North China Institute of Radiation Protection

Taiyuan, Shanxi

THE PEOPLE'S REPUBL IC OF CHINA
No. of

Copies

M. Carpentier

Comission of the E.C.

200 Rue de la Loi

$\mathrm{J}-70 \mathrm{G} / 16$

1049 , Brusse1s

BELGIUM

M. A. Carregado

Gerencia de Proteccion

Radiologica y Seguridad

Comiston Nacional de

Energia Atomica

Casilla de Carreo 40

1802 Aeropuerto Int.

Ezeiza

ARGENT INA

R. Catlin

Electric Power Research Institute

3412 Hillview Avenue

Palo Alto, CA 94304

CEC

DG $\times 11$ Library

SDM8R1

200 Rue de la Loi

B-1049, Brussels

BELGIUM

Chairman, Biology

Department

Central Washington

University

Ellensburg, WA 98926

D. Chapman

College of Fisheries

University of Washington

Seattle, WA 98115

Chen Xing-an

Laboratory of Industrial Hygiene

Ministry of Public Health

2 Xinkang Street

Deshangmanwai, Beijing

THE PEOPLE'S REPUBLIC OF CHINA

G. Chesters

Water Resources Center University of Wisconsin Madison, WI 53706

Chief

Game Management Division

Department of Game

600 North Capitol Way

O1ympia, WA 98501 
No. of

Copies

L. E. Elliott

Departiment of Agromomy and Soils

Washington State

University

Pullman, WA 99164-6510

R. Engelmann

Department of Energy

Office of Environment, Safety and Health

$\mathrm{EH}-30$

cermantown, MD 20545

Environmental Measurements Laboratory

Department of Energy

375 Hudson Street

New York, NY 10014

R. Eppley

Scripps Institute of Oceanography

Lajolla, CA 92307

B. M. Erickson

DOE - Schenectady Naval

Reactors Office

P.0. Box 1069

Schenectady, NY 12301

Estaco Agronomica Nacional

Bibliotecd

2780 0eiras

PORTUGAL

S. J. Farmer

Battelle - Seattle

4000 NE 4lst Street

Seattle, WA 98105

S. L. Fawcett

Battelle Memorial

Institute

$505 \mathrm{King}$ Avenue

Columbus, $\mathrm{OH} 43201$

L. Feinendegen

Institut für Medezin

Kernsforschungs sanlage Jijlich

Postfach 1913

D-5170 Jij $7 i c h$

FEDERAL REPUBLIC OF GERMANY

W. 0. Forster

Office of Energy Research

Department of Energy

Washingt on, DC 20545
No. of

Copies

R. M. Fry

Office of the Supervising Scientist for the

Alligator Rivers Region

P. 0. Box 387

Bondi Junction NSW 2022

AUSTRALIA

A. Gahler

Environment al Protection Agency

Region $X$ Laboratory

P.0. Box 549

Manchester, WA 98353

c. George

Department of Energy

Office of Defense Programs

$\mathrm{UP}-12$

Germantown, MD 20545

G. B. Gerber

Radiobiology Department

Comnission of European

Communities

Rue de la Loi

Brussels

BELGIUYY

H. C. Ghiorse

Microbiology Department

415 Stocking Hall

Cornell University

Ithaca, NY 14853

H. Giles

Department of Energy

Strategic Petroleum

Reserve

FE 531, FORSTL

1000 Independence Ave., SW

Washington, DC 20585

E. Goldberg

Scripps Institute of Oceanography

Lajolla, CA 92307

M. Goldinan

Laboratory for Energy-

Related Health Research

University of Califarnia

Davis, CA 95616

G. Goldstein

ER-74 GTN

Departinent of Energy

Washington, DC 20545
No. of

Copies

A. R. Gopal-Ayengar

73-Mysore Colony

Mahul Road, Chembur

Bombay 400074

INDIA

A. Grauby

Service d'Etudes at

de Recherches sur

1 'Environment

Commissariat L'Energie

Atomique

Caderache, B.P. No. 1

BAT 15313115

Saint Paul Lez. Durance

FRANCE

G. H. Gronhovd

Grand Forks Energy

Research Center

Department of Energy

Box 8213, University

Station

Grand Forks, ND 58202

D. H. Hamilton, Jr.

ER-75, GTN

Department of Energy

Washington, DC 20545

W. Hansen

Los Al amos National

Laboratory

P.0. Box 1663

MS: $K-491$

Los Alamos, NM 87545

D. W. Hayne

Department of Experimental Statistics

North Carolina State University

Box 5457

Raleigh, NC 27607

J. W. Healy

Los Alamos National

Laboratory

P.0. Box 1663

Los Alamos, NM 87545

A. P. Hull

Building 535-A

Safety and Environmental

Protection Division

Brookhaven National

Laboratory

Upton, Long Island, NY 11973 
No. of

Copies

\author{
F. Hutchinson \\ Department of Molecular \\ Biophysics and \\ Biochenistry \\ Yale University \\ P.0. Box 6666 \\ 260 Whitney Avenue \\ New Haven, CT 065!1 \\ International Atomic \\ Energy Agency \\ Documents Library \\ Attn: Mrs. Javor \\ Vienna 1, Kaerntnerring 11 \\ AUSTRIA \\ D. Irwin \\ Librarian \\ Supervising Scientist for \\ the Alligator Rivers \\ Region \\ P.0. Box 387 \\ Bondi Junction 2022 \\ AUSTRALIA \\ H. Istikawa \\ Nuclear Safety Research \\ Association \\ P.0. Box 1307 \\ Falls Church, VA 22041 \\ K. L. Jackson \\ Radiological Sciences \\ D-2l8 Health Sciences \\ University of Washington \\ Seattle, Wa 98195 \\ R. M. Jefferson \\ Sandia Laboratories \\ P.0. Box 5800 \\ A)buquerque, NM 87187 \\ K. E. Lennart Johansson \\ National Defense Research \\ Inst itute \\ FOA 451 \\ S-901-82, Umea \\ SWEDEN
}

A. Johnson

San Diego State University

San Diego, CA 92.128

L. J. Johnson

EG\& Idaho

P.0. Box 1625

Idaho Falls, ID 83415
No. of

Copies

R. Johnson

EPA, Office of Radiation Proyrams (ANR-460C)

401 M Street, SW

Washington, DC 20460

G. Y. Jordy

ER-30, GTN

Departinent of Energy

Washington, OC 20545

V. A. Kamath

Scientific Information officer

Library \& Inforination Service

Atonic Energy Establishment Trambay

Apollo Pier Road

Bombay-1

INDIA

R. F. Kendall

Bartlesville Energy Research Center

Department of Energy

P.0. Box 1398

Bartlesville, 0x 74005

T. Kimball

National Wildlife

Federation

1512 Sixteenth Street NW

Washington, DC 20036

Dr. rer. nat. Hans-Jodchiı $\mathrm{Kli}$ in sch

BASF Axtiengesel lschaft

Abteilung Toxikolagie

D-6700 Ludwigshafen

FEDERAL REPUBLIC OF GERMANY

\section{Kosorok}

Departinent of Statistics Brigham Young University

Provo, UT 84602

G. H. Kraft

c/o GSI Postbox 110541

Planck Str. D6130

Darinstadt

FEDERAL REPUBLIC UF GERMANY

R. T. Kratzke

EH-131, GTN

Departinent of Energy

Germantown, MD 20545
No. of

copies

D. Krenz

Departinent of Energy

Albuquerque operations Office

P.). Box 5400

Albuqueriue, NM 87115

T. Kuinatori

National Institute of Radiological Sciences

9-1, 4-Chome, Anagawa

Chiba-shi, Chiba 260

JAPAN

R. T. Lackey

Environinental Protection Agency

201) S4 35tin Street

Corvallis, OR 97333

R. P. Larsen

Argonne National

Laboratory

9700 South Cass Avenue

Argonne, IL 60439

W. Lauder

Office of Health and

Environmental Research

Office of Energy Research

Departiment of Energy

Gerinantown, MID 20545

Li Derping

Professor and Director of North China Institute of Radiation Protection, NMI

Tai-yyan, Shan-xi

THE PEOPLE'S REPIJBLIC OF CHINA

Librarian

Atomic Energy of Canda Ltr.

Whiteshell Nuclear Research Establishment Pinawa, Manitoba rOE ILO CANADA

Librarian

Atomic Energy Research

Establishinent

Building 465

Harwell, Didcot

Gxon OXI1 ORO

ENGLAND 
*o. of

Copies

Librarian
Australian Atomic Energy
Comission
Riverina Laboratory
P.O. Box 226
Deniliquin, New South
Wales
AUSTRALIA 2710
Librarian
Battelle Memorial
Institute
Columbus Laboratories
505 King Avenue
Columbus, OH 43201
Librarian
Brookhaven Natianal
Laboratory
Research Library,
Reference
Upton, Long Island,
Ny I1973

Librarian

Centre d'Etudes

Nucléaires de Saclay

P.0. Box 2, Sactay

Fig-sur-Yvette (S\&D)

FRANCE

Librarian

Colorado State University

Serials Section

Ft. Collins, Co 80521

Librarian

Commonwealth Scientific

and Industrial Research Organization

314 Albert Street

P.0. Box 89

East Melbourne, Victoria

AUSTRALIA

Librarian

CSIRO

Rangelands Research Centre

Private Mail Bag, P.0.,

DENILIOQUIN, N.S.H. 2710

AUSTRALIA

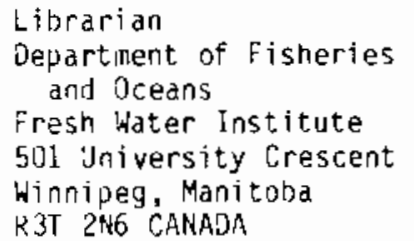

No. of

Copies

Librarian

Departinent of Fisheries and 0ceans

Pacific Biological Station

P.0. Drawer 100

Nanaimo, British Columbia

VGR $5 K 6$ CANADA

Librarian

ENEA (OECD) Health and Safety of ice

38 , Blvd. Suchet

Paris

FRANCE

Librarian

Environinental Research Laboratory

Environmental Protection Agency, ORD

Gulf Breeze, FL 32561

Librarian

Environmental Research Laboratory

Environmental Protection Agency, ORD

Narragansett, RI 02882

Librarian

Environmental Research Laboratory-Duluth

Dr. N. A. Jaworski

6201 Congdon Bivd.

DuTuth, MN 55804

Librarian

Fisheries/Oceanography

University of Washington

Seattle, WA 98115

Librarian

$\mathrm{HCS} / \mathrm{EHE}$

World Health Organization

CH-12l1 Geneva 27

SWITZERLAND

Librarian

Health Sciences Library, SB-55

University of Washington

Seattle, WA 98195

Librarian

Kernf orschungzentrum

Karlsruhe

Institut für

Strahlenbiologie

D-75 Karlsruhe 1

Postfach 3640

FEDERAL REPUBLIC OF GERMANY
No. of

Copies

\section{Librarian}

Los Alamos National

Laboratory

P.0. Box 1663

Los Alamos, NN B7545

Librarian

Max-Planck-Institut für Biophysics

Forstkasstrasse

0-6000 Frankfurt/Main

FEDERAL REPUBLIO

OF GERMANY

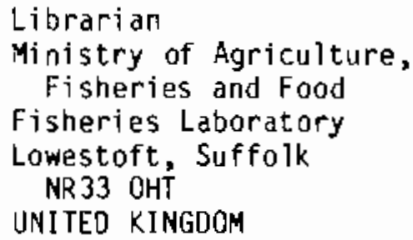

Librarian

Ministry of Agriculture, Fisheries and Food

Fisheries Laboratory

Lowestoft, Suffolk

NR33 OHT

UNITEO KINGDOM

Librarian

Northwest and Alaska

Fisheries Center

National Marine Fisheries Service, NOAA

2725 Montiake Bivd. East

Seattle, WA 98112

Librarian

Robert S. Kerr

Environmental Research Laboratory

Environmental Protection Agency, ORO

Ada, OK 74320

Librarian

Southeast Fisheries Center

National Marine Fisheries Service, NOAA

75 Virginian Beach Drive

Mi ami, FL 33149

Librarian

Southwest Fisheries Center

National Marine Fisheries Service, NOAA

P.0. Box 271

La Jolla, CA 92038

Librarian

Washingt on State

University

Pullman, WA 99164-6510

Librarian

Serials Section

University of Washington

Seattle, WA 98195 
No. of

Copies

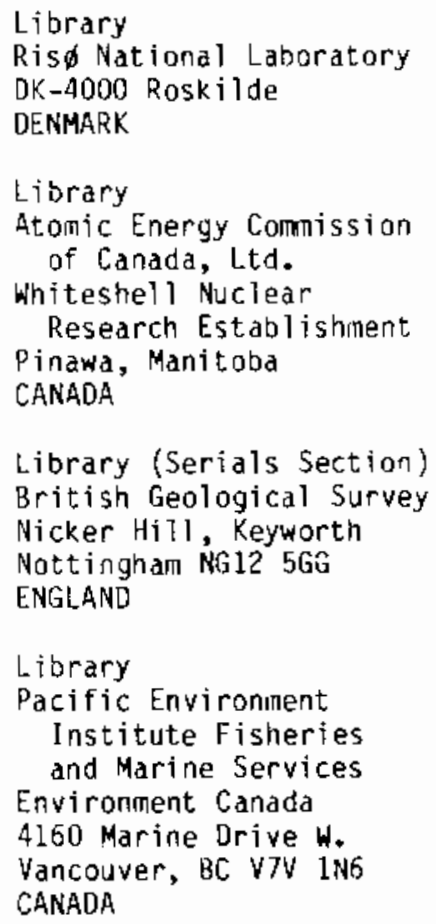

B. Lindell, Director National Institute of Radiation Protection
No. of

Copies

B. Madia

Battelle Colunbus

Laboratory

505 King Avenue

Columbus, $\mathrm{OH} 43201$

J. R. Maher

CR-65, GTN

Department of Energy

Washington, DC 20545

D. Malins

National Marine Fisheries

Iniversity of Washington

Seattle, WA 98115

C. R. Mandelbaum

$E R-32$, GTN

Departinent of Energy

washington, DC 20545

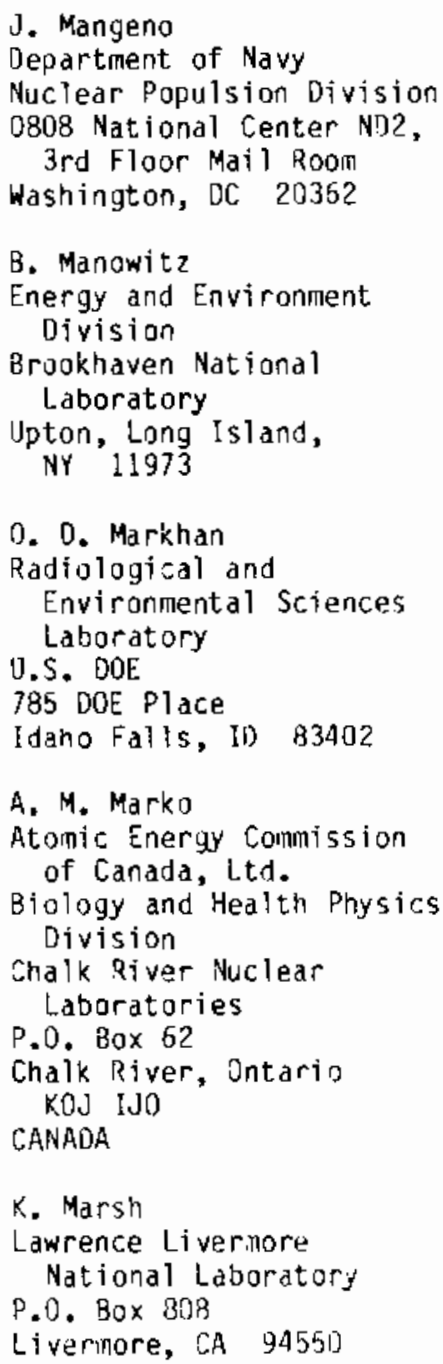

No. of

Copies

\section{R. A. Mayes}

Department of Energy Chicago Operations Office 9800 S. Cass Avenue Argonne, IL 60439

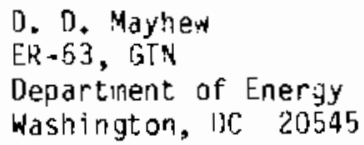

H. M. MCCammon

$E R-75$, GTN

Departinent of Energy

Washington, DC 20545

R. 0. Mcclellan

Inhalation Toxicology Research Institute

Lovelace Foundation for Medical Education \& Research

P.0. Box 5890

Albuquerque, NN 87115

T. F. McCraw

EH-132, GTN

Departinent of Energy

Hashington, OC 20545

C. B. Meinhold

Safety and Environmental Protection Division

Brookhaven National Laboratory

Upton, Long Island, NY 11973

M. L. Mendelsonn

Biomedical and

Environmental Research Program

Lawrence Liverinore National Laboratory, L-523

University of California P.D. Box 809

Livermore, CA 94550

H. Metivier Centre d'Etudes de Bruyeres-le-Chatel Laboratoire de Toxicologic Experimentale

B.P. No. 561

92542 Montrouge Cedsx FRANCE 
No. of

Copies

M. L. Minthorn, Jr. ER-7?, GTN

Departinent of Energy

Washingt on, OC 20545

F. Molz

Department of Civil

Engineering

238 Harbert Engineering Center

Auburn University

Auburn, AL 36849

D. R. Monti

ER-14, GTN

Department of Energy

washington, DC 20545

J. J. Morgan

Calffornia Institute of Technology

Mail Code 138-79

Pasadena, CA 91125

W. E. Mott

EH-12, GTN

Department of Energy

Washington, $D C 20545$

1. Murarka

EPRI

$3412 \mathrm{Hi} l 1$ view Avenue

P.D. Box 10412

Palo Alto, CA 94303

Prof. C. Myttenaere

Laboratoire de Physiologie Vegetale (FYVE)

Place Croix du Sud, 4 B-1348 Lowvain-La-Netuve BELGIUM

R. E. Nakatani

Assistant Director

Fisheries Research Institute

260 Fisheries Center

iniversity of Washington

Seattle, WA 98115

R. Nathan

Battelle Project

Management Division

505 King Avenue

Columbus, OH 43201

S. M. Nealey

Battelle - Seattle

$4000 \mathrm{NE} 41 \mathrm{st}$ Street

Seattle, WA 98105
No, of

Copies

N. Nelson

Environmental Protection Agency

Washington, DC 20460

J. C. Nénot

Departenent de Protection

Centre d' Etudes

Nucleaires

B.P. No. 6

F-92260 Fontenay-Aux-Roses

FRANCE

W. R. Ney

Director

National Council on

Radiation Protection and Measurement

7910 Woodmont Avenue

Suite 1016

Washington, DC 20014

C. R. Nichols

Department of Energy

Idaho Falls operations Office

785 DOE Place

Idaho Falls, ID 83401

Nuclear Regulatory Commission

Advisory Committee on Reactor Safeguards

Washington, DC 20555

E. O'Donnel

Nuclear Regulatory Commission

Washington, DC 20545

G. Oertel

Department of Energy

Gerinăntown, MD 20545

D. E. Dlesen

Battelle Menorial

Institute

$505 \mathrm{King}$ Avenue

Columbus, $\mathrm{OH} 53201$

J. P. Oliver

ENEA (OECD) Health and

Safety office

38, Bivd. Suchet

Paris

FRANCE

W. S. Osburn, Jr.

ER-75, GTN

Department of Energy

Washington, DC 20545
No. of

Copies

C. Osterberg
ER-75, GTN
Department of Energy
Washington, DC 20545

N. Pace

Environmental Physiology Lab T-2251

University of California

Berkeley, CA 94720

A. F. Perge

RW-43, FORS

Department of Energy

Washington, DC 20545

S. Peterson

Corvallis EPA

200 S.W. 35th St.

Corvallis, OR 97333

G. Pinder

Princeton University

School of Engineering/

Applied Science

Princeton, NJ 08544

W. Piver

NIEHS

P.0. Box 12233

Research Triangle Park, NC 27709

V. Prodi

Department of Physics

University of Bologna

Via Irmerio 46

I-40126 Bologna

ITALY

R. Rabson

Department of Energy

MS-226, GTN

Washington, DC 20545

D. P. Rall, Director

NIEHS

P.0. Box 12233

Research Triangle Park, NC 27709

J. M. Ramìrez

Allied Corporation

Bendix-Kansas City

Division

P.0. Box 61959

Dept. 144 -

Mail Code 0B-29

Kansas City, MO 64141-6159 
No. of

Copies

w. Reese

DOE - Savannah River

Operations office

P. D. Box A

Aiken, SC 29801

Regional Director

EPA Region Office

1200 6th Avenue

Seattle, WA 98101

D. Reichle

Dak Ridge National

Laboratory

P. D. Box $X$

Oak Ridge, TN 37830

Renzhi Wang

Institute of Radiation Medicine

11 Tá Ping Road

Bejjing

THE PEOPLF'S REPUBLIC OF CHINA

J. 7. Reynolds

Consumer Power Co.

$212 \mathrm{~W}$. Michigan Avenue

jackson, MI 49201

C. R. Richmond

Oak Ridge National

Laboratory

P.0. Box $X$

Oak Ridge, TN 37830

C. Roberts

Nuclear Regulatory

Comrission

ivashington, DC 20555

1. S. Robertson

ER-73, GTN

Department of Énerqy

Washington, DC 20545

P.J.A. Rombout

Inhalation Toxicology Department

National Institute of

Public Health and

Environmental Hygiene

P.0. Box I $3720 \mathrm{BA}$

Bi 1 thoven

THE NETHERLANDS

D. M. Rass

EH-121, GTN

Department of Enerqy

Washington, DC 20545
Vo. of

Copies

M. Rzekiecki

Commissariat à l'Energie At oni que

Centre d'Etudes

Nucléaires de Cadarache

BP No. 13-5t. Paul

Les Durance

FRANCE

L. Sagan

Flectric Power Research Institute

3412. Hillview Avenue

Palo Alto, CA 94304

R. A. Scarano

Nuclear Regulatory

Commission

Mill Licensing Section

Washington, DC 20545

M. Schulman

ER-70, GTN

Departiment of Energy

Washington, DC 20545

R. Scott

Department of Energy

office of Environment,

Safety and Health

Germantown, M0 20545

L. Selini

Vienna International

Center

P.0. Box 500

1400 Vienna

AUSTRIA

G. H. Setlock

Rockwell International

North American Space Operations

Rocky Flats Plant

P.0. Box 464

Golden, C.0 80402

R. Shikiar

Battelle - Seattie

$4000 \mathrm{NE} 41$ st Street

Seattle, WA 98105

D. B. Shipter

Battelle Menorial

Institute

$505 \mathrm{King}$ Avenue

Columbus, $\mathrm{OH} 53201$
No. of

Copies

G. Silini

Vienna International

Center

P. 0 . Box 500

A-l400 Vienna

AUSTRIA

1.) Simmons

Bioaffects Analysis Branch

U.S. Environmental

Protection Agency

401 M. Street S.W.

Washington, DC 20460

W. X. Sinclair

NCRP

7910 Woodmont Avenue

Suite 1016

Bethesda, MD 20814

R. Skogstrom

Chief Librarian

Meteorological Institute

University of Stockholm

Arrhenius Laboratory

$\$ 10691$ Stockholm

SWEDEN

6. 4. Slade

ER-74, GTN

Department of Energy

Washington, DC 20545

D. A. Smith

ER-72, GTN

Department of Energy

Washington, DC 20545

H. Smith

Biology Department

National Radiological

Protection Board

Chilton, Didcot

Oxon 0x11 0RQ

ENGLAND

M. Smith

Savannah River Ecology

Laboratory

Iniversity of Georgia

Savannah River Plant

P.0. Box A

Aiken, SC 29801

G. A. Smithwick

EH-20 FORS

Washington, DC 20585 
:No. of

copies

\author{
J. Snow \\ ER-6, FORS \\ Department of Energy \\ Washington, DC 20585 \\ G. Sposito \\ University of California \\ at Riverside \\ Riverside, CA 93521 \\ J. N. Stannard \\ 17441 Plaza Animado \#132 \\ San Diego, CA 92128 \\ J. W. Stather \\ National Radiological \\ Protection Board \\ Building 383 \\ Harwell, Didcot \\ 0xon 0X11 ORO \\ ENGLAND
}

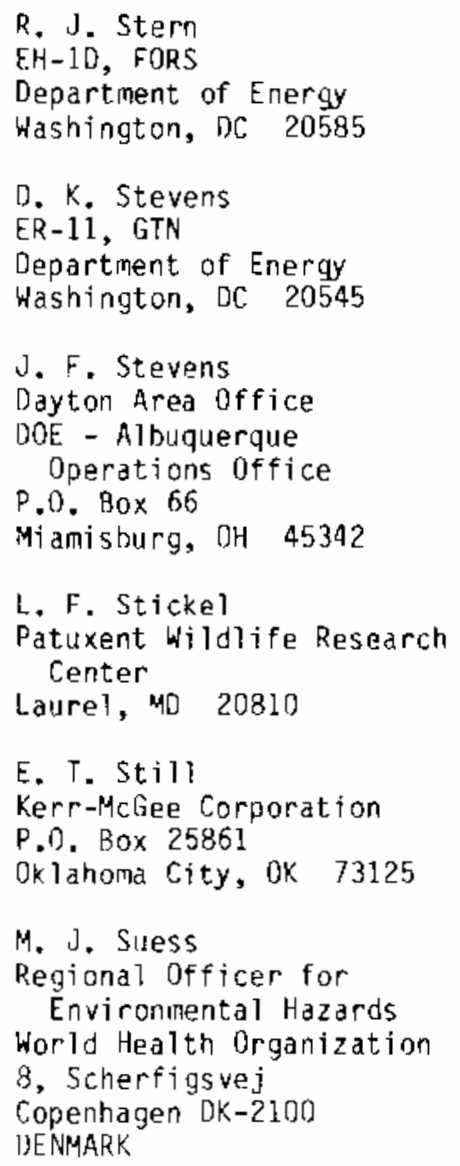

R. J. Stern

E.H-1D, FORS

Department of Energy

Washington, DC 20585

D. $K$. Stevens

ER-11, GTN

Department of Energy

Washington, DC 20545

J. F. Stevens

Dayton Area Office

DOE - Albuquerque

Operations office

P.0. 80x 66

Miamisburg, OH 45342

L. F. Stickel

Patuxent Wildlife Research Center

Laure1, M0 20810

E. T. Still

Kerr-Mcliee Corporation

P.D. Box 25861

Oklahoma City, OK 73125

M. J. Suess

Regional Officer for

Environmental Hazards

World Health Organization

8 , Scherfigsvej

Copenhagen DK-2100

IJENMARK

No. of

Copies

\author{
J. M. Suflita \\ Department of Botany and \\ Microbiology \\ University of Oklahoma \\ Norman, OK 73019 \\ Sun Shi-quan \\ Radiation-Medicine \\ Department \\ North China Institute \\ of Radiation Protection \\ Taiyuan, Shanxi \\ THE PEOPLE'S REPUBLIC \\ DF CHINA \\ F. Swanberg \\ Nuclear Regulatory \\ Commission \\ Nashington, DC 20545

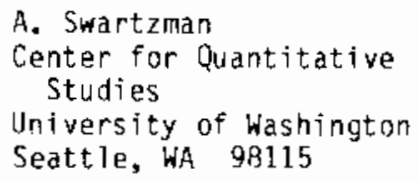

A. Swartzman

Center for Quantitative Studies

University of Washington

Seattle, WA 98115

J. Swinebroad

$\mathrm{EH}-12$, GTN

Department of Energy

Washington, DC 20545

Technical Information
Service

Savannah River Laboratory

Room 773A

E. I. duPont de Nemours $\&$ Company

Aiken, SC 29801

\section{T. Terasima \\ Director-General \\ National Institute of Radiological Sciences \\ Anagawa-4, Chiba-5i 260 JAPAN}

J. W. Thiessen

ER-71, GTN

Department of Energy

Washington, DC 20545

R. G. Thomas

ER-72, GTN

Department of Energy

washington, DC 20545
No. of

Copies

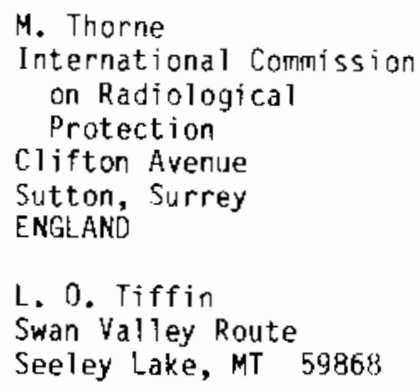

M. Thorne

International Comission on Radiological Protection

Clifton Avenue Sutton, Surrey ENGLAND

L. 0. Tiffin

Swan Valley Route

Seeley Lake, MT 59868

A. W. Trivelpiece

American Association for the Advancement of Science

1515 Massachusetts Ave., NW

washington, DC 20005

United Nations Scientific Committee on the Effects of Atomic Radiation

Vienna International Center

P.0. Box 500

A-1400 Vienna

AUSTRIA

U.S. Department of Energy

Environment, Safety and Health Division

P.0. Box 5400

A)buquerque, NM 87115

E. J. Vallario

$P E-222$, GTN

Department of Energy

Washington, DC 20545

D. Van As

Private Bag X256

Pretoria 0001

Atomic Enerqy Board

REPUBLIC OF SOUTH AFRICA

C. R, Vest

Battelle Memorial

Institute

Washington Operations

2030 M Street, NW

Washington, DC 20036

Vienna International

Center Library

Gifts and Exchange

P.0. Box 100

A-I 400

Vienna

AUSTRIA 
No. of

Copies

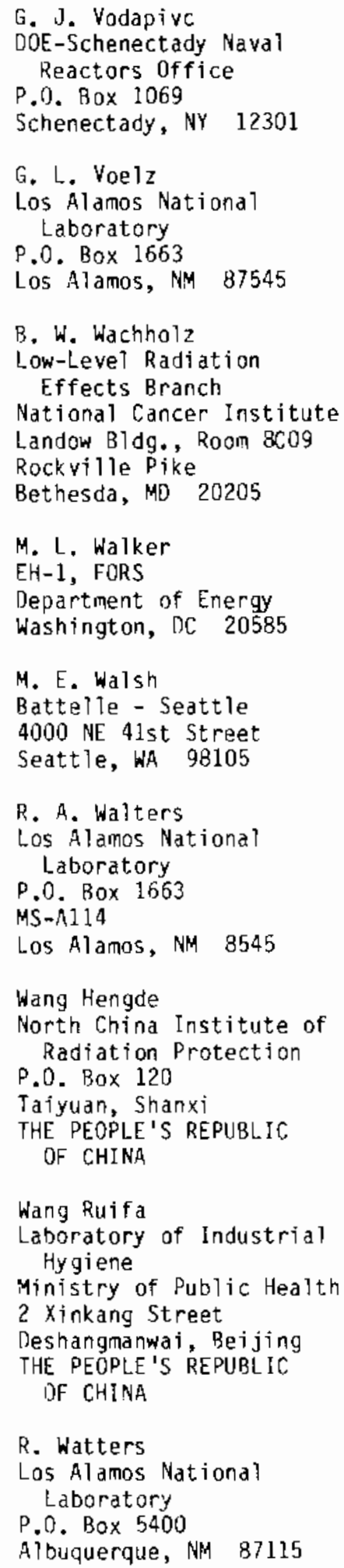

No. of

Copies

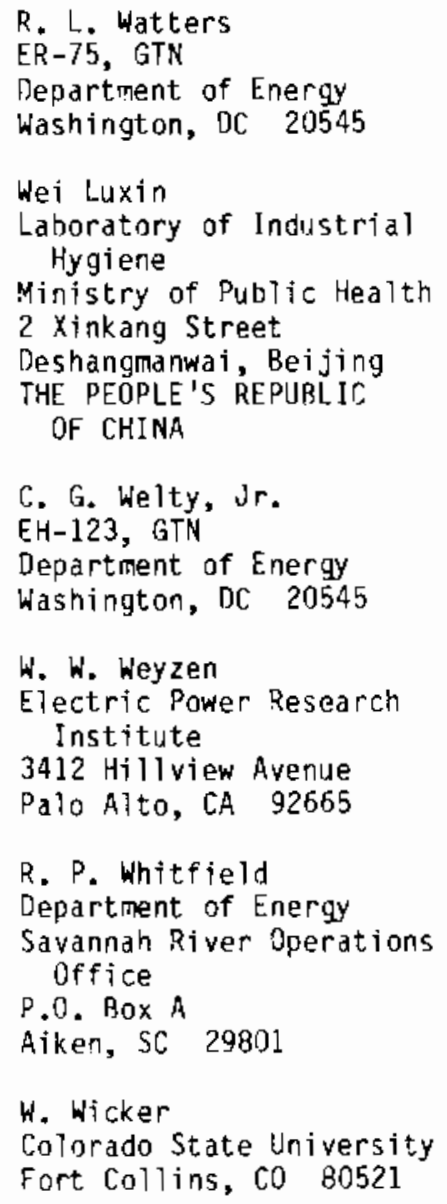

Wei Luxin

Laboratory of Industrial Hygiene

Ministry of Public Health

2 Xinkang Street

Deshangmanwai, Beijing

THE PEOPLE'S REPUBLIC. OF CHINA

C. G. Welty, Jr.

EH-123, GTN

Department of Energy

Washington, DC 20545

\section{W. W. Weyzen \\ Electric Power Research Institute \\ 3412 Hillview Avenue \\ Palo Alto, CA 92665 \\ R. P. Whitfield \\ Department of Energy \\ Savannah River Operations Office \\ P.0. Box A \\ Aiken, SC 29801 \\ W. Wicker \\ Colorado State University \\ Fort Collins, C0 80521}

M. M. Williamson

DOE - Idaho Operations Cominission

550 Second Street

Idaho Falls, ID 83401

D. L. Willis

Department of Genera] Science

Oregon State University

Corvallis, OR 97331

B. C. Winkler

Licensing

Raad Op Atoomkrag

Privaatsk $\times 256$

Pretoria 0001

REPUBLIC OF SOLUTH AFRICA

F. J. Wobber

Department of Energy

ER-75 MS:G-226, GTN

14 Goshan Ct.

Gaithersburg, MD 20879
No. of

Copies

M. T. Wood

Battelle - Seattle

$4000 \mathrm{NE}$ 415t Street

Seattle, WA 98105

R. W. Wood

ER -74 , GTN

Departinent of Energy

washington, IX 20545

Wu De-Chang

Institute of Radiation Medicine

11. Tai Ping Rd.

Beijing

THE PEOPLE'S REPUBLIS OF CHINA

Xiuzhen $\mathrm{Hu}$

North China Institute of Radiation Protection, NMI

Tai-yuan, Shan-xi

THE PEOPLE'S REPIJBLIC DF CHINA

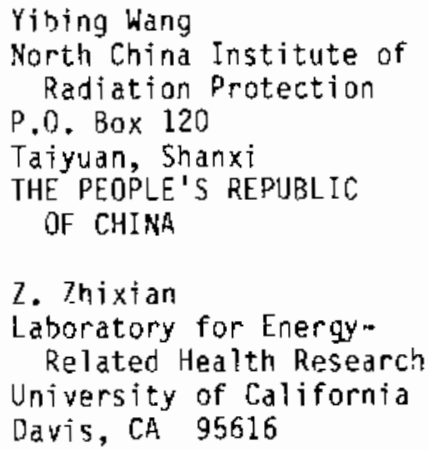

7. 7hixian

Laboratory for Energy. Related Health Research

University of California

Davis, CA 95616

ONSITE

7 DOE Richland Operations office

K. R. Absher

P. K. Clark

D. R. Elle

E. L. Nilson

R. A. Rochette

J. J. Sutey

M. W. Tiernan

2 Hanford Environmental Hea1th

B. D. Breitenstein

R. D. GiTmore 
No. of

Copies

2 Tri-Cities University Center

J. Fimnigan

B. Vallet

Westinghouse Hanford Co.

R. M. Mitchel

117 Pacific Northwest Laboratory

C. C. Ainsworth

R. W. Baalman

J. F. Bagley

W. J. Bair

R. M. Bean

P. A. Beedlow

K. A. Borgeson

L. L. Cadwell

D. A. Cataldo

D. B. Cearlock

T. 0. Chikalla

E. A. Crecelius

J. M. Davidson

B. A. Denovan

D. W. Dragnich

L. L. Eberhardt

C. E. Elderk in

R. A. Elston

R. J. Fellows

J. K. Fredrickson
No. of

Coptes

J. S. Fruchter

T. R. Garland

G. W. Gee

R. A. Gelman

E. S. Gi 1bert

W. A. Glass

M. J. Graham

R. H. Gray

J. M. Hales

P. C. Hays

R. J. Hicks

E. A. Jenne

B. J. Kelman

H. V. Larson

S. F. Li ebetrau

M. W. Ligotke

S. 0. Link

J. A. Mahaffey

R. P. Marshall

J. F. McBride

R. W. Nelson

J. M. Nielsen

C. M. Novich

T. L. Page

J. F. Park

R. W. Perkins

A. M. Platt

L. L. Rader

W. D. Richmond

W. H. Rickard

R. G. Riley (5)

J.T.A. Roberts

L. E. Rogers
No. of

Copies

J. L. Ryan

G. F. Schiefelbein

L. C. Schmid

R. P. Schneider

C. S. Simmons

M. A. Simmons

R. L. Skaggs

J. A. Stott lemyre

J. A. Strand (5)

G. P. Streile

M. F. Sullivan

W. L. Templeton

M. E. Thiede

J. M. Thomas

R. C. Thompson

J. M. Thorp

L. H. Toburen

P. Van Voris

B. E. Vaughan

S. E. Vickerman

J. S. Young

W. C. Weimer

S. G. Weiss

R. E. Wildung $(20)$

L. D. Williams

J. E. York

J. M. Zachara

T. A. Zinn

Life Sciences Library (2)

Publishing Coordination (2)

Technical Report Files (5) 